\title{
Shorter Contributions to Geophysics, 1979
}

GEOLOGICAL SURVEY PROFESSIONAL PAPER 1123-A-D

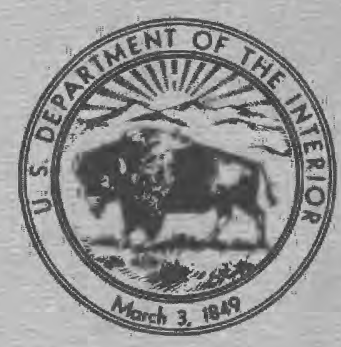




\section{Shorter Contributions}

to Geophysics,

\section{9}

Mountain Breathing-Preliminary Studies of Air-Land Interaction on Mauna Kea, Hawaii

By ALFRED H. WOODCOCK and IRVING FRIEDMAN

Porosity and Density of Kilauea Volcano Basalts, Hawaii

By GORDON R. JOHNSON

Diabase Dikes in the Haile-Brewer Area, South Carolina, and Their Magnetic Properties

By HENRY BELL III, KENNETH G. BOOKS, DAVID L. DANIELS, WILLIIAM E. HUFF, JR., and PETER POPENOE

Aerial Gamma-Ray Survey in Duval, McMullen, Live Oak, and Webb Counties, Texas

By JOSEPH S. DUVAL and KAREN A. SCHULZ

GEOLOGICAL SURVEY PROFESIONAL PAPER $1123-$ A-D

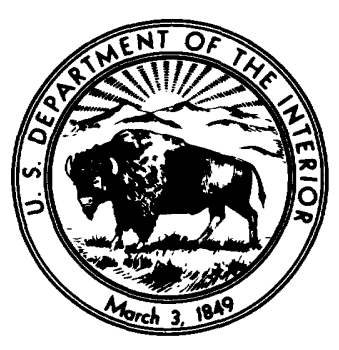

UNITED STATES GOVERNMENT PRINTING, WASHINGTON: 1980 


\section{UNITED STATES DEPARTMENT OF THE INTERIOR}

CECIL D. ANDRUS, Secretary

\section{GEOLOGICAL SURVEY}

H. William Menard, Director

Library of Congress Catalog-card No. 80-600006

For sale by the Superintendent of Documents, U.S. Government Printing Office Washington, D.C. 20402

Stock Number 024-001-03277-5 


\section{CONTENTS}

[Letters designate the separate chapters]

(A) Mountain breathing--preliminary studies of air-land interaction on Mauna Kea, Hawaii, by Alfred H. Woodcock and Irving Friedman.

(B) Porosity and density of Kilaeua Volcano Basalts, Hawaii, by Gordon R. Johnson.

(C) Diabase dikes in the Haile-Brewer area, South Carolina, and their magnetic properties, by Henry Bell III, Kenneth G. Books, David L. Daniels, William E. Huff, Jr., and Peter Popenoe.

(D) Aerial gamma-ray survey in Duval, McMullen, Live Oak, and Webb Counties, Texas, by Joseph S. Duval and Karen A. Schulz. 


\section{CONVERSION FACTORS}

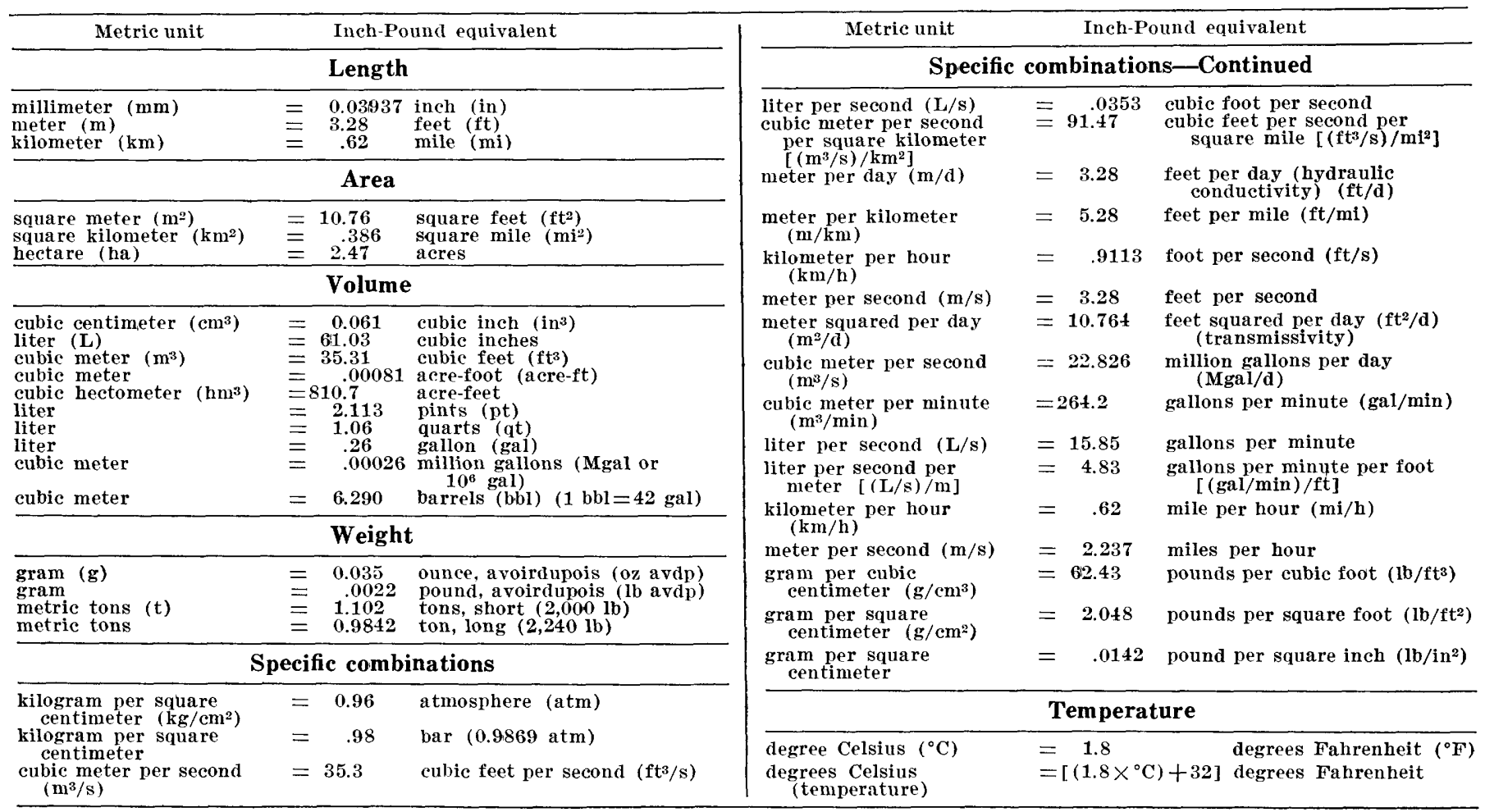


Mountain Breathing-Preliminary Studies of Air-Land Interaction on Mauna Kea, Hawaii

By' ALFRED H. WOODCOCK and IRVING FRIEDMAN

SHORTER CONTRIBUTIONS TO GEOPHYSICS, 1979

GEOLOGICAL SLRVEY PROFESSIONAL PAPER 1123-A

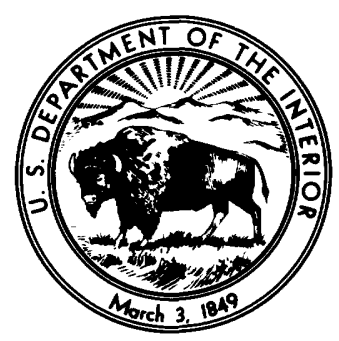





\section{CONTENTS}

Abstract
Introduction
Acknowledgments
Observations
Satent heat loss to the air
$\quad$ Sensible heat of inflowing air as source of latent heat in outflowing air
$\quad$ Conduction of heat into the mountain -
$\quad$ Snow and rainwater as a sensible heat source
Discussion and speculations
Conclusions
References cited -

\section{ILLUSTRATIONS}

FigURE 1. Photograph showing north-northeast view over Mauna Kea summit area

2. Graph showing time-related differences in average direction and volume of airflow in the drill holes, summit cone of Mauna Kea, Hawaii

3. Graph showing temperature versus depth over time in a summit-cone drill hole over a period of about 6 months, Mauna Kea, Hawaii

\section{TABLES}

TABLE 1. Comparative temperature, water vapor, and speeds of motion of air flowing out of the drill hole on the summit cone and in the free air above, Mauna Kea, Hawaii

2. Deuterium in water vapor from 2-liter samples of nearly saturated air flowing from the summit-cone drill

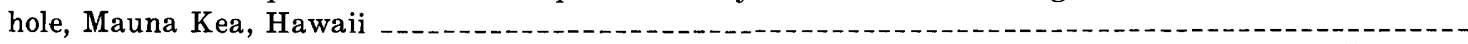

3. Deuterium in snow, graupel, permafrost, and lake waters of the Mauna Kea summit area, Hawaii -..--- 


\title{
MOUNTAIN BREATHING-PRELIMINARY STUDIES OF AIR-LAND INTERACTION ON MAUNA KEA, HAWAII
}

\author{
By Alfred H. Woodcock ${ }^{1}$ and Irving Friedman
}

\begin{abstract}
Air moves in and out of the porous ash and cinder of the summit of the dormant volcano Mauna Kea, Hawaii (altitude about $4200 \mathrm{~m}$ ), presumably in response to pressure changes in the atmosphere. Measurements have revealed an average airflow of about $20 \mathrm{~kg} \mathrm{~m}^{-2} \mathrm{~d}^{-1}$. The air enters the porous ash relatively dry and leaves nearly saturated; the excess water vapor averages about $6.6 \mathrm{gm} \mathrm{kg}^{-1}$. This vapor flow produces an estimated average latent heat loss to the atmosphere from the interior surfaces of the mountain of about $3.9 \mathrm{~W} \mathrm{~m}^{-2}\left(0.94 \mathrm{cal} \mathrm{m}^{-2} \mathrm{~s}^{-1}\right)$. Thus it appears that a sensible heat source, which is probably geothermal, exists within the mountain. A negative thermal gradient in the summit cone and deuterium analyses of exhaled water vapor indicate that the vapor source is, in part, permafrost.
\end{abstract}

\section{INTRODUCTION}

The summit cinder cone on Mauna Kea, Hawaii, is the site of several astronomical observatories of the Institute for Astronomy, University of Hawaii. Figure 1 shows an aerial view of this and other cones which lie well above the moist trade-wind air of the lower atmosphere on the island of Hawaii (lat $19^{\circ} 49^{\prime} 34^{\prime \prime}$ N., long $155^{\circ} 28^{\prime} 20^{\prime \prime}$ W.). Preparatory to the construction of the Mauna Kea observatory buildings in 1967 and 1975, exploratory holes were drilled about $12 \mathrm{~m}$ down into the cinder at the sites. These holes (76 and $100 \mathrm{~mm}$ in diameter) presented an opportunity to obtain the vertical temperature distribution in the summit cone.

In March 1967 the first author visited the first of these holes to make a series of temperature-depth measurements. At the time a rapid flow of air out of the drill hole was noted. This flow was so interesting that the temperature study was delayed and instead measurements were made in the hole of the speed, direction, temperature, and water vapor of the flowing air. Unfortunately the observatory construction

\footnotetext{
${ }^{1}$ Present address is Department of Oceanography, Hawaii Institute of Geophysics, Honolulu, HI 96822.
}

program in 1967 required that the hole be filled after a short time, thus preventing the accumulation of comprehensive amounts of information about the flow.

In 1975 two more drill holes $(100 \mathrm{~mm}$ in diameter and $12 \mathrm{~m}$ deep) in the summit cone were made available for study by the Institute for Astronomy. One was used to continue the airflow (air breathing) study, and the other was used to measure the temperature changes with depth and time. Again the time interval between the drilling and construction at the site was too short to permit conclusive results. However, the combined exploratory data collected during these two intervals are sufficiently interesting and unique to warrant publication now. We hope that the results will lead to a more complete study of the interaction of alpine atmospheres and mountain regions such as the Mauna Kea summit.

The occurrence of pressure-induced breathing of air through porous earth is well established but its role in the transfer of water vapor and latent heat to dry atmospheres remains unexplored. Penetration of air through cave surfaces into porous limestone has been studied (Wigley, 1967), and there is evidence of atmospheric-pressure effect upon watertable levels in soils (Peck, 1960; Turk, 1975). Yen (1963) has done much experimental work on vapor transport through porous snow, and Geiger (1971) reported that moist air adds water to porous dry sandy soils as they breathe about $22 \mathrm{~m}^{3} \mathrm{~m}^{-2} \mathrm{~d}^{-1}$ under the influence of wind-produced pressure changes.

This paper presents the preliminary observations made in the Mauna Kea drill holes and estimates of their meaning in terms of water vapor and latent heat flow from the mountain to the atmosphere. Previous work near the top of Mauna Kea (Wood- 
cock, 1974) revealed a deep layer of permafrost, although the mean air temperature (about $4^{\circ} \mathrm{C}$ ) had been thought to be too high for the occurrence of permafrost there. Also, a negative temperature gradient was found in the sediments under nearby Lake Waiau (fig. 1) (altitude $3970 \mathrm{~m}$ ), a surprising find near the top of a dormant volcano in the tropics (Woodcock and Groves, 1969). Study of the loss of latent heat from the mountain may eventually aid in explaining these anomalous phenomena.

\section{ACKNOWLEDGMENTS}

Lother Ruhnke and Bernard Mendonca of the Mauna Loa observatory, U.S. National Oceanic and Atmospheric Administration, also made a series of measurements of the flow in the Mauna Kea drill holes. These data are included in the average quantities presented in figure 2. We thank the staff of the Institute for Astronomy and the Infra-red Telescope Facility of the University of Hawaii for making the drill holes available. The vane and hot-wire anemometers were loaned to us by C. M. Fullerton and R. C. Taylor of the Cloud Physics Laboratory, Hilo, and the Meterology Department, University of Hawaii, Honolulu, respectively. Kenneth Hardcastle of the U.S. Geological Survey, Denver, Colo., carried out all the deuterium measurements, and R. L. Soroos of the U.S. Geological Survey made the drillhole ash samples available to us. Kerry Wilson of the Cloud Physics Laboratory derived the free-atmosphere mixing-ratio values from the Hilo radiosondes, and Paul Ekern aided our literature search. The gas analyses were carried out under the direc-

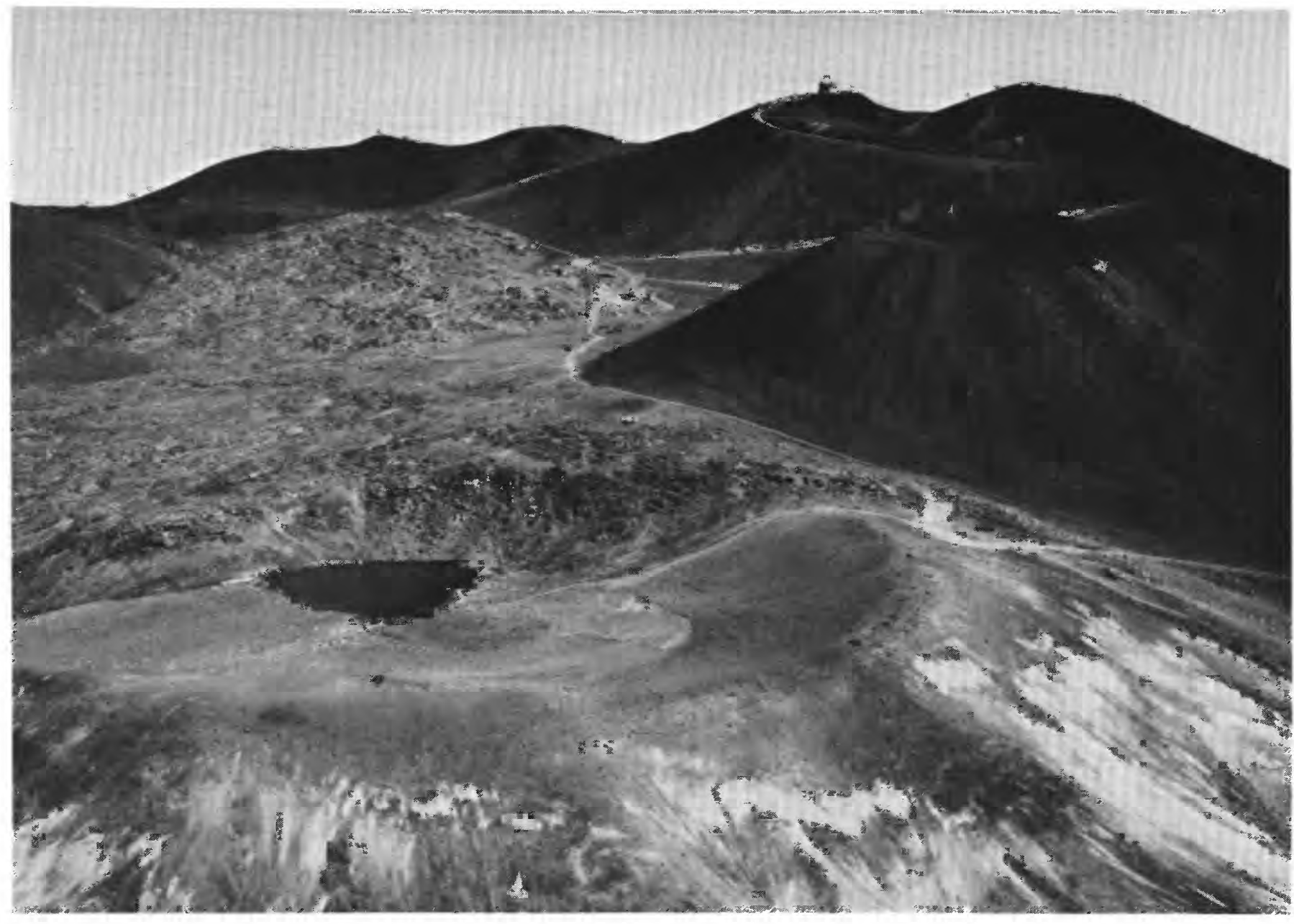

FIgURE 1.-View north-northeast over Mauna Kea summit area, showing some of the many pyroclastic cones there. Waiau Cone and Waiau Lake are in the foreground, and the summit cone, Puu Wekiu, and the observatory of the Institute for Astronomy are in the middle distance to the right. (Photograph by A. J. Abbott.) 
tion of J. J. Naughton, Department of Chemistry, University of Hawaii. G. P. Wollard, recently deceased former Director of the Hawaii Institute of Geophysics, long encouraged and supported the work on Mauna Kea. These studies have been supported in major part by the U.S. Office of Naval Research. Hawaii Institute of Geophysics contribution no. 828.

\section{OBSERVATIONS}

Flow in and out of the holes in the summit cone was measured with a calibrated sensitive Taylor (Biram's type) totalizing vane anemometer with $100-\mathrm{mm}$ inside diameter, which was carefully fitted into the top of the holes for each measurement period. A correction of +12 percent, determined from calibration runs at the Hilo Cloud Physics Observatory, was found to be required when the vane anemometer registered flow into the hole (that is, when the anemometer vane reversed). At airflow rates too low to be registered correctly by the vane anemometer, a hot-wire anemometer was used.

The speed and direction of air motion in the holes was measured for a total of $\mathbf{1 1 1 . 5}$ hours, including two 24-hour periods, during which the mean flow was derived from 274 separate readings. Figure 2 presents an average of the volume and direction of flow per unit of interior surface area of the two drill holes (that is, 2.93 and $3.8 \mathrm{~m}^{2}$ ). The average outflow was $26.9 \mathrm{~m}^{3} \mathrm{~m}^{-2} \mathrm{~d}^{-1}$, derived from the sums of the product of the units of flow and its duration

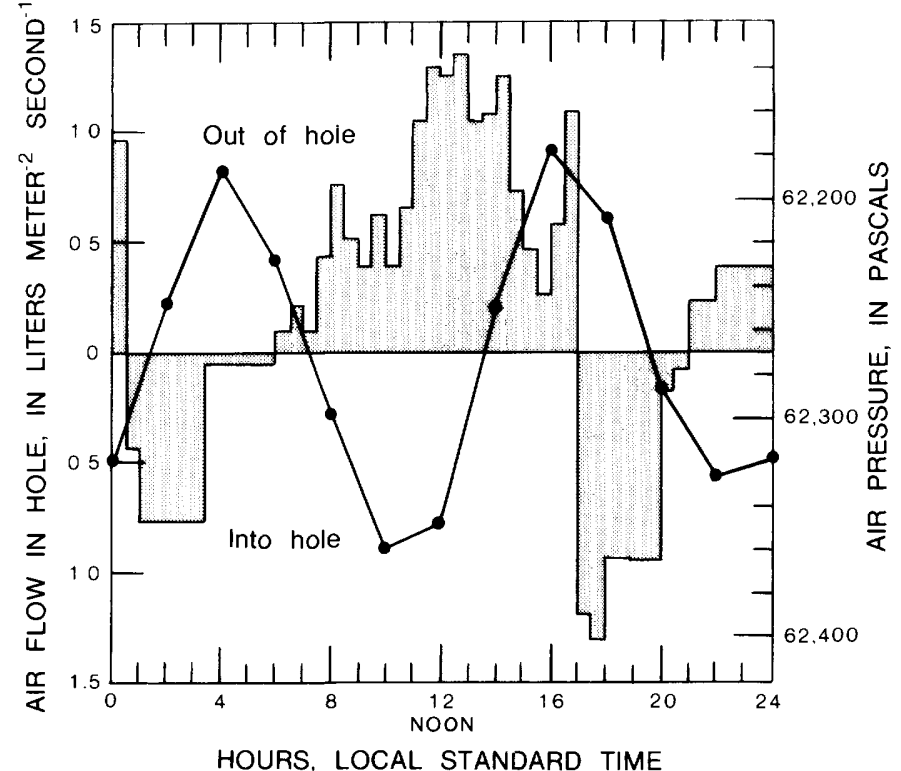

F'IGURE 2.-Time-related differences in average direction and volume of airflow in the drill holes, summit cone of Mauna Kea, Hawaii. In histogram each block represents average volume derived from totalizing anemometer readings during time interval. Black dots show representative semidiurnal air pressures at Mauna Kea observatory.

(fig. 2). This outflow amounts to $21.0 \mathrm{~kg} \mathrm{~m}^{-2} \mathrm{~d}^{-1}$, based upon a mean air density of $0.78 \mathrm{~kg} \mathrm{~m}^{-3}$ at a pressure of 623 millibars (List, 1951, p. 298) or 62,300 pascals.

TABLE 1.-Comparative temperature, water vapor, and speeds of motion of air flowing out of the drill holes on the summit cone and in the free air above, Mauna Kea, Hawaii

$\left[T_{D}\right.$, dry-bulb temperature; $T_{W}$, wet-bulb temberature: $R H$, relative humidity; $W$, mixing ratio; $\sim$, about; $L, 1$ iter $]$

\begin{tabular}{|c|c|c|c|c|c|c|c|c|c|c|c|}
\hline \multirow[b]{2}{*}{$\begin{array}{l}\text { Date and } \\
\text { local standard } \\
\text { time }\end{array}$} & \multicolumn{5}{|c|}{ Free air } & \multicolumn{6}{|c|}{ Out-flowing air } \\
\hline & $\begin{array}{c}\mathrm{T}_{\mathrm{D}} \\
\left({ }^{\circ} \mathrm{C}\right)\end{array}$ & $\begin{array}{c}T_{W} \\
\left({ }^{\circ} \mathrm{C}\right)\end{array}$ & $\begin{array}{c}\mathrm{RH} \\
\text { (percent) }\end{array}$ & $\left(\mathrm{g} \mathrm{kg}^{-1}\right)$ & $\underset{\left(\mathrm{m} \mathrm{s}^{-1}\right)}{\text { Wind }}$ & $\begin{array}{c}\mathrm{T}_{\mathrm{D}} \\
\left({ }^{\circ} \mathrm{C}\right)\end{array}$ & $\begin{array}{c}{ }^{T} W \\
\left({ }^{\circ} \mathrm{C}\right)\end{array}$ & $\begin{array}{c}\text { RH } \\
\text { (percent) }\end{array}$ & (a $\left.{ }^{W} \mathrm{~kg}^{-1}\right)$ & $\begin{array}{l}\text { Flow } \\
\text { volume } \\
\left(\mathrm{L}^{-1}\right)\end{array}$ & $\begin{array}{l}\text { Flow rate } \\
\left(\mathrm{m} \mathrm{s}^{-1}\right)\end{array}$ \\
\hline $\begin{array}{l}\text { May } 5,1967,0920-- \\
\text { July } 25,1967,0830 \\
\text { Auq. } 7,1967,1400- \\
\text { Auq. } 8,1967,0730-\end{array}$ & $\begin{array}{r}3.0 \\
5.4 \\
6.7 \\
.5\end{array}$ & $\begin{array}{r}-1.8 \\
.9 \\
.4 \\
.0\end{array}$ & $\begin{array}{l}27 \\
53 \\
39 \\
93\end{array}$ & $\begin{array}{l}3.1 \\
5.0 \\
4.0 \\
6.2\end{array}$ & $\begin{array}{r}7.2 \\
6.9 \\
4.2 \\
28\end{array}$ & $\begin{array}{l}3.8 \\
4.3 \\
3.6 \\
4.0\end{array}$ & $\begin{array}{l}3.8 \\
4.2 \\
3.6 \\
4.0\end{array}$ & $\begin{array}{r}100 \\
99 \\
100 \\
100\end{array}$ & $\begin{array}{l}8.5 \\
8.7 \\
8.3 \\
8.6\end{array}$ & $\begin{array}{r}5.6 \\
14.1 \\
2.4 \\
3.7\end{array}$ & $\begin{array}{l}0.71 \\
1.8 \\
.3 \\
.5\end{array}$ \\
\hline $\begin{array}{l}\text { Sept. 9, } 1967,1035 \\
\text { Oct. 15, 1975, } 1506 \\
\text { Nov. 18, 1975, } 1240 \\
\text { Nov. 19, 1975, } 1300\end{array}$ & $\begin{array}{l}7.9 \\
5.5 \\
8.2 \\
6.7\end{array}$ & $\begin{array}{l}-1.1 \\
-1.4 \\
-2.6 \\
-1.8\end{array}$ & $\begin{array}{r}18 \\
31 \\
7 \\
20\end{array}$ & $\begin{array}{r}2.0 \\
3.0 \\
.8 \\
2.1\end{array}$ & $\begin{array}{r}8.9 \\
24 \\
23 \\
(1)\end{array}$ & $\begin{array}{l}5.7 \\
7.8 \\
6.7 \\
7.6\end{array}$ & $\begin{array}{l}5.0 \\
7.2 \\
6.6 \\
7.3\end{array}$ & $\begin{array}{l}93 \\
94 \\
99 \\
97\end{array}$ & $\begin{array}{r}9.0 \\
10.5 \\
10.3 \\
10.7\end{array}$ & $\begin{array}{l}2.7 \\
2.3 \\
3.5 \\
3.8\end{array}$ & $\begin{array}{l}.9 \\
.29 \\
.45 \\
.49\end{array}$ \\
\hline $\begin{array}{l}\text { Dec. } 17,1975,1315 \\
\text { Jan. } 21,1976,1150 \\
\text { Jan. 22, 1976, } 1155 \\
\text { Mar. 9, 1976, 1424- }\end{array}$ & $\begin{array}{l}-.4 \\
-3.7 \\
-.2 \\
-.8\end{array}$ & $\begin{array}{l}-5.8 \\
-5.7 \\
-.6 \\
-1.6\end{array}$ & $\begin{array}{l}31 \\
69 \\
94 \\
88\end{array}$ & $\begin{array}{l}1.9 \\
3.4 \\
6.0 \\
6.0\end{array}$ & $\begin{array}{l}3.0 \\
7.0 \\
2.3 \\
3.3\end{array}$ & $\begin{array}{l}6.2 \\
5.0 \\
5.3 \\
5.0\end{array}$ & $\begin{array}{l}5.8 \\
4.7 \\
5.0 \\
5.0\end{array}$ & $\begin{array}{r}95 \\
97 \\
96 \\
100\end{array}$ & $\begin{array}{l}9.5 \\
8.9 \\
9.0 \\
9.2\end{array}$ & $\begin{array}{r}4.7 \\
19.8 \\
6.9 \\
5.3\end{array}$ & $\begin{array}{r}.61 \\
2.53 \\
.88 \\
.68\end{array}$ \\
\hline $\begin{array}{l}\text { Mar. } 10,1976,1520 \\
\text { Apr. } 7,1976,1338- \\
\text { May } 6,1976,1457- \\
\text { May } 7,1976,1428--\end{array}$ & $\begin{array}{r}-3.0 \\
5.8 \\
3.4 \\
2.2\end{array}$ & $\begin{array}{r}-4.4 \\
-3.5 \\
.9 \\
-1.8\end{array}$ & $\begin{array}{l}78 \\
11 \\
72 \\
53\end{array}$ & $\begin{array}{l}4.0 \\
1.1 \\
5.9 \\
4.0\end{array}$ & $\begin{array}{l}9.0 \\
25 \\
7.6 \\
5.2\end{array}$ & $\begin{array}{l}4.8 \\
5.2 \\
6.2 \\
6.2\end{array}$ & $\begin{array}{l}4.6 \\
4.7 \\
5.5 \\
5.5\end{array}$ & $\begin{array}{l}97 \\
94 \\
93 \\
93\end{array}$ & $\begin{array}{l}8.8 \\
8.8 \\
9.3 \\
9.3\end{array}$ & $\begin{array}{l}6.2 \\
6.3 \\
5.6 \\
4.4\end{array}$ & $\begin{array}{l}.79 \\
.80 \\
.72 \\
.56\end{array}$ \\
\hline
\end{tabular}

${ }^{1}$ Near calm. 
A sling psychrometer was inserted into the drill hole during outflow to measure the wet-bulb $\left(T_{\mathrm{w}}\right)$ and the dry-bulb $\left(T_{\mathrm{D}}\right)$ temperatures during the 1967 period (table 1). Because of the relatively low flow rates, the Stevenson Screen hygrometric formulation, adjusted for atmospheric pressure effects, was used to derive relative humidities and mixing ratios (Great Britain Meteorological Office, 1964). However, for all the 1975 and $1976 T_{\mathrm{W}}$ and $T_{\mathrm{D}}$ measurements during outflow in the drill hole, an Assmann ventilated psychrometer was used. The free-air $T_{\mathrm{w}}$ and $T_{\mathrm{D}}$ readings were made from a shielded sling psychrometer. The standard psychrometric formulation (List, 1951, p. 365) was used to derive relative humidity and mixing ratios from the Assmann and sling psychrometer readings.

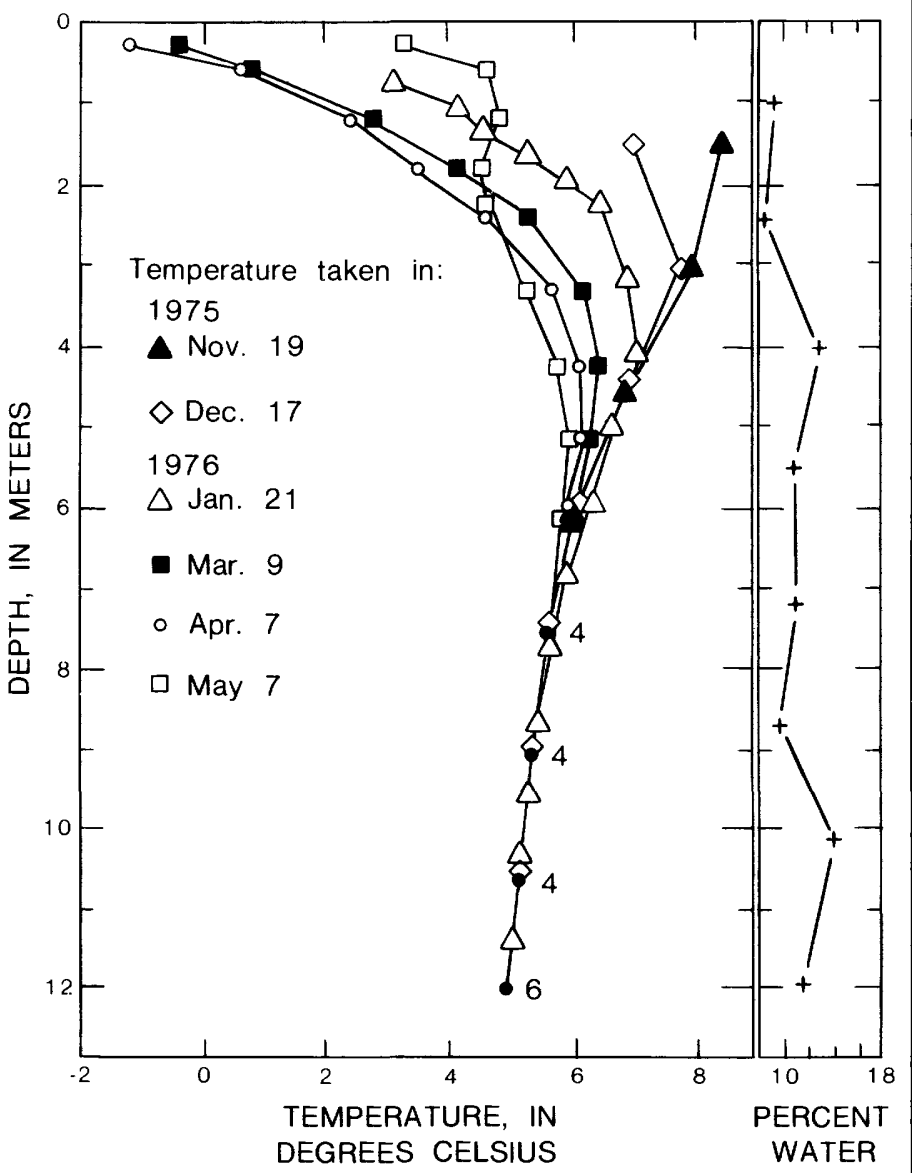

Figure 3.-Temperature versus depth over time in a summitcone drill hole over a period of about 6 months, Mauna Kea, Hawaii. Annual thermal wave not evident below $8 \mathrm{~m}$. To avoid confusion below $7 \mathrm{~m}$, observations at same depth that correspond within $0.1{ }^{\circ} \mathrm{C}$ or less are represented by closed circles. Adjacent digits show number of observations represented by closed circles. Graph at right shows percent water (weight $\mathrm{H}_{2} \mathrm{O}$ /weight dry ash) in drill-hole core samples taken October 15, 1975.
TABLE 2.-Deuterium in water vapor from $2-L$ samples of nearly saturated air flowing from the summit-cone drill hole, Mauna Kea, Hawaii

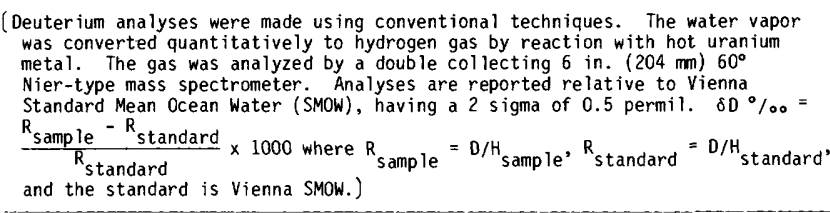

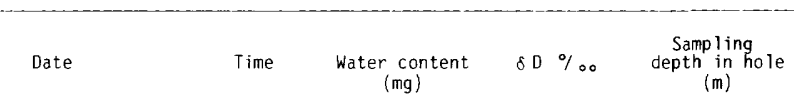

\begin{tabular}{|c|c|c|c|}
\hline $\begin{array}{rr}\text { Dec. } 17,1975-1109 \\
1330 \\
1450\end{array}$ & $\begin{array}{l}13 \\
15 \\
15\end{array}$ & $\begin{array}{l}-177 \\
-174 \\
-182\end{array}$ & $\begin{array}{l}2.5 \\
2.5 \\
2.5\end{array}$ \\
\hline $\begin{array}{rr}\text { Apr. 7. } 1976 & 1049 \\
& 1148 \\
& 1327 \\
1505\end{array}$ & $\begin{array}{l}11.3 \\
13.6 \\
14.1 \\
13.1\end{array}$ & $\begin{array}{l}-156 \\
-159 \\
-159 \\
-163\end{array}$ & $\begin{array}{l}2.5 \\
2.5 \\
2.5 \\
2.5\end{array}$ \\
\hline 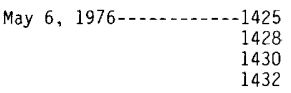 & $\begin{array}{l}16.0 \\
17.2 \\
16.8 \\
16.2\end{array}$ & $\begin{array}{l}-157 \\
-163 \\
-166 \\
-177\end{array}$ & $\begin{array}{r}1.5 \\
3.3 \\
6.1 \\
11.9\end{array}$ \\
\hline
\end{tabular}

Table 1 shows only a part of the numerous psychrometric data used to estimate the net latent heat flow from the holes. For the sake of brevity, the data from which the mean local free-air mixing ratio $\left(2.62 \mathrm{~g} \mathrm{~kg}^{-1}\right)$ was derived are not shown. This mixing ratio is based upon a total of 86 readings of $T_{\mathrm{D}}$ and $T_{\mathrm{w}}$, at least five readings on different days in each month of the year. They included the local free-air mixing ratio $(W)$ values shown in table 1 . The mean local free-air mixing-ratio value is about $1 \mathrm{~g} \mathrm{~kg}^{-1}$ greater than the mean mixing ratio at 4.2 $\mathrm{km}$ in the atmosphere away from the influence of Mauna Kea. This free-atmosphere average was derived from 3 years of twice-daily radiosonde data $(1972,1973,1974)$ at the National Weather Service, Hilo, about $30 \mathrm{~km}$ east of Mauna Kea. Upslope winds during part of the day probably account for this $1 \mathrm{~g} \mathrm{~kg}^{-1}$ increase in water vapor at the Mauna Kea summit (J. Z. Jefferies and D. R. McKnight, written commun., 1968).

The above local air-temperature measurements and those of ground temperature made by thermistor in a third drill hole (fig 3) are corrected, where necessary, for instrumental errors. These errors are discussed in a publication concerning other recent uses of the instruments (Woodcock, 1974).

To learn more about the origins of the water vapor coming from the drill holes, samples for deuterium analysis were taken in 2-L (liter) evacuated stainless steel flasks. A plastic tube, lowered into the hole and drained of surface air during rapid outflow of air, was then attached to the flask valve. While taking the outflow air samples, the valve was 
opened slowly to avoid condensation effects due to rapid pressure changes. The deuterium concentrations of the air samples were measured at a laboratory of the U.S. Geological Survey at Denver, Colo. (table 2).

\section{LATENT HEAT LOSS TO THE AIR}

From the data of figure 2 and table 1 , and the mean local air-mixing ratio (that is, $2.62 \mathrm{~g} \mathrm{~kg}^{-1}$ ), we estimated the average amounts of latent heat coming out of the drill holes. This evaporative heat loss from the interior of the holes $\left(H_{\mathrm{e}}\right)$ is proportional to the mixing-ratio difference $(\Delta W)$, as noted below.

$$
H_{\mathrm{e}}=L(\Delta W M),
$$

where $H_{\mathrm{e}}=$ heat loss in $\mathrm{W} \mathrm{m}^{-2}$ or watts per square meter,

$L=$ latent heat of water vaporization $\left(2.49 \times 10^{6} \mathrm{~J} \mathrm{~kg}^{-1}\right.$ or joules per kilogram) (see footnote 2),

$\Delta W=$ average difference in water-vapor content between entering and exiting air (about $6.6 \mathrm{~g} \mathrm{~kg}^{-1}$ ), and

$M=$ average weight of exiting air (about 21 $\mathrm{kg} \mathrm{\textrm {m } ^ { - 2 }} \mathrm{d}^{-1}$ ).

Using the above relationships, taken from the mean data of table 1 and figure 2, we found that an average of $3.9 \mathrm{~W} \mathrm{~m}^{-2}\left(0.94 \mathrm{cal} \mathrm{\textrm {m } ^ { - 2 }} \mathrm{s}^{-1}\right)$ left the interior surfaces of the drill holes, representing about $137 \mathrm{~g} \mathrm{~m}^{-2} \mathrm{~d}^{-1}$ water (about $50 \mathrm{~mm} \mathrm{yr}^{-1}$ ).

It may seem unreasonable to suggest a mean annual exchange from extrapolation of these few days' observations, because we do not know how representative the quantity may be. However, we believe that it is useful to do so at this exploratory stage in the study, as a flow of dry air in and moist air out as the air pressure changes is almost certainly a long-term fact in this summit region.

\section{SOURCE OF HEAT}

In suggesting that the mountain is the source of the sensible heat represented by the loss of water vapor to the atmosphere, it is necessary to show that other potential sources of heat are inadequate.

SENSIBLE HEAT OF INFLOWING AIR AS SOURCE OF LATENT HEAT IN OUTFLOWING AIR

Transport of sensible heat into the mountain interior due to airflow $\left(H_{*}\right)$ is proportional to the tem-

\footnotetext{
2 This quantity becomes $2.82 \times 10^{\circ} \mathrm{J} \mathrm{kg}^{-1}$ if permafrost proves to be the only vapor source. However, until more is known about the source, we assume the conservative value of $2.49 \times 10^{\circ} \mathrm{J} \mathrm{kg}^{-1}$.
}

perature excess of the inflowing air over that of the outflowing air and is derived as follows:

$$
H_{s}=C_{p}(\Delta T M) \text {, }
$$

where $H_{s}=$ sensible heat transport $\left(\right.$ cal m$\left.^{-2} \mathrm{~d}^{-1}\right)$, $C_{p}=$ specific heat capacity of dry air (about 1004 joules per kilogram kelvin),

$\Delta T=$ temperature excess of inflowing air over outflowing air $\left({ }^{\circ} \mathrm{C}\right)$, and

$M=$ weight of flowing air $\left(21.0 \mathrm{~kg} \mathrm{~m}^{-2} \mathrm{~d}^{-1}\right)$.

Using the above equation, we estimate that the air entering the mountain (that is, $21.0 \mathrm{~kg} \mathrm{~m}^{-2} \mathrm{~d}^{-1}$ ) should have a mean temperature exceeding that of the air leaving the mountain by $16.1^{\circ} \mathrm{C}$ in order to supply the mean latent heat found in the air coming out of the mountain. The average temperature of the exiting air is estimated to be about $5^{\circ} \mathrm{C}$ (table 1 ), which means that the average temperature of the entering air should be about $21^{\circ} \mathrm{C}$. In other words, if the interior of Mauna Kea were dry, the exiting air would have a mean temperature of about $21^{\circ} \mathrm{C}$. Actually, the mean air temperature at the Mauna Kea summit is about $4^{\circ} \mathrm{C}$ (Woodcock, 1974). Thus the sensible heat of the air is an unlikely source of the latent heat in the outflowing air. The fact that airflow into the mountain seems confined to the evening and night hours (fig. 2) when the air is colder (J.Z. Jefferies and D. R. McKnight, written commun., 1968) makes it probable that the air is, on the average, a sink rather than a source of sensible heat.

\section{CONDUCTION OF HEAT INTO THE MOUNTAIN}

Until more is known about the thermal conductivity of the ash, cinder, and lava flows of Mauna Kea summit cones, this source of sensible heat cannot be estimated. However, a brief consideration causes us to conclude that it is almost certainly negligible. Even if we assume that the mountain is solid basalt (thermal conductivity about 0.005 cal $\mathrm{cm}^{-1} \mathrm{~cm}^{-2} \mathrm{~s}^{-1}{ }^{\circ} \mathrm{C}^{-1}$ ), a mean negative temperature gradient of about $2.0^{\circ} \mathrm{C} \mathrm{m}^{-1}$ would be required for conduction to transfer $3.9 \mathrm{~W} \mathrm{~m}^{-2}\left(0.94 \mathrm{cal} \mathrm{m}^{-2}\right.$ $\mathrm{s}^{-1}$ ) into the mountain. A negative gradient is present on the summit cone (fig. 3), but it is only about $0.1^{\circ} \mathrm{C} \mathrm{m}^{-1}$. This is about twice that found under Lake Waiau, where downward heat flow of about

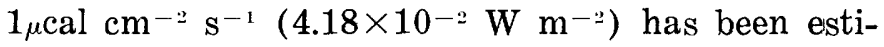
mated (Adams and others, 1976). Actually, the Mauna Kea summit area is made up largely of porous vesiculated ash and cinder, which have a very much lower thermal conductivity than solid basalt. Thus, conduction of sensible heat into Mauna 
Kea is discarded as a source of the latent heat coming out in the air.

\section{SNOW AND RAINWATER AS A SENSIBLE HEAT SOURCE}

The few years of data available indicate that precipitation at the Mauna Kea observatory is only about $250 \mathrm{~mm} \mathrm{yr}^{-1}$, largely in the form of snow. If no evaporation or sublimation occurred at the surface and all this water seeped into Mauna Kea at a temperature of $10^{\circ} \mathrm{C}$, it would carry in less than 10 percent of the heat coming out as latent heat. As melt-water temperatures on Mauna Kea are found to be near $0^{\circ} \mathrm{C}$, it is more likely to be a sink for sensible heat within the mountain than a source.

\section{DISCUSSION AND SPECULATIONS}

The sums of the daily outflow amounts, derived from the product of the average rates and the times in figure 2 , exceed the inflow by a factor of about 1.7. Also, the direction of flow seems to have little if any relationship to the local semidiurnal pressure changes. At this stage in the study we can only assume that these effects are due to horizontal pressure gradients across the summit region and that these gradients are caused perhaps by local differences in winds, air temperature, and summit-cone surface and subsurface conditions. Pyle (1959) has indicated the variability of local diurnal pressures arising from island mountain effects in Hawaii.

In deriving the estimates of average flow in and out of the summit cone, we have simply summed the daily in-and-out flow amounts from the holes and divided by two. Thus, we have assumed that the total inflow and outflow observed (about $53800 \mathrm{~L}$ $\mathrm{m}^{-2} \mathrm{~d}^{-1}$ or liters per square meter per day) occurred generally over the summit cone and that the local inflow deficiency was balanced approximately by a proportional excess of inflow elsewhere on the mountain summit.

In making these estimates of airflow and water vapor flow into and out of the summit cone, we also assumed that the flow through each square meter of the walls of the drill holes was the same as the average flow from a square meter of the mountaintop surface. This may not be a valid assumption, because the porosity of the pyroclastic cones of the summit area probably differs horizontally from place to place, and perhaps vertically as well. (Porter, 1972a, b, discussed the morphology of Mauna Kea cones.) However, we have no reason to think that the area of our drill holes in the summit cone is either more or less porous than elsewhere on the summit cone. In this respect it was encouraging to find that the flow in the second drill hole, about $100 \mathrm{~m}$ from the first, corresponded closely to that in the first hole. However, we are unable to answer the question of whether the flow in these two holes is representative of the average air and vapor motion in and out of the mountaintop. Clearly, more work is required.

The depth of penetration of air into the mountain structures is not known, but the possibilities for internal transport of heat and water via the airpenetration mechanism are apparent. This transport will be a function of differences in the pressure and temperature of the water-saturated air as it moves from place to place within the mountain. The air will extract heat and water vapor from wet, warmer surfaces and will add heat and water to colder surfaces. These exchanges will be superimposed upon adiabatic processes as the air moves up and down. The trend should be one of smoothing out differences in temperature and water distribution within the mountain. (For example note in figure 3 the rather uniform distribution of water despite the preceding 9-month dry period.)

The water-vapor flow out of the summit seems to require a large heat source. We note that the heat loss due to the excess vapor flow $3.9 \mathrm{~W} \mathrm{\textrm {m } ^ { - 2 }}$ $\left(94 \times 10^{-6} \mathrm{cal} \mathrm{cm}^{-2} \mathrm{~s}^{-1}\right)$ is many times the earth's mean geothermal flow in oceanic areas near Hawaii (about 1 or $2 \times 10^{-6} \mathrm{cal} \mathrm{cm}^{-2} \mathrm{~s}^{-1}$ or $4.2-8.4 \times 10^{-2} \mathrm{~W}$ $\mathrm{m}^{-2}$; Lee and Uyeda, 1965 , p. 129). Perhaps it is a heat flow normal for the top of a long-dormant oceanic volcano. (Porter, 1972c, discussed dates of most recent eruptions on Mauna Kea.) Clearly more work of this nature at other locations on Mauna Kea is needed to see how general this latent heat outflow is.

The role of synoptic atmospheric pressure changes in forcing air in and out of the mountain has not been considered. These pressure changes are thought to average only a small fraction of the semidiurnal or diurnal pressure changes in Hawaii mountain locations (Pyle, 1959).

Winds obviously altered the flow of air in the hole, presumably due to their effects on local pressures. The vane anemometer was occasionally observed to reverse direction momentarily, during inflow, as wind gusts passed over the summit cone. The hot-wire anemometer revealed short-prriod variability of 1.5 to 2 times in the speed of flow in or out, as the wind strength changed, but these were 
transitory effects superimposed upon the consistent general flow.

A gas sample was taken from the drill hole during slow outflow at 0800 on August 8, 1967, and later was found to be air. From the data of figure 2, we now know, however, that the air sample should have been taken at the end of the exhalation period, when air with the deepest penetration of the mountain should have been emerging. If subterranean processes (for example, oxidation and degassing) alter the air inhaled, the differences should be most evident in the air emerging near the end of the outflow period.

It is unfortunate that the ground-temperature series (fig. 3) could not have been extended for a full year, in order to show the negative gradient more completely. However, enough of the annual cycle is represented to show that we have probably penetrated below the local depth of near-zero annual amplitude, and that the negative sign is real. At four other locations on Mauna Kea, temperaturedepth measurements taken over more than a year have also shown this near-zero amplitude at depths between 5 and $9 \mathrm{~m}$. Two of these four series of measurements also show a negative gradient.

The hole used for the temperature measurements was drilled on October 14, 1975, without the use of water and apparently without production of much sensible heating. This low level of heating was judged from the fact that the temeprature near the $12-\mathrm{m}$ level was reduced from $5.5^{\circ} \mathrm{C}$, as measured on October 15 , to only $4.9^{\circ} \mathrm{C}$ on November 19 , where it remained practically constant (fig. 3).

The decrease in the deuterium concentration of the water vapor with increasing depth in the hole or with duration of outflow (table 2, April 7 and May 6 observations ${ }^{3}$ ) suggests that the snowmelt is not the source of the lightest water but that the source lies farther down in the mountain. The presence of the negative thermal gradient and of the thick layer of permafrost nearby causes us to think that the source of the lightest vapor is melt from permafrost.

The deuterium of evaporate from melt waters of the known permafrost nearby ( $\delta \mathrm{D}$ or delta deuterium of melt, -88 permil ; Woodcock, 1974) is about -190 permil, and the $\delta \mathrm{D}$ of evaporate from old snowmelt ( $\delta \mathrm{D}$ about -66 permil; Woodcock, 1974) is about - 160 permil (Friedman and others, 1964). The observed $\delta \mathrm{D}$ values of the exhaled vapor fall

\footnotetext{
3 These samples were taken in the presence of slow melting of old snow, whereas the December 17 samples were taken near the end of a 9-month dry period in which only $30 \mathrm{~mm}$ of rain fell at Mauna Kea observatory.
}

TABLE 3.-Deuterium in snow, graupel, permafrost, and lake waters of the Mauna Kea summit area, Hawaii

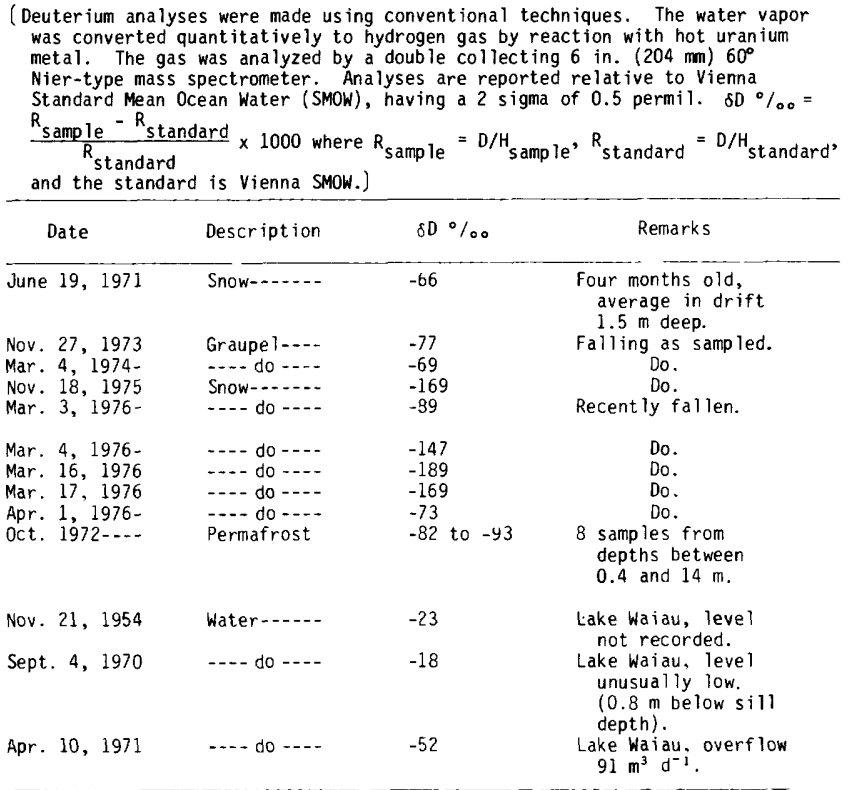

very nearly between these limits (table 2 ), as would be expected if the average vapor source were a mixture of evaporate from old snowmelt and permafrost melt. We assume that fractionation occurs and that the residual (heavier) liquid, from which vaporization has occurred, does not accumulate but drains away to greater depths. The light exhaled vapor might also be explained if the vapor (relative humidity 50 percent) is light when it enters the mountain (that is, $\delta \mathrm{D}=\mathbf{2 5 0}$ permil), and if the $\delta \mathrm{D}$ value of the vapor added by sublimation of permafrost is about -90 permil. The final $\delta \mathrm{D}$ value of the vapor would be about -175 permil. Because measurement of the deuterium of a local air sample from Mauna Kea (Friedman and others, 1964, p. 199-200) revealed the expected relatively heavy value of -160 permil, the preceding explanation is unlikely. Waters from deep within Mauna Kea, originating from low-altitude precipitation, are excluded as a possible vapor source as they are all much heavier (Friedman and Woodcock, 1957).

Four factors incline us to regard permafrost as the most probable source of the light vapor: (1) ice is the only known adequate local source of such light vapor (table 3 ); (2) the $\delta \mathrm{D}$ decreases with depth and duration of outflow, indicating a deeper light-vapor source (table 2); (3) after a long dry summer we found the lightest vapor exhaled (Dec. 17 samples, table 2); and (4) we found a negative temperature gradient in the summit cone (fig. 3). Thus, it appears that deuterium and temperature 
measurements both indicate the presence of permafrost below the observatory site. Extrapolation of the temperature curve below the depth of near-zero annual amplitude (fig. 3) suggests that $0^{\circ} \mathrm{C}$ and ice occur at about $60-\mathrm{m}$ depth.

In the future, with more data available on the average of $\delta \mathrm{D}$ of snow and on the proportions of light and heavy water in the outflowing vapor, we may be able to estimate the rate of melting of the permafrost from the latent heat loss in this vapor.

\section{CONCLUSIONS}

A source of heat in the Mauna Kea summit cone of nearly $4 \mathrm{~W} \mathrm{~m} \mathrm{~W}^{-2}\left(1 \mathrm{cal} \mathrm{\textrm {m } ^ { - 2 }} \mathrm{s}^{-1}\right)$ is indicated by the net outward flow of water vapor due to mountain breathing. Most, if not all, of this heat is apparently derived from within the mountain and not from the atmosphere at the summit. The source of the water vapor appears to be melt from old snow and from permafrost.

\section{REFERENCES CITED}

Adams, W. M., Watts, George, and Mason, George, 1976, Estimation of thermal diffusivity from field observations of temperature as a function of time and depth: Am. Mineralogist, v. 61 , nos. $7-8$, p. 560-568.

Friedman, Irving, and Woodcock, A. H., 1957, Determination of deuterium-hydrogen ratios in Hawaiian waters: Tellus, v. 9, p. 553-556.

Friedman, Irving, Redfield, A. C., Schoen, Beatrice, and Harris, Joseph, 1964, The variation of the deuterium content of natural waters in the hydrologic cycle: Rev. Geophysics, v. 2, no. 1, p. 177-224.
Geiger, Rudolph, 1971, The climate near the ground: Cambridge, Mass., Harvard University Press, $611 \mathrm{p}$.

Great Britain Meteorological Office, 1964, Hygrometric tables, Part II (2d ed.) : London, England, Pub. 265b.

Lee, W. H. K., and Uyeda, Seiya, 1965, Review of heat flow data, Chapter 6 in Terrestrial heat flow: Am. Geophys. Union Geophys. Mon. Ser. No. 8 (Natl. Acad. Sci.-Natl. Research Council Pub. 1288), p. 87-190.

List, R. J., 1951, Smithsonian Meteorological Tables (6th revised ed.) Smithsonian Misc. Colln., v. 114 (pub. 4014), $527 \mathrm{p}$.

Peck, A. J., 1960, The water table as affected by atmospheric pressure: Jour. Geophys. Research, v. 65, no. 8, p. 23832388.

Porter, S. C., 1972a, Buried caldera of Mauna Kea volcano, Hawaii: Science, v. 175 , no. 4029 , p. 1458-1460.

1972b, Distribution, morphology, and size frequency of cinder cones on Mauna Kea volcano, Hawaii: Geol. Soc. America Bull., v. 83, no. 12, p. 3607-3612.

1972c, Holocene eruptions of Mauna Kea volcano, Hawaii: Science, v. 172, no. 3981, p. 375-377.

Pyle, R. L., 1959, The diurnal pressure oscillation on a heated mountain island: Jour. Meteorology, v. 16, no. 5, p. 467482.

Turk, L. J., 1975, Diurnal fluctuations of water tables induced by atmospheric pressure changes: Jour. Hydrology, v. 26, p. 1-16.

Wigley, T. M. L., 1967, Non-steady flow through a porous medium and cave breathing: Jour. Geophys. Research, v. 72, no. 12, p. 3199-3205.

Woodcock, A. H., 1974, Permafrost and climatology of a Hawaii volcano crater: Arctic and Alpine Research, v. 6 , no. 1 , p. 49-62.

Woodcock, A. H., and Groves, G. W., 1969, Negative thermal gradient under alpine lake in Hawaii: Deep-Sea Research, supp. v. 16, p. 393-405.

Yen, Yin-Chao, 1963, Heat transfer by vapor transfer in ventilated snow: Jour. Geophys. Research, v. 68 , no. 4, p. 1093-1101. 


\section{Porosity and Density of Kilauea Volcano Basalts, Hawaii}

By GORDON R. JOHNSON

SHORTER CONTRIBLTIONS TO GEOPHYSICS, 1979

GEOLOGICAL SURVEY PROFESSIONAL PAPER 1123 -B

Tabulation of data and comparison of the densities and porosities of samples

from two depositional environments

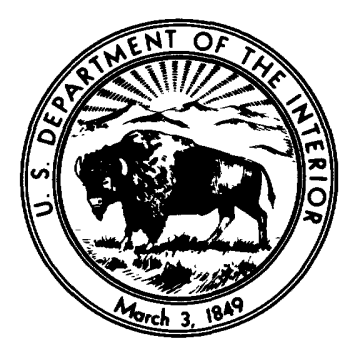





\section{CONTENTS}

Abstract
Introduction
Techniques
Basalts of Kilauea Iki
Basalts of the east rift zone
Summary and conclusions
References cited

\section{ILLUSTRATIONS}

FIgURE 1. Locations of K1-76-1 and HGP-A drill holes, Island of Hawaii

2. Porosities of basalt from drill hole K1-76-1, Kilauea Iki, Hawaii

\section{TABLES}

TABLE 1. Densities and porosities of basalt from Sandia Corporation drill hole K1-76-1, Kilauea Iki, Hawaii ------

2. Densities and porosities of basalt from University of Hawaii drill hole HGP-A, east rift zone of Kilauea Volcano, Hawaii 



\title{
POROSITY AND DENSITY OF KILAUEA VOLCANO BASALTS, HAWAII
}

\author{
By Gordon R. JOHNSON
}

\begin{abstract}
Bulk-density and grain-density measurements were made on samples of basalt from the Kilauea Volcano region of Hawaii. Samples were obtained from two drill holes: a shallow hole at Kilauea Iki pit crater, and a deep hole at the lower east rift zone. Water-accessible porosities were calculated from calipered measurements of bulk density and measurements of grain density made using Archimedes' principle. Helium-accessible porosities were calculated from calipered measurements of bulk density and measurements of grain density made using helium pycnometry. Grain density apparently decreases with depth in the Kilauea Iki drill hole owing to (1) rapid cooling and simultaneous trapping of heavy minerals in the upper material and (2) settling of heavy minerals from the deeper material that was cooled at a much slower rate. No such relationship can be determined from grain-density measurements of east rift zone drill-hole samples. Helium-accessible porosities and corresponding water-accessible porosities of most individual samples from the Kilauea Iki drill hole are nearly the same. In contrast, helium-accessible porosities of many individual samples from the east rift zone drill hole are much greater than corresponding water-accessible porosities. The sample depths involved for the two drill holes and the depositional environments of the rocks probably account for the relationships between helium-accessible porosities and water-accessible porosities determined for one hole differing from those determined for the other.
\end{abstract}

\section{INTRODUCTION}

Sixty-eight samples of Hawaii basalts were collected from cores of two drill holes, one (K1-76 1) in Kilauea Iki pit crater and the other (HGP-A) in the lower east rift zone of Kilauea Volcano (fig. $1)$; both are on the island of Hawaii. Data about the porosity, dry bulk density, and grain density of the samples are tabulated in tables 1 and 2 . The Kilauea Iki samples are tholeiitic basalts from magma deposited in December 1959. The measured Kilauea Iki core samples were collected at 1-m in- tervals from near the ground surface to a depth of $43 \mathrm{~m}$. The samples from the east rift zone drill hole came from cored intervals at depths of 139 to $1965.5 \mathrm{~m}$.

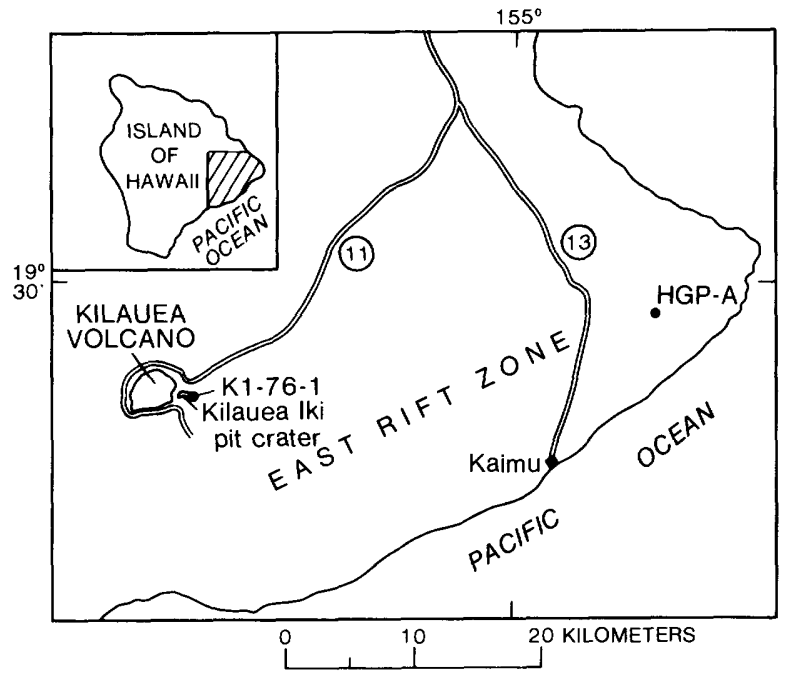

FIgURE 1.-Locations of K1-76-1 and HGP-A drill holes, Island of Hawaii.

\section{TECHNIQUES}

At U.S. Geological Survey laboratories in Denver, Colo., the cores were drilled and trimmed with diamond tools to obtain uniform cylindrical samples $25.4 \mathrm{~mm}$ in both diameter and length. These samples were then dried overnight in a vacuum oven and weighed to an accuracy of $0.001 \mathrm{~g}$. The sample weights, recorded as $W_{d r y}$, were later used to calculate grain volume and grain and bulk densities.

Grain volumes were determined on the small samples using two techniques: (1) helium pycnom- 
etry and (2) the buoyancy, or Archimedes', principle. Basically, helium pycnometer measurements utilize an inert gas to compare the pressure-volume relationship of a sample with that of a steel ball of known volume. Accepting the validity of the perfect gas law with the imposed conditions, the unknown volume of the sample can be derived. Helium is used because it is an inert, nonadsorbing gas and has a small molecular diameter that allows it to penetrate easily into minute sample pores. A method using Archimedes' principle consists of weighing a watersaturated sample suspended from a fine wire and stirrup in a water bath. Before weighing, the samples are soaked in a partial-vacuum environment for several days to attain complete saturation. Grain volume $V_{g}$ is then calculated as

$$
V_{g}=\frac{W_{a r y}-W_{s u b}}{\rho},
$$

where $W_{s u b}$ is the submerged or suspended weight and $\rho$ is the density of water. To obtain grain volumes by either of the above methods assumes that, depending on the method, helium or water completely invades all sample pores.

The bulk volume of a solid consists of the total of the volumes of solid material and of voids. Bulk volumes for these samples were determined by measuring the length and diameter of each cylindrical sample. An average of several readings, each accurate to $0.1 \mathrm{~mm}$, was used to calculate bulk volume. Bulk volumes were also obtained using submerged weights and saturated sample weights. The saturated samples were towelled to a surface-dry condition and weighed in air. Bulk volumes were calculated using the equation

$$
V_{b}=\frac{W_{s a t}-W_{s u b}}{\rho},
$$

where $W_{\text {sat }}$ were saturated surface-dry weights.

Grain and dry bulk densities of the samples were obtained from the volume determinations. Dry bulk density (DBD) was calculated as the ratio of $W_{d r y}$ to the calipered volume, whereas bulk density determined by Archimedes' principle (DBA) was calculated as the ratio of $W_{a r y}$ to $V_{b}$. Grain density was also calculated two ways: (1) the ratio of $W_{d r y}$ to the grain volume obtained by helium pycnometry (SGH) and (2) the ratio of $W_{d r y}$ to $V_{g}$ (SGA).

True measurements of grain volumes, and hence of grain densities, require that all pores are helium or water saturable. If complete saturation is not achieved, then measurements of grain volume will be erroneously large, and apparent grain density will be correspondingly low. In contrast, DBA calculations are not affected by incomplete saturation but rather by the size and quantity of pores that occur at the surface of samples. When saturated samples are removed from water to be weighed in air, the effects of towelling and the low surface tension of water result in all but the very small surface pores becoming unsaturated. Thus $W_{s a t}$ will be reduced, $V_{b}$ will be abnormally low, and DBA will be greater than the actual dry bulk density.

Helium-accessible and water-accessible apparent porosities were determined from measurements of DBD, DBA, SGH, and SGA. Apparent porosity $\left(P_{a}\right)$ is commonly expressed as

$$
P_{a}=100\left(\frac{V_{p}}{V_{b}}\right),
$$

where $V_{p}$ is the volume of fluid-accessible pores and $V_{b}$ is bulk volume. However, because grain volume, measured both by Archimedes' principle and helium pycnometry, includes those pores that are isolated to either water or helium, $V_{p}$ may be expressed as

$$
V_{p}=V_{b}-V_{g} \text {, }
$$

where $V_{g}$ is grain volume.

By substitution,

$$
P_{a}=100\left(1-\frac{V_{g}}{V_{b}}\right),
$$

and expressed in terms of bulk and grain density,

$$
P_{a}=100\left(1-\frac{D_{b}}{D_{l}}\right) \text {, }
$$

where $D_{b}$ is either $\mathrm{DBD}$ or $\mathrm{DBA}$, and $D_{g}$ is either $\mathrm{SGH}$ or SGA. Because values of SGH are nearly the same as intrinsic grain densities in many rock types, helium-accessible porosities in these rocks will approach total porosities. Total porosity may be expressed as

$$
P_{t}=100\left(1-\frac{V_{g}}{V_{b}}\right),
$$

as in equation 5, except that in this case $V_{\eta}$ is the volume of grains only, not that of grains and isolated pores.

In many rocks, such as clean sandstones, wateraccessible porosities are equivalent or nearly equivalent to total porosities, because the interstices between grains are large enough to permit easy penetration by water. In other rocks, such as the basalt from Kilauea Volcano, porosity is controlled mainly by fractures that act as capillaries interconnecting larger vesicular pores. This association of largediameter pores with restricted openings (fractures) 
is one type of so-called inkwell pores. If the fractures are not too restrictive to water penetration, then saturation can be easily achieved by capillarity. However, if the fractures are so tight as to resist water penetration, then saturation can be achieved only if sufficient pressure is applied to overcome the restrictive effects of the surface tension of water. Nevertheless, water-accessible porosities are measured on samples that have been saturated at pressures of about 1 atmosphere, and these porosities may therefore be much less than helium-accessible porosities measured on the same samples. Conversely, the water-accessible porosity of a sample cannot truly be greater than its helium-accessible porosity.

\section{BASALTS OF KILAUEA IKI}

Because of the vesicularity of most of the basalt samples of Kilauea Iki, values of DBA are, for many samples, much greater than corresponding values of $\mathrm{DBD}$. The obviously vesicular samples listed in table 1 have noticeably high values of DBA, but other samples have values of DBA that are as much as $0.09 \mathrm{~g} / \mathrm{cm}^{3}$ greater than corresponding $\mathrm{DBD}$ values. Consequently only DBD was considered when calculating water-accessible porosities, because porosities calculated using values of DBA would be erroneously low and, when compared with heliumaccessible porosities, would lead to the false assumption that most of the basalts of Kilauea Iki have significant quantities of isolated pores. Figure 2 compares the helium-accessible porosities with the water-accessible porosities of the basalt samples of Kilauea Iki. Whereas a direct comparison indicates that porosity as a function of depth is apparently about the same for both types of porosity (fig. $2 A$ ), the ratio of $P_{\mathrm{He}}$ to $P_{\mathrm{H}, \mathrm{O}}$ plotted for all samples (fig. $2 B$ ) shows an interval at 32 to $35 \mathrm{~m}$ where samples have isolated pores and another probably similar zone below a depth of $41 \mathrm{~m}$. Additionally, a single sample at $7 \mathrm{~m}$ has a significant amount of isolated porosity. Otherwise, the helium- and water-accessible porosities are more or less equivalent in these samples.

Because values of SGH for many samples are in the upper range of grain density of basalts (3.1$3.2 \mathrm{~g} / \mathrm{cm}^{3}$ ), helium porosities in these samples are probably about equivalent to total porosities. However, grain density apparently decreases somewhat with depth. This decrease in grain density is probably real but could be due to the effect of porosity that is isolated to both helium and water invasion.
TABLE 1.-Densities and porosities of basalt from Sandia Corporation drill hole K1-76-1, Kilauea Iki, Hawaii

[DBD, dry bulk density using calipered volume; DBA and SGA, dry bulk density and grain density using bulk and grain volume determined from Archimedes' principle; SGH, grain density using volume obtained by helium pycnometry. $\mathrm{P}_{\mathrm{He}}$, helium-accessible porosity, in percent; $\mathrm{P}_{\mathrm{H}_{2} \mathrm{O}}$, water-accessible porosity, in percent. $\mathrm{g} / \mathrm{cm}^{3}=\mathrm{Mg} / \mathrm{m}^{3}$ ]

\begin{tabular}{|c|c|c|c|c|c|c|}
\hline \multirow{2}{*}{$\begin{array}{l}\text { Depth } \\
\text { of core, } \\
\text { in meters }\end{array}$} & $\mathrm{DBD}$ & DBA & SGA & SGH & \multirow{2}{*}{$\begin{array}{l}\mathrm{P}_{\mathrm{He}} \\
100(1\end{array}$} & \multirow{2}{*}{$\begin{array}{c}\mathrm{P}_{\mathrm{H}_{2} \mathrm{O}} \\
\left.-\frac{\mathrm{DBD}}{\mathrm{SGH}}\right), 100\left(1-\frac{\mathrm{DBD}}{\mathrm{SGA}}\right)\end{array}$} \\
\hline & & \multicolumn{3}{|c|}{$-\left(\mathrm{g} / \mathrm{cm}^{3}\right)$} & & \\
\hline $\begin{array}{l}0.99 \\
1.91 \\
2.87 \\
3.73\end{array}$ & $\begin{array}{l}1.860 \\
2.342 \\
2.405 \\
2.342\end{array}$ & $\begin{array}{l}12.359 \\
12.614 \\
12.615 \\
12.558\end{array}$ & $\begin{array}{l}3.046 \\
3.169 \\
3.095 \\
3.147\end{array}$ & $\begin{array}{l}3.144 \\
3.198 \\
3.196 \\
3.197\end{array}$ & $\begin{array}{l}40.8 \\
26.8 \\
24.7 \\
26.7\end{array}$ & $\begin{array}{l}38.9 \\
26.1 \\
22.3 \\
25.6\end{array}$ \\
\hline $\begin{array}{l}4.70 \\
5.59 \\
6.53 \\
7.39\end{array}$ & $\begin{array}{l}2.695 \\
2.655 \\
2.872 \\
2.811\end{array}$ & $\begin{array}{r}12.732 \\
12.770 \\
2.890 \\
2.876\end{array}$ & $\begin{array}{l}3.118 \\
3.056 \\
3.014 \\
3.215\end{array}$ & $\begin{array}{l}3.139 \\
3.109 \\
3.099 \\
3.217\end{array}$ & $\begin{array}{l}14.1 \\
14.6 \\
7.32 \\
12.6\end{array}$ & $\begin{array}{c}13.6 \\
13.1 \\
4.71 \\
12.6\end{array}$ \\
\hline $\begin{array}{r}8.31 \\
9.22 \\
10.13 \\
11.00\end{array}$ & $\begin{array}{l}2.699 \\
2.549 \\
2.678 \\
2.767\end{array}$ & $\begin{array}{r}12.827 \\
12.657 \\
2.745 \\
2.830\end{array}$ & $\begin{array}{l}3.196 \\
3.164 \\
3.208 \\
3.180\end{array}$ & $\begin{array}{l}3.192 \\
3.193 \\
3.235 \\
3.205\end{array}$ & $\begin{array}{l}15.4 \\
20.2 \\
17.2 \\
13.7\end{array}$ & $\begin{array}{l}15.6 \\
19.4 \\
16.5 \\
13.0\end{array}$ \\
\hline $\begin{array}{l}11.96 \\
12.88 \\
13.84 \\
14.71\end{array}$ & $\begin{array}{l}2.416 \\
2.821 \\
2.793 \\
2.789\end{array}$ & $\begin{array}{r}12.566 \\
2.846 \\
2.798 \\
2.811\end{array}$ & $\begin{array}{l}3.158 \\
3.113 \\
3.117 \\
3.104\end{array}$ & $\begin{array}{l}3.192 \\
3.139 \\
3.117 \\
3.119\end{array}$ & $\begin{array}{l}24.3 \\
10.1 \\
10.4 \\
10.6\end{array}$ & $\begin{array}{l}23.5 \\
9.38 \\
10.4 \\
10.7\end{array}$ \\
\hline $\begin{array}{l}15.62 \\
16.56 \\
16.56 \\
17.45\end{array}$ & $\begin{array}{l}2.782 \\
2.248 \\
2.730 \\
2.821\end{array}$ & $\begin{array}{r}2.825 \\
12.578 \\
2.783 \\
2.822\end{array}$ & $\begin{array}{l}3.104 \\
3.035 \\
3.073 \\
3.095\end{array}$ & $\begin{array}{l}3.104 \\
3.055 \\
3.092 \\
3.120\end{array}$ & $\begin{array}{c}10.4 \\
26.4 \\
11.7 \\
9.58\end{array}$ & $\begin{array}{c}10.4 \\
25.9 \\
11.2 \\
8.85\end{array}$ \\
\hline $\begin{array}{l}18.31 \\
19.30 \\
20.57 \\
21.65\end{array}$ & $\begin{array}{l}2.794 \\
2.643 \\
2.655 \\
2.568\end{array}$ & $\begin{array}{l}2.838 \\
2.726 \\
2.706 \\
2.649\end{array}$ & $\begin{array}{l}3.103 \\
3.074 \\
3.025 \\
2.938\end{array}$ & $\begin{array}{l}3.117 \\
3.098 \\
3.053 \\
2.954\end{array}$ & $\begin{array}{l}10.4 \\
14.7 \\
13.0 \\
13.1\end{array}$ & $\begin{array}{l}9.96 \\
14.0 \\
12.2 \\
12.6\end{array}$ \\
\hline $\begin{array}{l}23.24 \\
24.16 \\
25.07 \\
25.96\end{array}$ & $\begin{array}{l}2.451 \\
2.714 \\
2.575 \\
2.758\end{array}$ & $\begin{array}{r}12.638 \\
2.746 \\
12.665 \\
2.790\end{array}$ & $\begin{array}{l}2.994 \\
3.057 \\
3.023 \\
3.008\end{array}$ & $\begin{array}{l}3.013 \\
3.078 \\
3.035 \\
3.052\end{array}$ & $\begin{array}{c}18.7 \\
11.8 \\
15.2 \\
9.63\end{array}$ & $\begin{array}{c}18.1 \\
11.2 \\
14.8 \\
8.31\end{array}$ \\
\hline $\begin{array}{l}27.20 \\
28.32 \\
28.93 \\
29.90\end{array}$ & $\begin{array}{l}2.782 \\
2.751 \\
2.804 \\
2.764\end{array}$ & $\begin{array}{l}2.802 \\
2.764 \\
2.837 \\
2.790\end{array}$ & $\begin{array}{l}3.023 \\
3.027 \\
3.016 \\
3.008\end{array}$ & $\begin{array}{l}3.081 \\
3.054 \\
3.046 \\
3.084\end{array}$ & $\begin{array}{c}9.70 \\
9.92 \\
7.94 \\
10.4\end{array}$ & $\begin{array}{l}7.97 \\
9.12 \\
7.03 \\
8.11\end{array}$ \\
\hline $\begin{array}{l}30.99 \\
32.54 \\
33.45 \\
34.47\end{array}$ & $\begin{array}{l}2.782 \\
2.849 \\
2.867 \\
2.847\end{array}$ & $\begin{array}{l}2.835 \\
2.873 \\
2.880 \\
2.851\end{array}$ & $\begin{array}{l}3.027 \\
2.981 \\
2.991 \\
2.982\end{array}$ & $\begin{array}{l}3.062 \\
3.094 \\
3.092 \\
3.052\end{array}$ & $\begin{array}{l}9.14 \\
7.92 \\
7.28 \\
6.72\end{array}$ & $\begin{array}{l}8.09 \\
4.43 \\
4.14 \\
4.53\end{array}$ \\
\hline $\begin{array}{l}35.38 \\
36.60 \\
37.57 \\
39.04\end{array}$ & $\begin{array}{l}2.788 \\
2.781 \\
2.677 \\
2.645\end{array}$ & $\begin{array}{l}2.802 \\
2.807 \\
2.717 \\
2.714\end{array}$ & $\begin{array}{l}2.972 \\
3.004 \\
2.994 \\
3.024\end{array}$ & $\begin{array}{l}3.044 \\
3.037 \\
3.023 \\
3.050\end{array}$ & $\begin{array}{l}8.41 \\
8.43 \\
11.4 \\
13.3\end{array}$ & $\begin{array}{c}6.19 \\
7.42 \\
10.6 \\
12.5\end{array}$ \\
\hline $\begin{array}{l}39.80 \\
41.17 \\
42.11 \\
43.03\end{array}$ & $\begin{array}{l}2.844 \\
2.877 \\
2.882 \\
2.811\end{array}$ & $\begin{array}{l}2.859 \\
2.894 \\
2.895 \\
2.852\end{array}$ & $\begin{array}{l}2.995 \\
3.013 \\
3.019 \\
2.957 \\
\end{array}$ & $\begin{array}{l}3.007 \\
3.059 \\
3.047 \\
3.038\end{array}$ & $\begin{array}{l}5.42 \\
5.95 \\
5.42 \\
7.47\end{array}$ & $\begin{array}{l}5.04 \\
4.51 \\
4.54 \\
4.94\end{array}$ \\
\hline Averages-- & & & 3.061 & 3.098 & & \\
\hline
\end{tabular}

IDenotes DBA of samples with noticeably large vesicles.

If isolated porosity does in fact exist in samples from greater depth, powdered samples will then exhibit higher values of grain density than will their solid counterparts, because isolated pores are destroyed in the process of pulverization. Nevertheless, the SGH of a powdered split of the $21.65 \mathrm{~m}$ sample was determined to be $2.934 \mathrm{~g} / \mathrm{cm}^{3}$, or nearly the same value as the $\mathrm{SGH}$ of the $21.65 \mathrm{~m}$ solid sample (table 1).

The most probable explanation for the decrease in grain density with depth is that the near-surface lava cooled rapidly, thus trapping heavy minerals, 


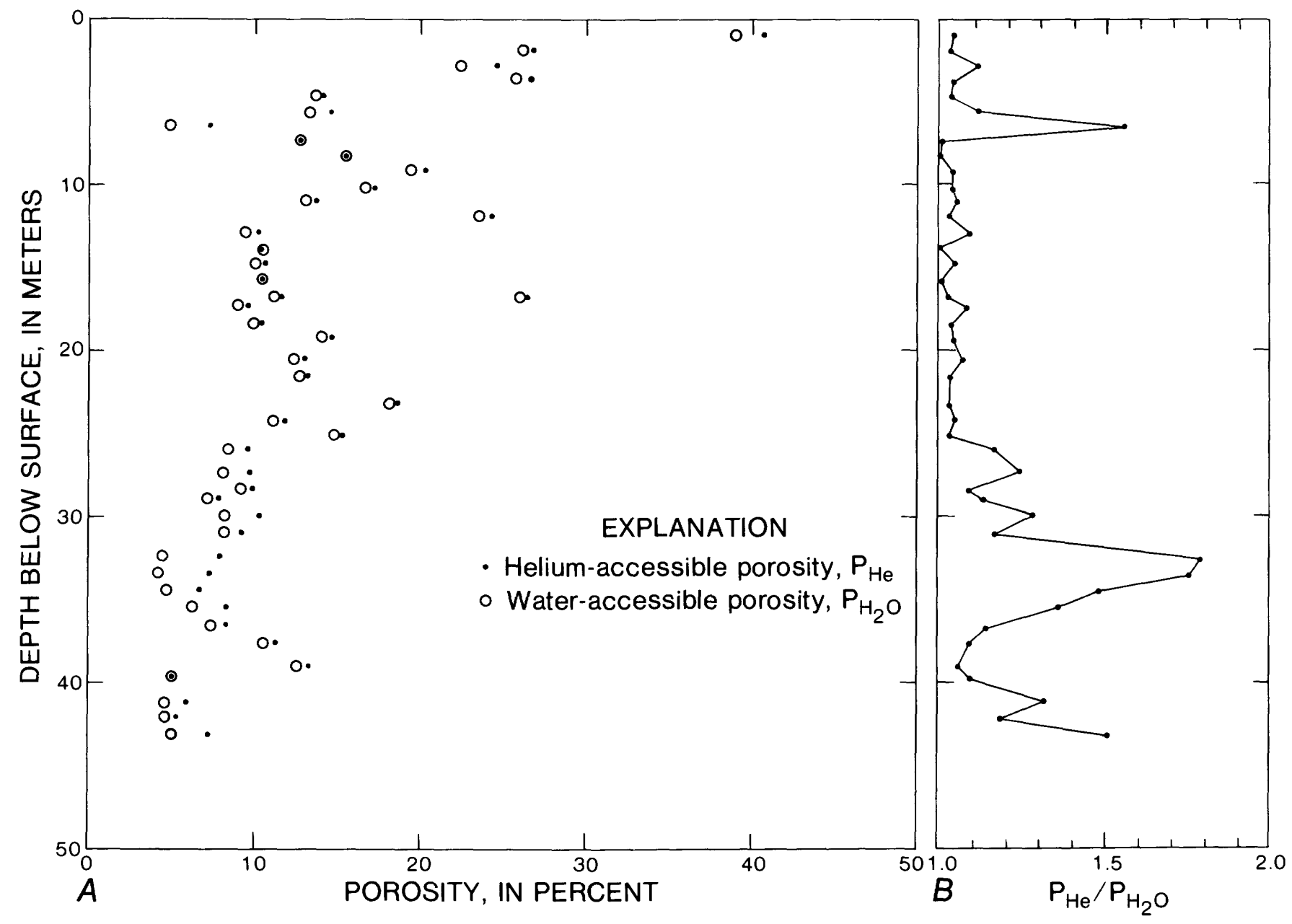

Figure 2.-Porosities of basalt from drill hole K1-76-1, Kilauea Iki, Hawaii. A, Porosity values and their relationship to depth. $B$, Porosity values as a function of technique, showing zones of isolated porosity.

while the deeper lava cooled much more slowly, allowing heavy minerals to settle at some level below the depth of the drill hole. Richter and Moore (1966) reported extreme variability, from 2 to 37 percent, in olivine content in samples from another drill hole at Kilauea Iki; the amount of olivine phenocrysts also affects the chemical composition and results in a corresponding increase in magnesia. Because both olivine and magnesia have specific gravities of about 3.2 , their relative abundance from sample to sample should account for the differences in SGH and SGA values shown on table 1 .

\section{BASALTS OF THE EAST RIFT ZONE}

In contrast with the samples from the Kilauea Iki drill holes, most of the samples from the drill hole on the lower east rift zone are dense, fine-grained basalts. According to Kingston and others (1976), all cores collected below $914.4 \mathrm{~m}$ show some degree of chloritic alteration. Samples taken near the sur- face are normal olivine-bearing tholeiitic basalt. However, none of the samples measured in the laboratory contains large vesicles to the extent that erroneous values of DBA would be expected. Accordingly, most values of DBA are within $0.02 \mathrm{~g} / \mathrm{cm}^{3}$ of their corresponding $\mathrm{DBD}$, and for only one sample, collected from $139.3 \mathrm{~m}$, is the DBA as much as $0.07 \mathrm{~g} / \mathrm{cm}^{3}$ higher than its value of $\mathrm{DBD}$. For these samples either DBD or DBA could be used with comparable results to calculate water-accessible porosity, but to be consistent, only porosities calculated from values of $\mathrm{DBD}$ are shown on table 2 .

Unlike Kilauea Iki samples, porosity-depth relationships and porosity ratios for the east rift zone samples are not graphed, because these samples are from widely spaced cored intervals; thus, the values of porosity do not necessarily represent a continuous function with respect to depth. The ratios of heliumaccessible to water-accessible porosities (table 2) show that at core intervals at depths greater than 
TABLE 2.-Densities and porosities of basalt from University of Hawaii drill hole HGP-A, east rift zone of Kilauea Volcano, Hawaii

[DBD, dry bulk density using calipered volume; DBA and SGA, dry bulk density and grain density using bulk and grain volume determined from Archimedes' principle; SGH, grain density using volume obtained by helium pycnometry. $\mathrm{P}_{\mathrm{He}}$, helium-accessible porosity, in percent; $\mathrm{P}_{\mathrm{H}_{2} \mathrm{O}}$, water-accessible
porosity, in percent. $\left.\mathrm{g} / \mathrm{cm}^{3}=\mathrm{Mg}^{3} \mathrm{~m}^{3}\right]$

\begin{tabular}{|c|c|c|c|c|c|c|c|}
\hline $\begin{array}{l}\text { Depth } \\
\text { cf core, } \\
\text { in meters }\end{array}$ & DBD & DBA & SGA & $\mathrm{SGH}$ & $\begin{array}{l}P_{\mathrm{He}} \\
100\left(1-\frac{D B D}{S G H}\right)\end{array}$ & $\begin{array}{l}\mathrm{P}_{\mathrm{H}_{2} \mathrm{O}} \\
100\left(1-\frac{\mathrm{DBD}}{\mathrm{SGA}}\right)\end{array}$ & $\frac{\mathrm{P}_{\mathrm{He}}}{\mathrm{P}_{\mathrm{H}_{2} \mathrm{O}}}$ \\
\hline $\begin{array}{l}138.99 \\
139.29 \\
139.60 \\
681.23\end{array}$ & $\begin{array}{l}2.810 \\
2.603 \\
2.696 \\
2.546\end{array}$ & $\begin{array}{l}2.838 \\
2.669 \\
2.709 \\
2.538\end{array}$ & $\begin{array}{l}3.038 \\
3.019 \\
3.026 \\
2.837\end{array}$ & $\begin{array}{l}3.046 \\
3.042 \\
3.077 \\
2.949\end{array}$ & $\begin{array}{l}7.74 \\
14.4 \\
12.4 \\
13.7\end{array}$ & $\begin{array}{l}7.50 \\
13.8 \\
10.9 \\
10.3\end{array}$ & $\begin{array}{l}1.03 \\
1.04 \\
1.14 \\
1.33\end{array}$ \\
\hline $\begin{array}{l}682.14 \\
682.29 \\
682.75 \\
876.60\end{array}$ & $\begin{array}{l}2.892 \\
2.908 \\
2.810 \\
2.560\end{array}$ & $\begin{array}{l}2.884 \\
2.893 \\
2.801 \\
2.566\end{array}$ & $\begin{array}{l}2.966 \\
2.964 \\
2.948 \\
2.740\end{array}$ & $\begin{array}{r}12.917 \\
12.909 \\
12.878 \\
2.894\end{array}$ & $\begin{array}{l}0.86 \\
0.03 \\
2.36 \\
11.5\end{array}$ & $\begin{array}{l}2.49 \\
1.89 \\
4.68 \\
6.57\end{array}$ & $\begin{array}{l}0.34 \\
0.02 \\
0.50 \\
1.75\end{array}$ \\
\hline $\begin{array}{r}877.37 \\
1117.55 \\
1118.46 \\
1120.14\end{array}$ & $\begin{array}{l}2.348 \\
2.767 \\
2.614 \\
2.719\end{array}$ & $\begin{array}{l}2.355 \\
2.758 \\
2.615 \\
2.697\end{array}$ & $\begin{array}{l}2.960 \\
2.937 \\
2.910 \\
2.829\end{array}$ & $\begin{array}{r}12.869 \\
3.013 \\
3.041 \\
3.053\end{array}$ & $\begin{array}{l}18.2 \\
8.16 \\
14.0 \\
10.9\end{array}$ & $\begin{array}{c}20.7 \\
5.79 \\
10.2 \\
3.89\end{array}$ & $\begin{array}{l}0.88 \\
1.41 \\
1.37 \\
2.80\end{array}$ \\
\hline $\begin{array}{l}1355.44 \\
1356.97 \\
1358.19 \\
1644.85\end{array}$ & $\begin{array}{l}2.811 \\
2.503 \\
2.666 \\
2.799\end{array}$ & $\begin{array}{l}2.815 \\
2.517 \\
2.663 \\
2.807\end{array}$ & $\begin{array}{l}3.078 \\
2.786 \\
3.138 \\
2.970\end{array}$ & $\begin{array}{r}12.942 \\
2.996 \\
12.995 \\
3.142\end{array}$ & $\begin{array}{l}4.45 \\
16.4 \\
11.0 \\
10.9\end{array}$ & $\begin{array}{l}8.67 \\
10.2 \\
15.0 \\
5.76\end{array}$ & $\begin{array}{l}0.51 \\
1.61 \\
0.73 \\
1.89\end{array}$ \\
\hline $\begin{array}{l}1645.46 \\
1647.14 \\
1838.40 \\
1839.16\end{array}$ & $\begin{array}{l}2.822 \\
2.682 \\
2.883 \\
2.856\end{array}$ & $\begin{array}{l}2.816 \\
2.688 \\
2.866 \\
2.843\end{array}$ & $\begin{array}{l}2.980 \\
2.914 \\
2.945 \\
2.948\end{array}$ & $\begin{array}{l}2.983 \\
2.981 \\
3.003 \\
3.096\end{array}$ & $\begin{array}{c}5.40 \\
10.0 \\
4.00 \\
7.75\end{array}$ & $\begin{array}{l}5.30 \\
7.96 \\
2.11 \\
3.12\end{array}$ & $\begin{array}{l}1.02 \\
1.26 \\
1.90 \\
2.48\end{array}$ \\
\hline $\begin{array}{l}1839.32 \\
1840.08 \\
1964.89 \\
1965.50\end{array}$ & $\begin{array}{l}2.826 \\
2.843 \\
2.397 \\
2.418\end{array}$ & $\begin{array}{l}2.826 \\
2.865 \\
2.385 \\
2.411\end{array}$ & $\begin{array}{l}2.953 \\
2.954 \\
2.960 \\
2.946\end{array}$ & $\begin{array}{l}3.122 \\
2.991 \\
3.067 \\
2.971\end{array}$ & $\begin{array}{c}9.48 \\
4.94 \\
21.8 \\
18.6\end{array}$ & $\begin{array}{c}4.30 \\
3.76 \\
19.0 \\
17.9\end{array}$ & $\begin{array}{l}2.20 \\
1.31 \\
1.15 \\
1.04\end{array}$ \\
\hline
\end{tabular}

${ }^{1}$ Denotes SGH of samples with noticeably large vesicles.

$139.60 \mathrm{~m}$, water-accessible porosity is, in most samples, much less than helium-accessible porosity. Only samples collected from the core interval at about $139 \mathrm{~m}$, a single sample at $1645.46 \mathrm{~m}$, and those at $1964.89 \mathrm{~m}$ and $1965.50 \mathrm{~m}$, near the bottom of the drill hole, have nearly equivalent water-accessible and helium-accessible porosities.

Unfortunately, reliable SGH measurements could not be made on those samples that are footnoted in table 2. Unstable and nonreproducible instrument readings indicated that the permeabilities of the samples were so tight that they resisted invasion by helium. However, these same samples were apparently more water saturable than helium saturable, because their SGA values in all cases were greater than their corresponding SGH values. Paradoxically, accurate values of SGH must always be equal to or greater than corresponding values of SGA.

According to the Hawaii Geothermal Project Well Completion report HGP-A (Kingston and others, 1976), all samples collected below $366 \mathrm{~m}$ to a depth of $1219 \mathrm{~m}$ contain secondary zeolites that are moderately abundant. One possible explanation for the obviously low SGH values of the samples footnoted in table 2 is that certain zeolites act as molecular sieves (Evans (1964), among others) and thereby are permeable to small molecules in such a way that excess amounts of helium would be held in the crystal lattices. Thus, when measured on these samples, grain volumes could be larger than actual 
grain volumes, and values of SGH would be correspondingly low.

This explanation assumes the mineralogy of the zeolite to be that which would act as a molecular sieve to helium molecules. If so, then this type of zeolite is in significant abundance in three core intervals: (1) from 681.23 to $682.75 \mathrm{~m}$, (2) from 876.60 to $877.37 \mathrm{~m}$, and (3) from 1355.44 to 1358.10 $\mathrm{m}$. Obviously, helium-accessible porosities are much tolo low in all the footnoted samples from these three core intervals, and it is possible, although indeterminable, that the values of SGH for other samples taken from these intervals are also erroneous. Because values of SGH for such samples from these core intervals cannot be relied on, helium-accessible porosities must be considered therefore to be erroneously low.

\section{SUMMARY AND CONCLUSIONS}

The porosity relationships graphed in figure $2 B$ show that the fractures in the basalt of Kilauea Iki are, for the most part, open and accessible to water penetration. The few samples that exhibit wateraccessible porosity that is anomalously low compared with helium-accessible porosity might represent layers of basalt that have tight fractures, although under an increased hydrostatic pressure these fractures could be open to water penetration. In contrast, many samples from the drill hole at the east rift zone have porosities that are isolated to water penetration. Most of the tight east rift zone lavas are presumed to have been formed subaerially (Kingston and others, 1976), whereas the lavas of Kilauea Iki were formed at or near ground surface.

A general decrease in grain density with depth indicated by the Kilauea Iki samples is probably due to a near-surface concentration of heavy minerals and possibly to a settling and depletion of heavy minerals in the deeper zones. No such relationship is evident from grain density measurements of samples from the east rift zone drill hole.

\section{REFERENCES CITED}

Evans, R. C., 1964, An introduction to crystal chemistry: Cambridge, Cambridge University Press, 410 p.

Kingston, Reynolds, Thom, and Allardice, Ltd., 1976, Hawaii geothermal project well completion report HGP-A : Honolulu, University of Hawaii Research Corp., and U.S. Energy Research and Development Administration, $34 \mathrm{p}$.

Richter, Donald H., and Moore, James G., 1966, Petrology of the Kilauea Iki lava lake, Hawaii: U.S. Geological Survey Professional Paper 537-B, p. B1-B26. 


\section{Diabase Dikes in the Haile-Brewer Area, South Carolina, and Their Magnetic Properties}

By HENRY BELL III, KENNETH G. BOOKS, DAVID L. DANIELS, WILLIAM E. HUFF, JR., and PETER POPENOE

SHORTER CONTRIBUTIONS TO GEOPHYSICS, 1979

GEOLOGICAL SURVEY PROFESSIONAL PAPER 1123 -C

Paleomagnetic poles are calculated for

Upper Triassic and Lower Jurassic dikes

revealed by magnetic data

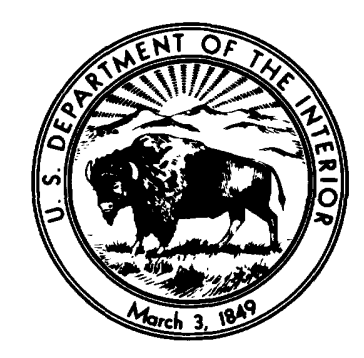





\section{CONTENTS}

Abstract
Introduction
Magnetic setting
Geologic setting
$\quad$ Diabase dikes
Sampling procedures
Laboratory procedures
Results -
Conclusions
References cited

\section{ILLUSTRATIONS}

Figure 1. Sketch map of the Appalachian region of the Eastern United States, showing the location of the HaileBrewer area, South Carolina, known occurrences of dikes of Triassic and Jurassic age, and areas of outcrop of the Newark Group

2. Aeromagnetic map of the Camden-Kershaw area, north-central South Carolina

3. Geologic map of the Haile-Brewer area, South Carolina

4. Profiles obtained by means of an airborne magnetometer carried at $122-\mathrm{m}$ elevation and profiles obtained by means of a truck-mounted magnetometer

5. Two-dimensional magnetic profiles of a simulated geologic profile calculated for $4.6 \mathrm{~m}$ and $122 \mathrm{~m}$ elevation

\section{TABLES}

TABLE 1. Major- and minor-oxide composition, trace-element content, and normative mineralogy of a large diabase dike. Lancaster County, S.C.

2. Magnetic properties and normative magnetite and ilmenite contents of a large diabase dike, Lancaster County, S.C.

3. Definition of terms used in the sampling hierarchy

4. Results of spinner-magnetometer measurements on specimens of diabase dikes from the Haile-Brewer area, South Carolina, untreated and after cleaning by subjection to alternating magnetic fields of intensities of 100,200 , and 300 oersteds

5. Paleomagnetic directions and paleomagnetic pole positions for diabase dikes and dike swarms in the Haile-Brewer area, South Carolina

6. Summary of magnetic data and paleomagnetic pole positions for diabase dikes and dike swarms in the Haile-Brewer area, South Carolina 

SHORTER CONTRIBUTIONS TO GEOPHYSICS, 1979

\title{
DIABASE DIKES IN THE HAILE-BREWER AREA, SOUTH CAROLINA, AND THEIR MAGNETIC PROPERTIES
}

\author{
By Henry Bell III, Kenneth G. Books, David L. Daniels, \\ William E. Huff, Jr., and Peter Popenoe
}

\begin{abstract}
The aeromagnetic map of the Haile-Brewer area, eastcentral South Carolina, shows numerous strong narrow northwest-trending anomalies that are associated with diabase dikes. These diabase dikes were sampled by means of core-drilling equipment to obtain oriented samples on which magnetic properties were measured for paleomagnetic orientation. The pole positions calculated for the various dikes are in two groups that are close together but that have opposing polarity. The paleomagnetic pole positions calculated are within the range of those obtained from diabase intrusive rocks in eastern North America that are considered to be Late Triassic and Early Jurassic in age.
\end{abstract}

\section{INTRODUCTION}

Sedimentary and igneous rocks of the Newark Group (Upper Triassic and Lower Jurassic) in the Eastern United States crop out in extensively faulted narrow basins. The igneous rocks are predominantly diabase and gabbro that have been emplaced as dikes and sills. Commonly, the diabase dikes are emplaced in faults cutting not only fossiliferous sedimentary rocks within the basins but also, as in the Haile-Brewer area, South Carolina, Paleozoic or Precambrian crystalline rocks in areas widely distributed beyond the basins, as P. B. King has emphasized $(1961,1971)$. The igneous rocks, including the diabase dikes, that are in these basins have been much studied, particularly in regards to their petrography, structural setting, and relation to the rifting that preceded continental drift and the opening of the Atlantic Ocean.

In West Africa, particularly Mauritania and Liberia, and in northern South America, in Brazil, Guyana, Surinam, and French Guiana, there are diabase dikes and dike swarms very similar in appearance and probably in age to the widespread diabase dikes in eastern North America. P. R. May
(1971, fig. 1) has pointed out that the orientation of all these dikes is such that if the continents surrounding the Atlantic Ocean were restored to a precontinental-drift configuration, these widely separated dikes would all seem to radiate from a common center located somewhere near the southeast coast of the United States and perhaps on the Blake Plateau.

In the Eastern United States, particularly in Pennsylvania, these diabase intrusive rocks are associated with deposits of iron, copper, and other minerals, but the relation of the diabase to the mineralizing process is obscure. In the Haile-Brewer area, South Carolina, diabase dikes cut gold-bearing rocks but appear to be younger than the mineralizing processes. Although the diabase dikes are not known to be related to the mineralization in South Carolina, they are nevertheless part of the geologic environment where investigations into the geologic, geochemical, and geophysical setting of the gold mines have been carried out.

Aeromagnetic data indicate that the dikes are even more abundant and widespread than previously believed from geologic reconnaissance mapping of mining areas. They may indicate areas of abundant pre-Mesozoic fracturing, or perhaps other features, as yet unrecognized, that might lead to favorable areas for ore deposits. Paleomagnetic studies offer a method for placing the diabase dikes in the HaileBrewer area more precisely into the context of the geologic and chronologic framework of Mesozoic rocks in eastern North America. For this purpose, many of the dikes have been sampled, and their magnetic properties and paleomagnetic-pole positions have been obtained. The results are summarized in this report. Figure 1 shows the location of 


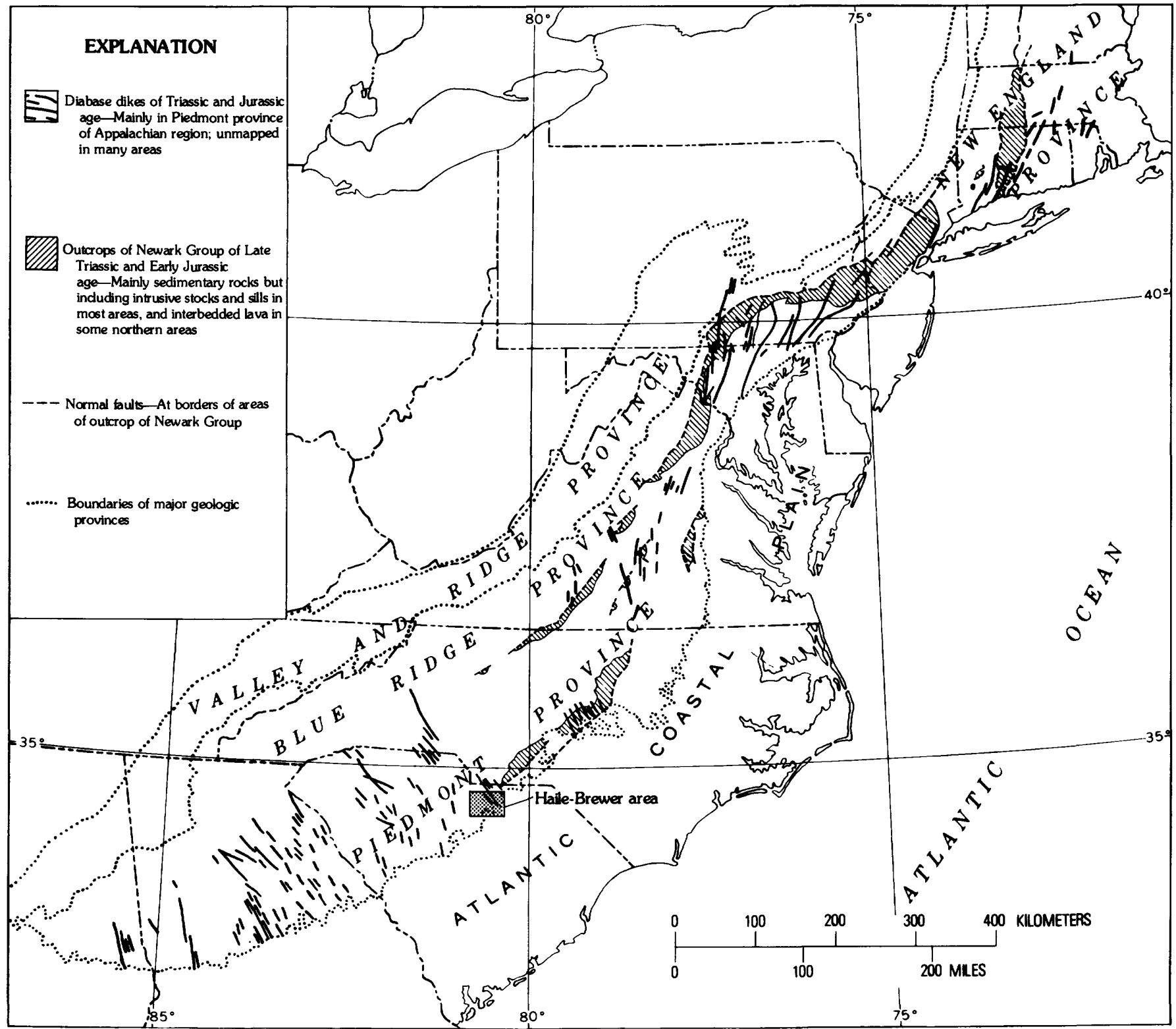

Figure 1.-Sketch map of the Appalachian region of the Eastern United States, showing the location of the Haile-Brewer area, South Carolina, known occurrences of dikes of Triassic and Jurassic age, and areas of outcrop of the Newark Group. (Modified from King 1961.)

the Haile-Brewer area in South Carolina, the wide distribution of diabase dikes in the Appalachian region, and areas where the dikes cut sedimentary rocks of Late Triassic and Early Jurassic age.

\section{MAGNETIC SETTING}

A total-intensity magnetic map of part of South Carolina, including the area of the Haile and Brewer mines, is shown in figure 2 , which is modified from a map by the U.S. Geological Survey (1970). The data were acquired by means of airborne instru- ments along flight traverses that were about $122 \mathrm{~m}$ above the ground, approximately $0.8 \mathrm{~km}$ apart, and oriented east and west. The Doppler system was used for navigational location. The data, contoured relative to an arbitrary datum, show the totalintensity magnetic field in gammas.

The aeromagnetic map (fig. 2) shows numerous areas of anomalies that are closely spaced, moderately high in amplitude, linear, and positive; the anomalies reflect sharp, narrow variations in the intensity of the Earth's magnetic field. Many of 
these linear positive anomalies are conspicuously alined, trend northwest, and have steep gradients that reflect sources having tops near the surface of the ground. The anomalies are clearly related to diabase dikes that crop out in the area. The flight lines trending approximately due east are particularly well oriented for revealing these narrow, linear magnetic anomalies. If the flight lines had been oriented parallel to the anomalies, their recognition would have been much more difficult for several reasons; for example, the anomalies might have been between flight lines and might not have been recorded, or the large differences in magnetic response between adjacent flight lines might have been interpreted as an instrumental or other technical difficulty.

The steep northwest-trending anomalies are not evident either on the northwest part of the map or on the southeast part. In a large part of the area shown on the magnetic map (fig. 2) centered near lat $34^{\circ} 30^{\prime} \mathrm{N}$., long $80^{\circ} 45^{\prime} \mathrm{W}$., the level of magnetic intensity is so great that the magnetic contrast due to the linear anomalies is lost. The geologic map of the Haile-Brewer area shows that the Liberty Hill quartz-monzonite pluton is in this area (fig. 3) and that it is cut by diabase dikes, at least locally and in the peripheral parts of the pluton. Apparently the magnetic intensity of the quartz monzonite is nearly the same as that of the diabase dikes. The highintensity magnetic anomalies in the southeastern part of the map area near lat $34^{\circ} 15^{\prime} \mathrm{N}$., long $80^{\circ} 37^{\prime}$ $30^{\prime \prime} \mathrm{W}$. also obscure the dike anomalies. There, broad northeast-trending anomalies coincide with a steep gradient in gravity data and may reflect faulting in subsurface rocks (Popenoe and Bell, 1975). Strong linear northwest-trending magnetic anomalies have been recognized southeast of the area shown in figure 2; these anomalies have been interpreted as reflecting diabase dikes deeply buried beneath Coastal Plain sedimentary rocks (Popenoe and Zietz, 1977).

The widths of the northwest-trending linear aeromagnetic anomalies indicate tabular magnetic sources, which are inferred to be wider or less steeply dipping than field experience and reconnaissance mapping show the diabase dikes to be. In order to locate the magnetic anomalies as precisely as possible on the ground and to confirm that the anomalies overlie diabase dikes, as inferred, a ground-magnetometer survey was made using truckmounted equipment. Traverses were made along roads that crossed the anomalies shown by the airborne survey. The equipment, described by Zablocki (1967), consists of an encapsulated flux-gate mag- netometer suspended from 3 to $4.6 \mathrm{~m}$ above the ground on a boom behind the vehicle. Kane, Harwood, and Hatch (1971) used similar equipment in New England to test and map magnetic anomalies previously located by airborne surveys.

The results of the ground traverses in South Carolina were similar to the results in New England and indicated that the sources of several anomalies were diabase dikes not previously discovered. In addition, the ground traverses showed that in a few places where data from airborne instruments indicate a broad anomaly, the ground traverse shows many small anomalies not evident in the data from the airborne survey (fig. 4). These smaller anomalies in the ground data commonly seem to result from closely spaced thin dikes, which are not indicated as individual anomalies in data from the airborne-magnetometer survey. In Meriwether County, Ga., a single linear magnetic anomaly detected by airborne methods proved to be as many as four distinct diabase dikes when studied at ground level (Rathe and Long, 1975). In New England, Kane and others (1971) found that airborne equipment could not detect single rock units having thicknesses of less than about $15 \mathrm{~m}$.

By means of a two-dimensional technique, magnetic profiles were calculated to test the assumptions that broad magnetic anomalies result from closely spaced thin dikes; a small part of profile $A-A^{\prime}$ in figure 4 was used as a model. The model, shown in figure 5, consists of tabular bodies simulating diabase dikes ranging from 7.6 to $30.5 \mathrm{~m}$ in thickness, extending an infinite length perpendicular to the profile, dipping at $80^{\circ} \mathrm{W}$. or $80^{\circ}$ E., extending to an infinite depth, and having parallel contacts. The magnetic properties used to calculate the profiles were chosen to be representative of all the known diabase dikes in the Haile-Brewer area and were in some cases averages of as many as 37 dikes. Two profiles were calculated, at $4.6 \mathrm{~m}$ above the ground and at $122 \mathrm{~m}$, and they were compared with the observed profiles obtained from the airborne and truck-mounted magnetometers.

The results, illustrated in figure 5, show calculated profiles that resemble closely the observed profiles. The results suggest that many of the linear magnetic anomalies shown on the aeromagnetic map (fig. 2) likewise may represent an unknown number of dikes of various thicknesses and spacings, all trending at any particular location in nearly the same direction. On the aeromagnetic map (fig. 2), all the anomalies that have identifiable diabase-like outcrops are shown as a dike or dike swarm. In 


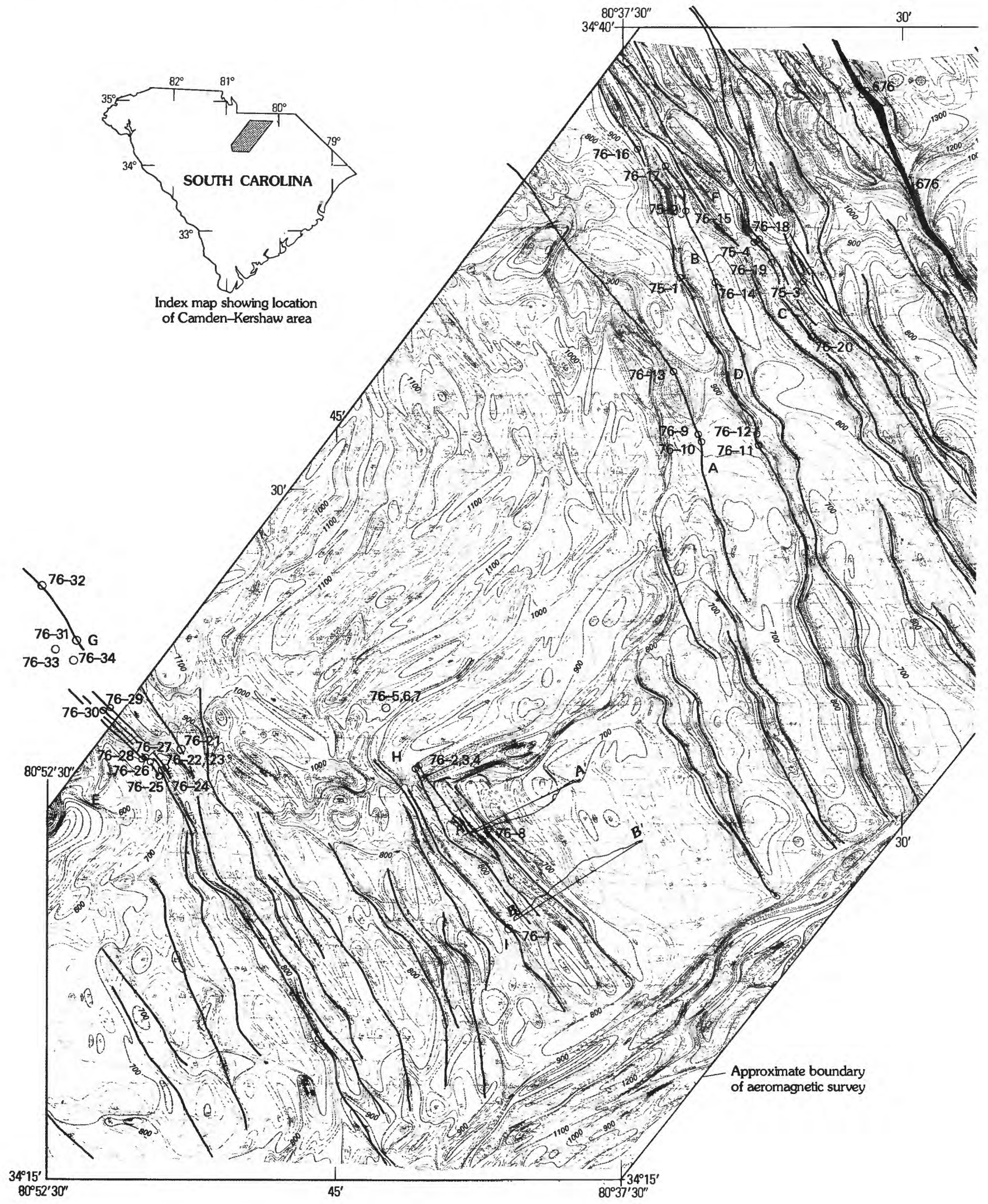

FIGURE 2.-Aeromagnetic map of the Camden-Kershaw area, north-central South Carolina. (Modified from U.S. Geological Survey, 1970.) 

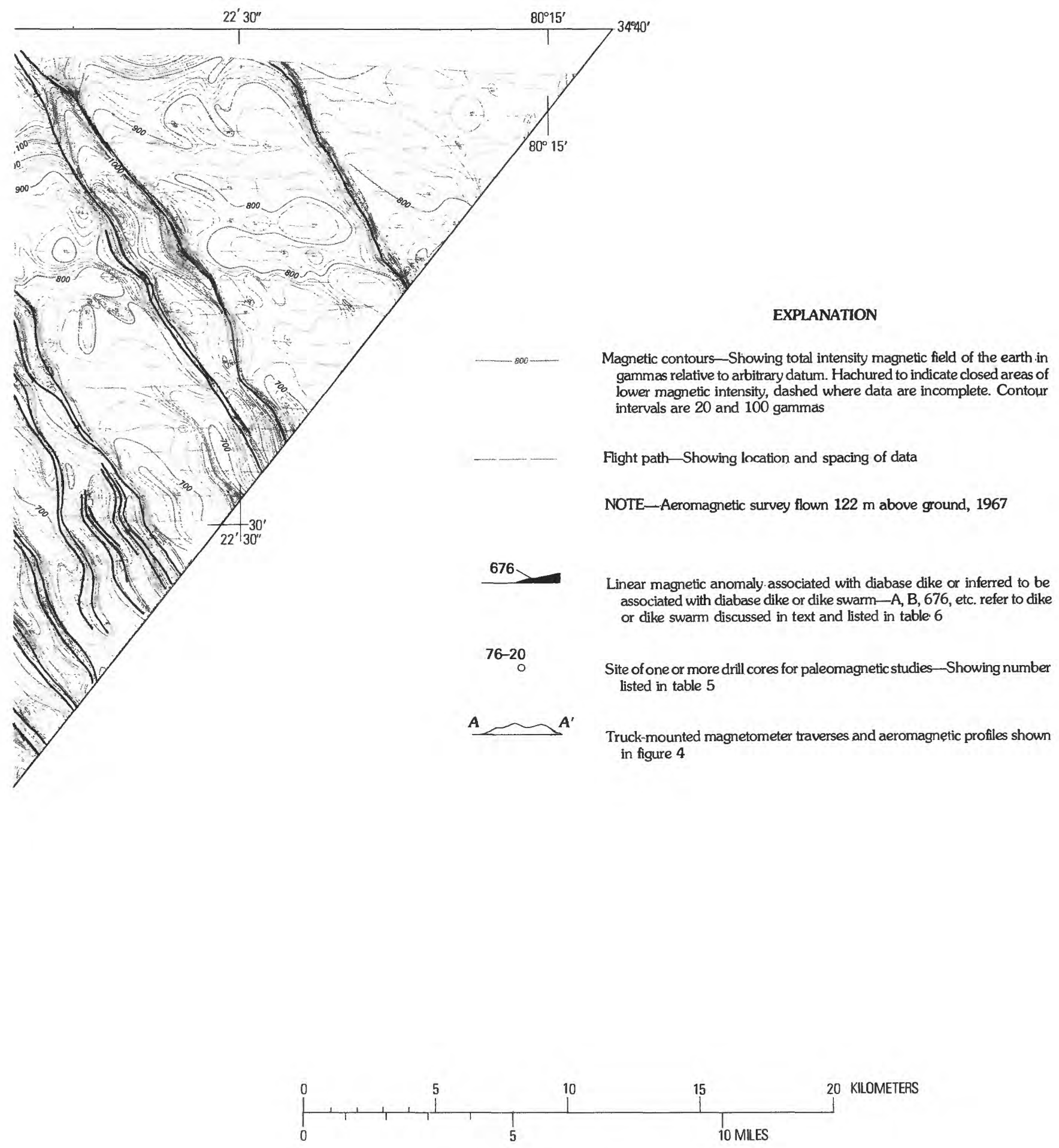

Frgure 2.-Continued. 


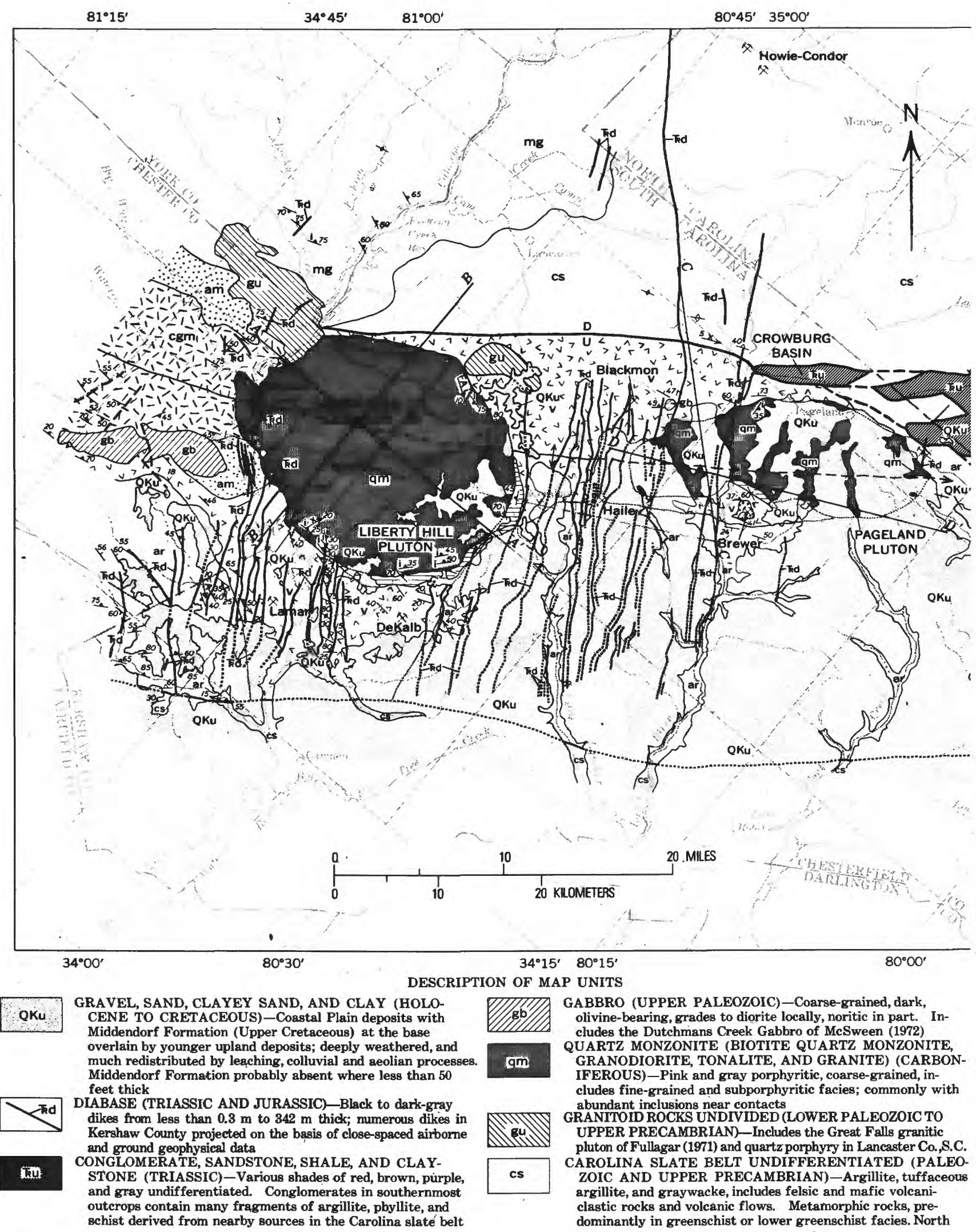

Figure 3.-Geologic map of the Haile-Brewer area, South Carolina. (Modified from Bell and Popenoe, 1976.) 


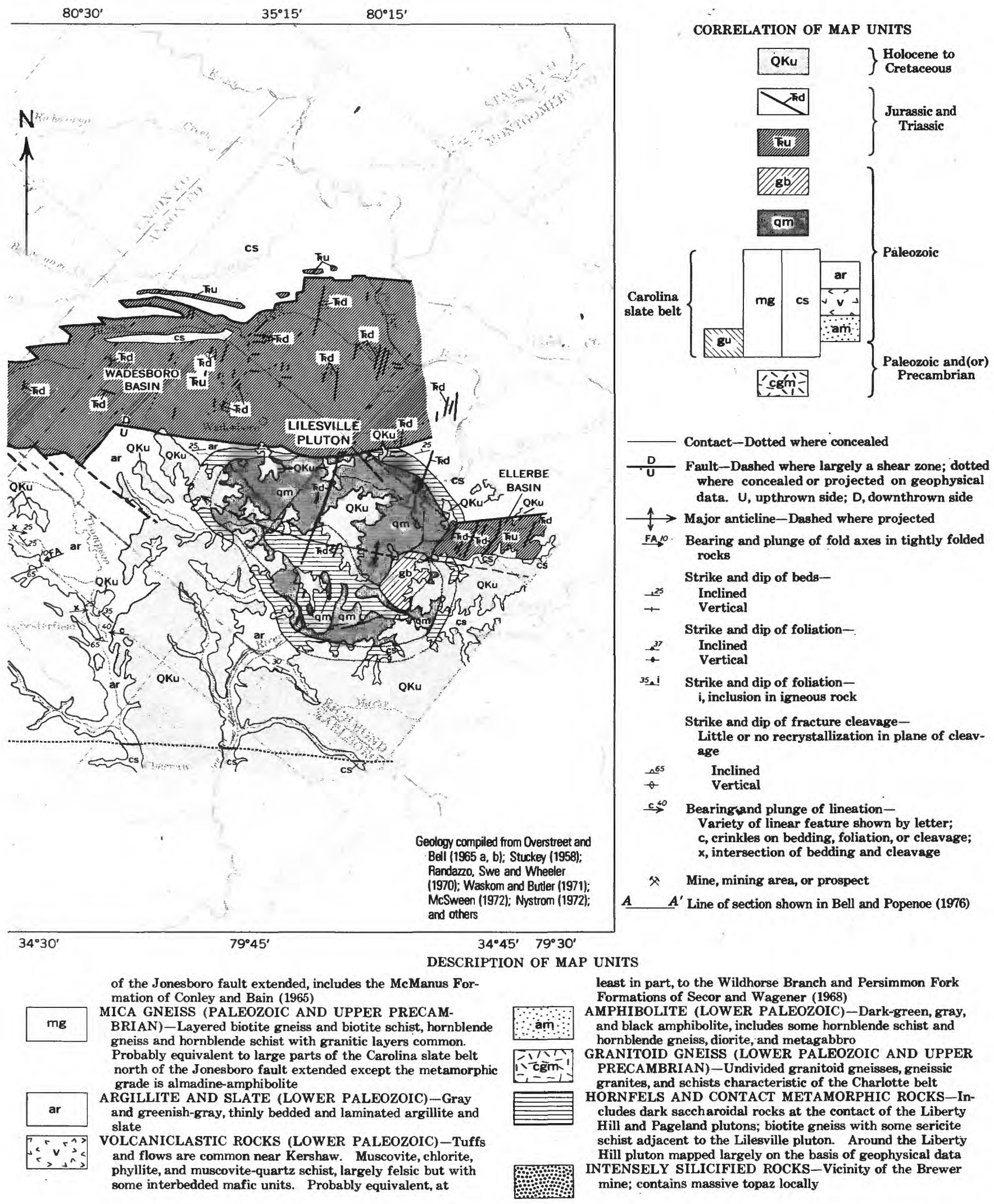

Figure 3.-Continued. 

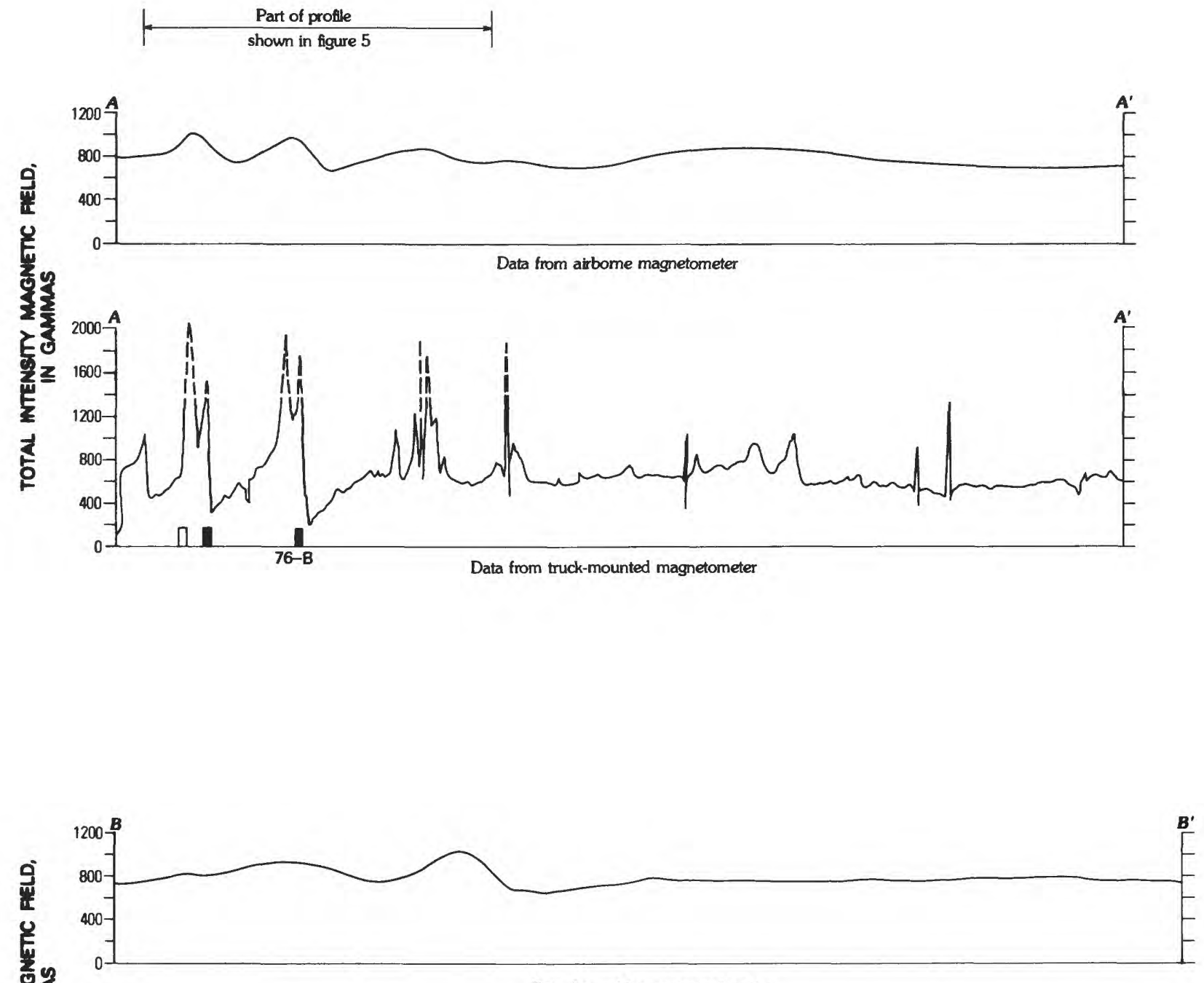

Data from airbome magnetometer
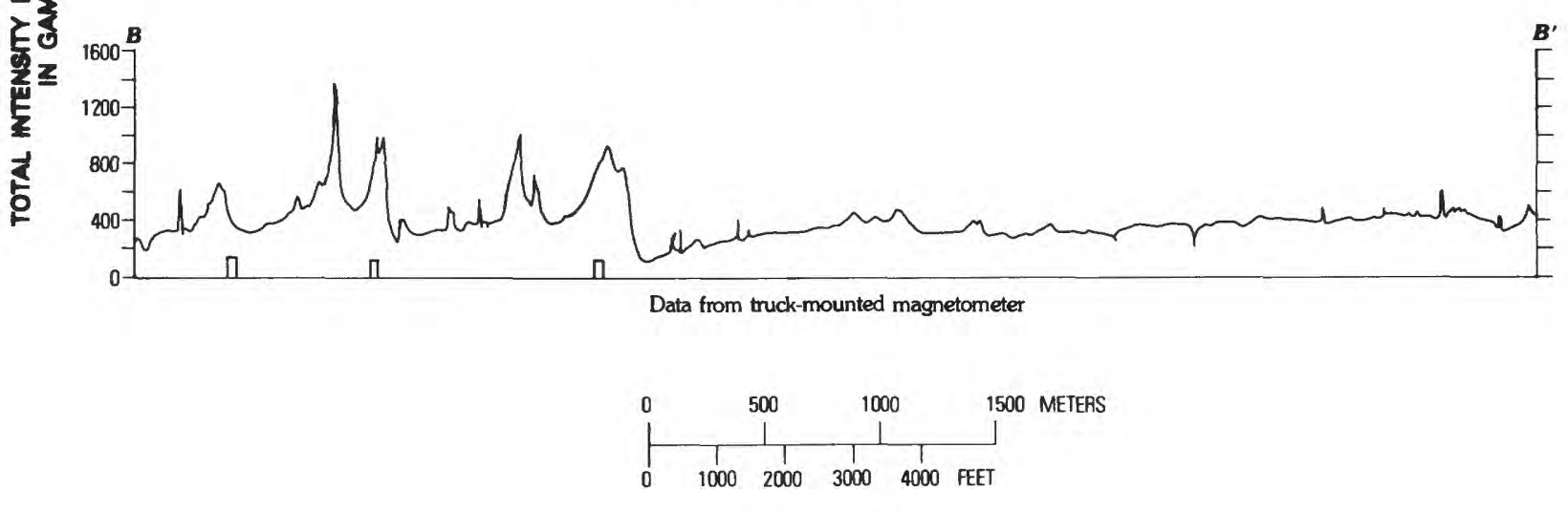

EXPLANATION

\section{ח}

Diabase dike-Solid symbol indicates outcrop, number indicates paleomagnetic sample site induded in table 5; open symbol indicates location projected from nearby outcrop or inferred from aeromagnetic data

FIGURE 4.-Comparison of profiles obtained by means of an airborne magnetometer carried at $122 \mathrm{~m}$ elevation with profiles obtained by means of a truck-mounted magnetometer. Locations of profiles are shown on figure 2. 

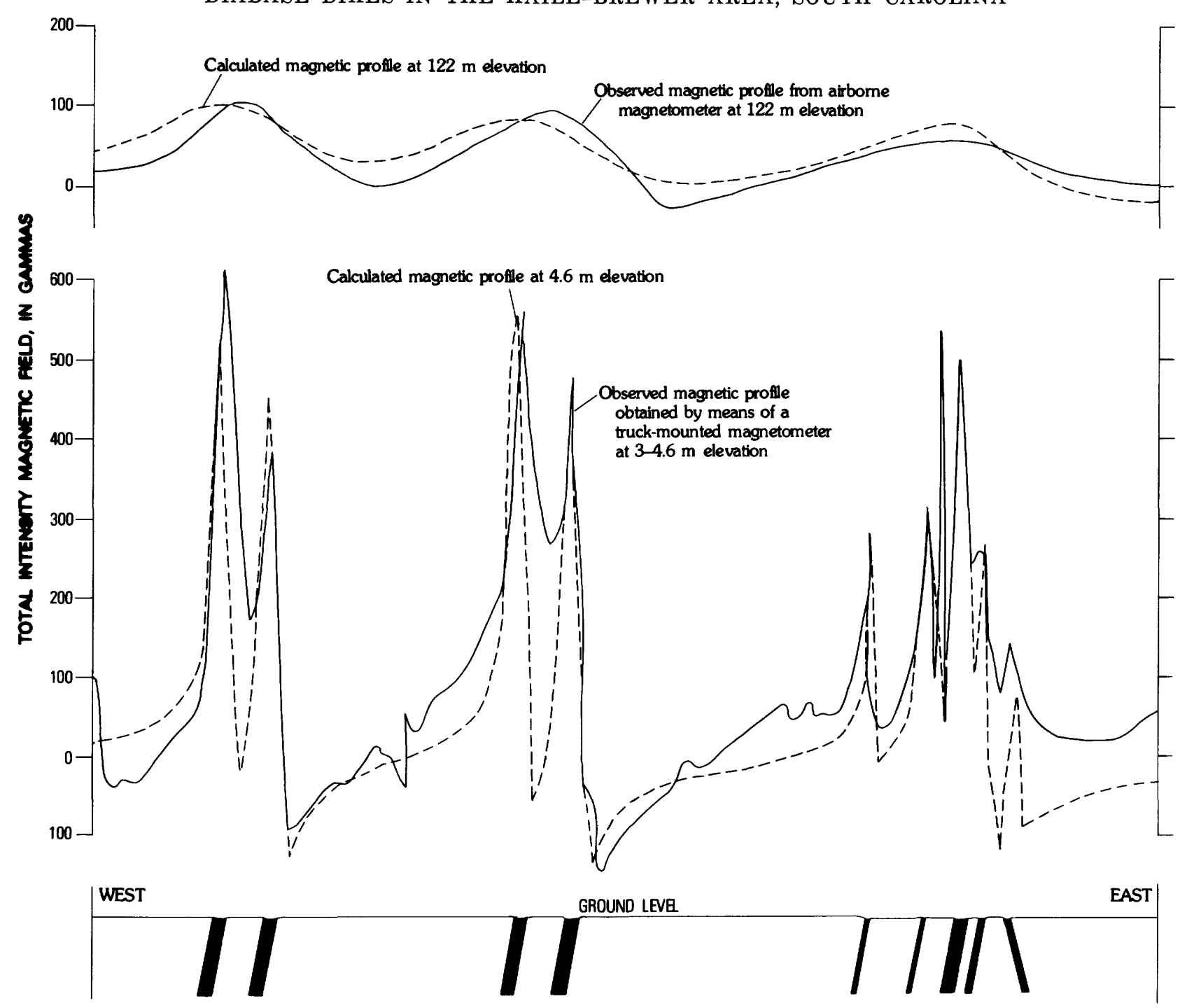

Simulated geologic profile (part of proflle A-A' shown in figure 4) striking N. $60^{\circ} \mathrm{E}$., showing dikes dipping $80^{\circ} \mathrm{E}$. or $80^{\circ} \mathrm{W}$. Dikes are 7.6, 15.2, or $30.4 \mathrm{~m}$ thick and are of infinite length and depth. Magnetic properties used are: magnetic vector with azimuth of $84^{\circ}$, indination $25^{\circ}$, and intensity $0.0027 \mathrm{emu}$ (electromagnetic unit). Conversion $2.7 \times 10^{-6} \mathrm{~A} / \mathrm{m}$ $\left(2.7 \times 10^{-3} \mathrm{emu} / \mathrm{cc}\right)$

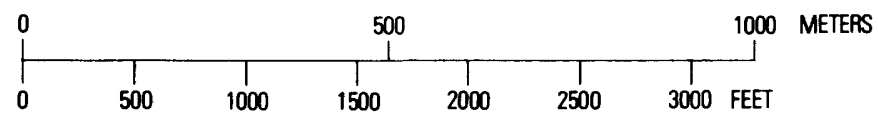

Figure 5.-Two-dimensional magnetic profiles of a simulated geologic profile calculated for $4.6 \mathrm{~m}$ and $122 \mathrm{~m}$ elevation.

addition, all comparably long anomalies are shown as a dike or dike swarm, even though no outcrop of diabase has been found. Other less pronounced or less continuous anomalies that may also be thin diabase dikes are not identified on figure 2 . All these anomalies indicate that the total number of diabase dikes in the area is very much larger than previously known.

\section{GEOLOGIC SETTING}

The geologic map of the Haile-Brewer area (fig. 3) shows that diabase dikes seen in outcrop or interpreted from the aeromagnetic map are not uniformly distributed. The dikes tend to be particularly abundant in parts of Kershaw and Lancaster Counties and along the Wateree River near the 
boundary between Kershaw and Fairfield Counties. There the dikes are cutting metamorphosed volcaniclastic rocks and argillites of the Carolina slate belt and to a lesser extent the coarse-grained Liberty Hill pluton, which intrudes rocks of the slate belt. The Pageland pluton, however, is cut by several diabase dikes, including a dike more than $300 \mathrm{~m}$ thick.

Included within the volcaniclastic unit in the Haile-Brewer area are sparse dark metamorphosed dikes, perhaps originally of andesitic or basaltic composition, which are not reflected in the aeromagnetic data. Neither were they detected by the truck-mounted magnetometer, perhaps, because they are thin, are discontinuous in outcrop, and are probably low in magnetite content.

Figure 3 shows diabase dikes extending as far as the limit of aeromagnetic data into areas where Coastal Plain sedimentary rocks are at the surface. Diabase dikes in the Haile-Brewer area are not known to cut either Cretaceous or younger sedimentary rocks. The strong magnetic anomalies extending from known diabase in areas of crystalline rocks into areas covered by rocks of the Coastal Plain reveal that the dikes extend beneath the overlying sedimentary rocks, where their orientation and extent can be interpreted from the magnetic data.

\section{DIABASE DIKES}

The dikes in the Haile-Brewer area are all olivinebearing tholeiitic diabase that is commonly intergranular or subophitic, is less commonly porphyritic, and contains feldspar or olivine phenocrysts. Megascopic variations in the dikes are mainly variations in grain size, texture, and abundance of olivine and feldspar phenocrysts. The average modal analysis of 16 thin sections of diabase from South Carolina reported by Chalcraft (1976) is given as follows:

\begin{tabular}{|c|c|}
\hline & $\begin{array}{c}\text { Volume } \\
\text { (percent) }\end{array}$ \\
\hline Plagioclase - & 53.3 \\
\hline Clinopyroxene & 30.9 \\
\hline Olivine & 11.2 \\
\hline Magnetite-ilmenite & 2.5 \\
\hline Biotite & Trace \\
\hline Alteration products & ${ }^{1} 3.3$ \\
\hline Total _. & 101.2 \\
\hline
\end{tabular}

${ }^{1}$ Average of 13 thin sections containing more than traces of alteration products.

In the field, the black to dark-gray diabase commonly has a weathering rind of characteristic orange-brown soft residuum. Many of the dikes weather spheroidally, and cores of the weathering spheroids, called core stones, are displaced as float and are commonly found scattered on the ground surface below the dike outcrop. In some thin dikes, a columnarlike jointing is perpendicular to the dike walls, and some dikes have distinct fine-grained chilled margins.

No systematic thickness measurements of diabase dikes have been made; thus, neither the average thickness nor the most common thickness is known. However, the thickness of a dike sampled in the present study was measured or estimated wherever the dike contacts could be at least approximately located. The thicknesses range from a few centimeters to more than $300 \mathrm{~m}$. The most common thicknesses appear to be about $3 \mathrm{~m}$ and about $15 \mathrm{~m}$. The largest dike, carefully measured by Steele (1971) where it is exposed in a deep road cut in Lancaster County, is 1,123 feet $(342.3 \mathrm{~m})$ thick. Dikes of this thickness appear to be very rare. Several artificial outcrops, perhaps as long as $100 \mathrm{~m}$, were found where as many as nine dikes ranging in width from less than $15 \mathrm{~cm}$ to as much as $22 \mathrm{~m}$ crop out. Where several thin dikes are close together, correlation of specific dikes from outcrop to outcrop is complicated by the similarity in appearance of the dikes, their nearly parallel strike, and their apparently anastomosing character.

Steele (1971), as a result of his studies of the thick dike in Lancaster County, concluded that the unusual thickness of that dike resulted from two injections of magma. The bifurcated character of the long aeromagnetic anomaly associated with the dike may indicate that, indeed, more than one dike did coalesce to produce an exceptionally thick dike. The dike probably coalesced before the magma in either dike cooled, because no textural indication of chilling between them is obvious.

In general, the diabase dikes in the Haile-Brewer area have the conspicuously oriented trend of about $\mathrm{N} .45^{\circ} \mathrm{W}$. that is characteristic of these dikes in the southeastern piedmont (fig. 1). However, the strike of individual dikes is locally varied. The dip of the dikes is commonly vertical, or nearly so.

In the Wadesboro Triassic and Jurassic (?) basin a short distance northeast of the Haile-Brewer area, diabase dikes trending northeast, as well as those trending northwest, appear to be common (Randazzo, Swe, and Wheeler, 1970; Randazzo and Copeland, 1976). Some of the northwest-trending diabase dikes are cut and offset by faults that parallel the southeastern border faults of the Wadesboro basin. At least two episodes of diabase-dike emplacement in the Wadesboro basin seem to be clearly indicated; therefore, several episodes of dike emplace- 
ment in the nearby Haile-Brewer area might also be expected, but they have not been recognized.

Although diabase dikes similar to dikes in the Triassic and Jurassic basins have been recognized and mapped in the Haile mine and elsewhere in the Haile-Brewer area, the airborne-magnetometer survey shows that the dikes are very much more numerous in the deeply weathered rocks than previously realized. Most commonly, the dikes crop out in stream beds, where dense unweathered diabase makes an obstruction that diverts the course of the stream. These obstructions and diversions produce local topographic expressions that reveal the trend of the dikes. Other outcrops along ridges or on interfluvial areas commonly are poorly exposed pavements or consist of clusters of boulders or cobblesize fragments. Bouldery ridges and trails of float cobbles are clear indications in areas of residual weathering that at least one diabase dike is present in the immediate vicinity, but the true nature and attitude of the dike or dikes are generally concealed. Detailed mapping of the dikes is impeded not only by deeply weathered country rocks in which the dikes are found but also by the common deeply weathered condition of the dikes themselves and by the heavily vegetated countryside. In these areas, the aeromagnetic map is particularly helpful as an aid to mapping.

In petrographic and chemical studies, Ragland, Rogers, and Justus (1968), Weigand and Ragland (1970), and Smith, Rose, and Lanning (1975) have divided the Triassic diabase into groups differing in chemistry, probable origin, and age. Weigand and Ragland (1970) separated eastern North American diabase dikes into three varieties. These are an olivine-normative diabase, a high- $\mathrm{TiO}_{2}$ group, and a low- $\mathrm{TiO}_{2}$ group. They further divided the high- $\mathrm{TiO}_{2}$ rocks by recognizing a subgroup of dikes having a high iron-oxide content. Smith and others (1975, p. 945) found that in Pennsylvania, copper and titanium contents were reliable indicators of diabase type. They divided the diabase intrusive rocks into three groups-Rossville, York Haven, and Quarryville types-having differing mineralogy and chemistry and corresponding approximately to the three varieties of Weigand and Ragland (Smith and others, 1975, p. 949-950). The Quarryville type corresponds to the olivine-normative variety, the York Haven type corresponds to the high- $\mathrm{TiO}_{2}$ quartznormative variety, and the Rossville type corresponds to the low- $\mathrm{TiO}_{2}$ quartz-normative type. Table 1 gives the chemical composition, trace-element content, and normative mineralogy of eight oriented samples of the $342.3 \mathrm{~m}$-thick dike in Lancaster County that were collected for magnetic studies. Most samples are quartz normative, but those collected near the margins are olivine normative. Table 2 summarizes the magnetic properties, measured during this study, of the eight samples for which chemical data are presented in table 1. Steele (1971) gave detailed analytical and petrographic data for 95 samples from this same dike.

The magnetic properties closely reflect the normative mineralogy. Both the induced magnetism and the remanent magnetism are distinctly lower near the western margin than in the central part of the dike. The sample from near the eastern margin of the dike is similar to the sample from the western margin in content of normative olivine, magnetite, and ilmenite; the magnetic properties are also similar, except that the remanent magnetism of the sample from the eastern margin is unaccountably high.

Using K-Ar age determinations of samples of Triassic diabase intrusive rocks collected in Connecticut and New Jersey, Armstrong and Besancon (1970) attempted to test the hypothesis that more than one period of intrusion occurred in the Newark Group rocks. They reviewed previous work of a similar nature that seemingly indicated that the ages of the volcanic rocks in the Newark Group (Upper Triassic and Lower Jurassic) are about 190 to 195 m.y. (million years). Armstrong and Besancon found that $\mathrm{K}$-Ar age determinations on diabase dikes gave results that were consistently and statistically older than the rocks the dikes cut. They $(1970$, p. 25) came to the conclusion that the diabase dikes in eastern North America are not suitable for "defining a point on the geologic time scale," either because of a loss of Ar from low-grade metamorphic rocks' at zeolite or prehnite-pumpellyite facies conditions or because of extraneous excess Ar.

\section{SAMPLING PROCEDURES}

The diabase dikes were sampled for study of paleomagnetic properties, beginning with the large dike in Lancaster County in 1969; a few dikes were sampled in 1975, and most of the remaining dikes described in this report were sampled in the spring of 1976. All the samples except those collected in 1969 were obtained by drilling outcrops using the methods described by Doell and Cox (1965) and using equipment similar to that they described.

The nature of the outcrops in the Haile-Brewer area and the general thinness of the dikes required 
TABLE 1.-Major-and minor-oxide composition, trace-element content, and normative minerology of a large diabase dike, Lancaster County, S.C.

[Rapid rock analysis by P. L. Elmore, Gillison Chloe, James Kelsey, Lowell Artis, Hezekiah Smith, and J. L. Glenn, all of the U.S. Geological is near the west margin, and sample 683 is near the east margin of the dike. L, present but below limit of detection; leadered where not calculated

\begin{tabular}{|c|c|c|c|c|c|c|c|c|}
\hline Sample - - & 677 & 676 & 678 & 679 & 680 & 681 & 682 & 683 \\
\hline \multicolumn{9}{|c|}{$\begin{array}{l}\text { Major- and minor-oxide compositions } \\
\text { [Rapid rock analyses, in weight percent] }\end{array}$} \\
\hline 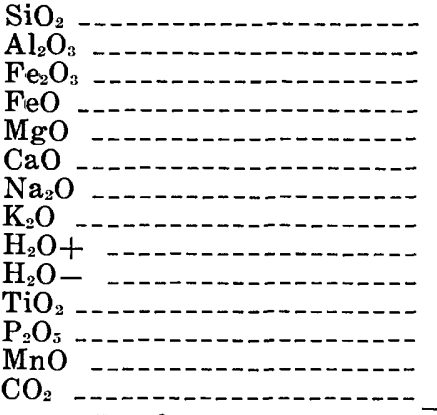 & $\begin{array}{r}50.0 \\
18.3 \\
1.2 \\
7.1 \\
6.5 \\
12.0 \\
2.4 \\
.62 \\
.89 \\
.21 \\
.56 \\
.05 \\
.15 \\
<.05 \\
\end{array}$ & $\begin{array}{r}50.5 \\
17.3 \\
2.5 \\
7.8 \\
5.5 \\
10.4 \\
2.5 \\
.91 \\
.82 \\
.28 \\
.76 \\
.10 \\
.17 \\
<.05 \\
\end{array}$ & $\begin{array}{r}51.1 \\
17.0 \\
2.4 \\
7.9 \\
5.5 \\
10.5 \\
2.5 \\
.99 \\
.74 \\
.26 \\
.76 \\
.10 \\
.17 \\
<.05 \\
\end{array}$ & $\begin{array}{c}51.0 \\
17.2 \\
2.0 \\
7.7 \\
5.8 \\
10.9 \\
2.4 \\
.87 \\
.97 \\
.23 \\
.67 \\
.09 \\
.18 \\
<.05 \\
\end{array}$ & $\begin{array}{c}51.4 \\
16.9 \\
2.3 \\
7.4 \\
6.0 \\
10.7 \\
2.4 \\
.90 \\
.63 \\
.25 \\
.72 \\
.09 \\
.19 \\
<.05 \\
\end{array}$ & $\begin{array}{r}51.0 \\
17.0 \\
2.5 \\
7.8 \\
5.8 \\
10.4 \\
2.2 \\
.87 \\
.76 \\
.44 \\
.76 \\
.10 \\
.19 \\
<.05 \\
\end{array}$ & $\begin{array}{c}51.2 \\
17.2 \\
2.9 \\
6.8 \\
6.1 \\
11.2 \\
2.4 \\
.85 \\
.12 \\
.25 \\
.65 \\
.09 \\
.18 \\
<.05 \\
\end{array}$ & $\begin{array}{c}50.4 \\
17.9 \\
1.2 \\
7.6 \\
6.2 \\
11.7 \\
2.2 \\
.66 \\
.95 \\
.25 \\
.60 \\
.07 \\
.15 \\
<.05 \\
\end{array}$ \\
\hline Total & 100 & 100 & 100 & 100 & 100 & 100 & 100 & 100 \\
\hline
\end{tabular}

Trace-element contents

[Spectrographic analyses, in parts per million]

\begin{tabular}{|c|c|c|c|c|c|c|c|c|c|}
\hline $\mathrm{Ag}$ & -1- & $\mathrm{L}$ & $\mathrm{L}$ & $\mathrm{L}$ & $\mathrm{L}$ & $\mathrm{L}$ & $\mathrm{L}$ & $\mathbf{L}$ & $\mathrm{L}$ \\
\hline $\mathrm{Ba}$ & -1-2-1 & 150 & 150 & 200 & 200 & 200 & 200 & 100 & 150 \\
\hline $\mathrm{Co}$ & 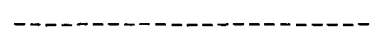 & 70 & 30 & 50 & 30 & 30 & 50 & 20 & 30 \\
\hline $\mathrm{Cr}$ & - - - - - - - - - - - - - & 500 & 200 & 300 & 200 & 200 & 200 & 150 & 300 \\
\hline $\mathrm{Cu}$ & 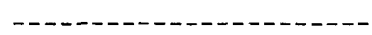 & 70 & 100 & 100 & 70 & 100 & 100 & 100 & 70 \\
\hline Mo & 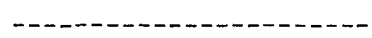 & 5 & 5 & 5 & 5 & 5 & 5 & 3 & 5 \\
\hline $\mathrm{Ni}$ & 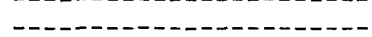 & 150 & 100 & 100 & 100 & 100 & 100 & 70 & 100 \\
\hline $\mathrm{Pb}$ & -10-2-1 & 3 & 10 & 7 & 3 & 3 & 3 & 3 & 3 \\
\hline $\mathrm{Se}$ & 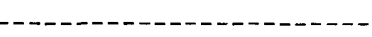 & 70 & 70 & 70 & 70 & 70 & 70 & 30 & 50 \\
\hline $\mathrm{Sr}$ & 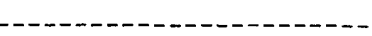 & 150 & 200 & 200 & 200 & 200 & 200 & 150 & 150 \\
\hline V & 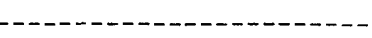 & 200 & 200 & 200 & 200 & 200 & 200 & 100 & 150 \\
\hline$Y$ & - - - - - - - - - - - - - - - - - - - - & 30 & 30 & 50 & 30 & 30 & 50 & 20 & 30 \\
\hline $\mathrm{Zr}$ & 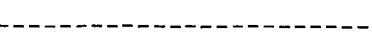 & 50 & 70 & 100 & 70 & 70 & 100 & 30 & 70 \\
\hline $\mathrm{Ga}$ & 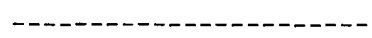 & 10 & 15 & 15 & 10 & 10 & 10 & 10 & 15 \\
\hline $\mathrm{Yb}$ & - - - - - - - - - - - - - - - & 3 & 3 & 5 & 3 & 3 & 5 & 2 & 3 \\
\hline
\end{tabular}

\begin{tabular}{|c|c|c|c|c|c|c|c|c|}
\hline \multicolumn{9}{|c|}{$\begin{array}{l}\text { CIPW mineral norms } \\
\text { [In weight percent] }\end{array}$} \\
\hline Quartz & & 1.01 & 1.30 & .99 & 1.79 & 2.81 & 1.57 & \\
\hline Orthoclase & 3.67 & 5.42 & 5.87 & 5.15 & 5.34 & 5.17 & 5.04 & 3.91 \\
\hline Albite & 20.34 & 21.30 & 21.22 & 20.34 & 20.37 & 18.72 & 20.36 & 18.68 \\
\hline Anorthite & 37.40 & 33.53 & 32.33 & 33.65 & 32.79 & 34.14 & 33.74 & 37.14 \\
\hline Diopside & 17.67 & 14.35 & 15.58 & 16.12 & 16.01 & 13.77 & 17.16 & 16.68 \\
\hline Wollastonite & $(9.02)$ & $(7.29)$ & $(7.91)$ & $(8.19)$ & $(8.17)$ & (7.01) & $(8.80)$ & (8.48) \\
\hline Enstatite & $(5.08)$ & $(3.87)$ & (4.16) & $(4.38)$ & $(4.55)$ & (3.79) & $(5.18)$ & $(4.57)$ \\
\hline Ferrosalite & $(3.57)$ & (3.19) & $(3.52)$ & $(3.55)$ & $(3.30)$ & (2.98) & (3.19) & (3.63) \\
\hline Hypersthene & 11.59 & 18.13 & 17.68 & 18.28 & 18.03 & 19.18 & 16.24 & 19.18 \\
\hline Enstatite & $(6.80)$ & $(9.93)$ & $(9.58)$ & $(10.09)$ & $(10.44)$ & $(10.74)$ & $(10.06)$ & $(10.70)$ \\
\hline Ferrosalite & (4.79) & $(8.20)$ & $(8.10)$ & $(8.19)$ & $(7.59)$ & $(8.44)$ & (6.19) & (8.49) \\
\hline Magnetite & 1.74 & 3.65 & 3.49 & 2.90 & 3.34 & 3.65 & 4.22 & 1.74 \\
\hline Ilmenite & 1.06 & 1.45 & 1.45 & 1.28 & 1.37 & 1.45 & 1.24 & 1.14 \\
\hline Apatite & .12 & .24 & .24 & .21 & .21 & .24 & .21 & .17 \\
\hline Olivine & 5.41 & & & $\ldots$ & $\ldots$ & $\ldots$ & ---- & .29 \\
\hline Forsterite & $(3.04)$ & $\ldots$ & --- & --.- & $-\ldots$ & $\ldots$ & 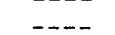 & $(.16)$ \\
\hline Fayalite & $(2.36)$ & --- & $-\ldots$ & ---1 r & $\ldots$ & -- & $\ldots$ & $(.14)$ \\
\hline Calcite & .12 & .11 &.$\overline{11}$ & .11 & .11 & .11 & .11 & .11 \\
\hline Total & 99.11 & 99.18 & 99.26 & 99.04 & 99.38 & 99.24 & 99.89 & 99.05 \\
\hline
\end{tabular}

that special care be taken to insure that the rock drilled was in its original place and not rotated or moved by erosion or other disturbances. Outcrops of diabase in the beds of streams, along the shores of Wateree Lake, and in deep road cuts where both contacts between dike and country rock are exposed gave the greatest confidence that the dikes were suitable for sampling. Other outcrops on bouldery ridges or flat pavement outcrops inspired less confidence that they were undisturbed. At these places, it was not always possible to determine that an outcrop was not a large spheroidal weathering boulder 
TABLE 2.-Magnetic properties and normative magnetite and ilmenite contents of a large diabase dike, Lancaster County, S.C. [wt. percent, percent by weight. $K, J i, J r$, and $J r+J i$ are in $10^{-4} \mathrm{emu}$ (electromagnetic units) $/ \mathrm{cm}^{3} . J i=0.554 K$. Koenigsberger ratio: $\left.Q=J r / J i\right]$

\begin{tabular}{|c|c|c|c|c|c|c|c|c|c|}
\hline \multirow[t]{2}{*}{ Sample } & \multirow{2}{*}{$\begin{array}{c}\text { Normative } \\
\text { magnetite } \\
\text { plus } \\
\text { i] menite } \\
\text { (wt. } \\
\text { percent) }\end{array}$} & \multicolumn{2}{|c|}{$\begin{array}{l}\text { Proportions, } \\
\text { normative } \\
\text { magnetite } \\
\text { plus ilmenite }\end{array}$} & \multirow{2}{*}{$\begin{array}{l}\text { Magnetic } \\
\text { suscepti- } \\
\text { bility, } K\end{array}$} & \multirow{2}{*}{$\begin{array}{l}\text { Induced } \\
\text { magnetiza- } \\
\quad \text { tion, } J i\end{array}$} & \multirow{2}{*}{$\begin{array}{l}\text { Remanent } \\
\text { magnetiza- } \\
\text { tion, } J r\end{array}$} & \multirow{2}{*}{$\begin{array}{c}\text { Koenigs- } \\
\text { berger } \\
\text { ratio, } Q\end{array}$} & \multirow{2}{*}{$\begin{array}{c}\text { Total } \\
\text { magnetiza- } \\
\text { tion, } \\
\boldsymbol{J} \boldsymbol{r}+\boldsymbol{J} i\end{array}$} & \multirow{2}{*}{$\begin{array}{l}\text { Inclina- } \\
\text { tion of } \\
\text { remanent } \\
\text { magneti- } \\
\text { zation } \\
\text { (degrees) }\end{array}$} \\
\hline & & $\begin{array}{l}\text { magnetite } \\
\text { (percent) }\end{array}$ & $\begin{array}{c}\text { ilmenite } \\
\text { (percent) }\end{array}$ & & & & & & \\
\hline $677 \ldots$ & 2.80 & 62 & 38 & 0.67 & 0.37 & 6.06 & 16.37 & 6.43 & 7 \\
\hline 676 & 5.10 & 72 & 28 & 17.90 & 9.91 & 9.96 & 1.01 & 19.87 & 20 \\
\hline $678----\cdots$ & 4.94 & 71 & 29 & 14.60 & 8.08 & 6.88 & .85 & 14.96 & 20 \\
\hline 679 & 4.18 & 69 & 31 & 10.70 & 5.92 & 3.36 & .57 & 9.28 & 44 \\
\hline 680 & 4.71 & 71 & 29 & 15.00 & 8.31 & 9.14 & 1.10 & 17.45 & 38 \\
\hline 681 --------- & 5.10 & 72 & 28 & 15.8 & 8.75 & 3.40 & .39 & 12.15 & -25 \\
\hline 682 & 5.46 & 77 & 23 & 13.4 & 7.42 & 3.04 & .41 & 10.46 & 20 \\
\hline $683----------$ & 2.88 & 60 & 40 & 10.2 & 5.65 & 19.0 & 3.36 & 24.65 & 18 \\
\hline
\end{tabular}

slumped from its original position or that the outcrop was not part of a large mass of colluvium that had slumped or slid as a unit. Probably some such disturbed outcrops were sampled and may be the cause of unrealistic results and a source of error.

An attempt was made at each site location to obtain at least three drill cores spaced about a meter apart. At some sites, the outcrop of diabase was too small to be conveniently drilled more than once or twice, or the diabase proved to be too deeply weathered to provide satisfactory samples. At other locations, only the fine-grained, chilled margin of the dike proved to be sufficiently unweathered to drill. Cores were obtained from a total of 39 sites. Of these, only 27 were used in statistical calculations and measurements of remanent magnetism, for the various reasons just mentioned. All sites drilled, however, are shown on figure 2.

In the laboratory, the drill cores were cut into as many 23-mm-long specimens as possible. Usually one to five specimens were cut from each core, and the total number of specimens involved is 163 . These were all measured and compared to obtain a single direction and intensity of remanent magnetism for each core. Table 3 shows the hierarchy of names used in the sampling and statistical calculations.

TABLE 3.-Definition of terms used in the sampling hierarchy

Dike or dike swarm. Diabase dike or several closely spaced dikes associated with a linear magnetic anomaly on which there is at least one drilling site. Labeled "Dike A," "Dike B," etc.

Site. Outcrop of diabase suitable for drilling by means of a portable diamond drill and from which a drill core was collected. Labeled " $76-1$, , "75-2," "676," etc.

Core or drill core. Drill core obtained at a site; $1-3$ cores obtained at each site; each core 20-40 cm long. Labeled "a," "b," "c," etc. Label follows site designation.

Specimen. One to five 23 -mm-long pieces cut from individual drill cores; magnetic properties were measured on these specimens. Labeled "A," "B," "C," etc. Label was added to site and core designations but is not included in tables.

\section{LABORATORY PROCEDURES}

Measurement of NRM.-In the laboratory, the specimens were given random sequential numbers, and their natural remanent magnetism (NRM) was measured. The instrument used and the procedures followed were the same as those described by Doell and Cox (1965). The data obtained from the spinner magnetometer were reduced, and the declination and inclination of the magnetic fields of the specimens were plotted by various computer programs (R. W. Bowen, R. R. Doell, and C. S. Grommé, unpublished computer program, 1966).

Alternating-field cleaning.-The plot of the data from the spinner magnetometer showed that there is much scatter in the NRM of the specimens. In order to decrease the dispersion in the data not related to the paleomagnetic field, all specimens were subjected to an alternating field of $100 \mathrm{Oe}$ (oersteds) to remove the extraneous magnetism. One hundred oersteds was chosen as the best level for cleaning all specimens, after specimens from several locations had been cleaned at incremental steps from $37 \mathrm{Oe}$ to as much as $500 \mathrm{Oe}$. The 100-Oe level of cleaning is close to the 150-Oe level found to be satisfactory by Beck (1972) and deBoer $(1967,1968)$ for samples of diabase from Pennsylvania and New England.

Calculation of paleomagnetic-pole positions.-In order to interpret the data obtained, most researchers of paleomagnetism rely on parametric statistics for dispersion on a sphere (Fisher, 1953). In order to calculate a paleomagnetic-pole position, the variations inherent in the specimens have been averaged for each hierarchy in the sampling program. The specimens from each site where at least three cores were obtained have been averaged to produce the mean declination and mean inclination of the NRM. These data together wtih the mean declinations and mean inclinations calculated after the specimens had been cleaned at 100,200, and $300 \mathrm{Oe}$ 
TABLE 4.-Results of spinner-magnetometer measurements on specimens of diabase dikes from the Haile-Brewer area, South [D, declination, in degrees; I, inclination, in degrees; $k$, estimate of Fisher's (1953) precision parameter;

\begin{tabular}{|c|c|c|c|c|c|c|c|}
\hline \multicolumn{3}{|c|}{ Site } & \multirow{2}{*}{$\begin{array}{c}\text { No. of } \\
\text { cores } \\
\text { averaged }\end{array}$} & \multicolumn{4}{|c|}{ Natural remanent magnetism } \\
\hline $\begin{array}{c}\text { Latitude N. } \\
\text { (degrees) }\end{array}$ & $\begin{array}{c}\text { Longitude W. } \\
\text { (degrees) }\end{array}$ & No. & & D & I & $k$ & $\alpha 95$ \\
\hline \multirow{3}{*}{$\begin{array}{l}34.33 \\
34.40\end{array}$} & 80.67 & $76-1$ & 3 & 18.9 & 10.6 & 27.9 & 23.8 \\
\hline & 80.72 & $76-2, a$ & ---- & 355.5 & -7.1 & --- & --- \\
\hline & & $76-2, \mathrm{~b}$ & ---- & 354.8 & -15.0 & ---- & --- \\
\hline 34.40 & 80.72 & $\begin{array}{l}76-3, \mathrm{a} \\
76-3, \mathrm{~b}\end{array}$ & --- & $\begin{array}{l}50.6 \\
41.3\end{array}$ & $\begin{array}{l}-20.6 \\
-20.0\end{array}$ & --- & --- \\
\hline \multirow[t]{2}{*}{34.40} & 80.72 & & --- & 341.7 & 15.2 & --- & --- \\
\hline & & $76-4, \mathrm{~b}$ & $--\bar{y}^{-}$ & 346.4 & 24.3 & $--\overline{3}$ & -716 \\
\hline \multirow{2}{*}{34.52} & $\begin{array}{l}80.69 \\
80.59\end{array}$ & $\begin{array}{l}76-8 \\
76-9, a\end{array}$ & $\begin{array}{c}5 \\
---\end{array}$ & $\begin{array}{c}341.7 \\
\left({ }^{1}\right)\end{array}$ & $\begin{array}{c}27.3 \\
\left({ }^{1}\right)\end{array}$ & $\begin{array}{r}4.3 \\
----\end{array}$ & $\begin{array}{l}41.6 \\
-\ldots-\end{array}$ \\
\hline & & $76-9, \mathrm{~b}$ & --- & 59.9 & 14.0 & --- & \\
\hline 34.51 & 80.59 & $76-10$ & 4 & 162.6 & -58.0 & 13.2 & 26.2 \\
\hline \multirow[t]{2}{*}{34.52} & 80.57 & $76-12, a$ & ---- & 10.3 & 32.9 & --- & $\ldots$ \\
\hline & & $76-12, \mathrm{a}$ & --- & $\begin{array}{l}8.2 \\
2.1\end{array}$ & 31.5 & --- & --- \\
\hline 34.55 & 80.60 & $76-13$ & 4 & $\begin{array}{l}2.1 \\
9.6\end{array}$ & $\begin{array}{l}40.0 \\
24.0\end{array}$ & $41 . \overline{9}$ & $\overline{14.4}$ \\
\hline 34.60 & 80.59 & $76-15$ & 4 & 13.2 & 68.8 & 12.7 & 26.8 \\
\hline 34.61 & 80.60 & $76-17$ & 4 & 15.1 & 38.5 & 10.7 & 29.5 \\
\hline \multirow[t]{2}{*}{34.58} & 80.56 & $76-19$, a & ---- & 149.0 & 42.5 & --- & -.-- \\
\hline & & $76-19, \mathrm{~b}$ & & 200.7 & 28.1 & & \\
\hline 34.55 & 80.53 & $76-20$ & 4 & 319.2 & 18.4 & 2.6 & 72.7 \\
\hline 34.40 & 80.81 & $76-21$ & 6 & 87.3 & 17.0 & 1.3 &.-- \\
\hline \multirow[t]{3}{*}{34.40} & 80.82 & $76-22, a$ & ---- & 174.9 & 12.8 & --- & --- \\
\hline & & $76-22, \mathrm{~b}$ & $\ldots$ & 184.8 & 72.7 & --- & -- \\
\hline & & $76-22, \mathrm{~b}$ & $\ldots$ & 162.6 & 70.7 & ---- & --- \\
\hline 34.40 & 80.82 & $76-23$ & ---- & 178.5 & 21.3 & $\ldots$ & - \\
\hline 34.40 & 80.81 & $76-24$ & 4 & 161.3 & 39.5 & 2.5 & 74.4 \\
\hline 34.40 & 80.83 & $76-25$ & 3 & 115.0 & -15.2 & 1.1 & 0.0 \\
\hline 34.40 & 80.83 & 76-26, a & --- & 235.6 & 9.8 & --- & --- \\
\hline & 80.83 & $\begin{array}{l}76-26, b \\
76-27\end{array}$ & $-\overline{3}$ & $\begin{array}{r}(1) \\
197.5\end{array}$ & $\overline{16 . \overline{5}}$ & 17.7 & $30 . \overline{2}$ \\
\hline \multirow{2}{*}{$\begin{array}{l}34.40 \\
34.40\end{array}$} & 80.83 & $76-28$, a & $\ldots$ & 96.0 & 29.5 & $\ldots$ & $\ldots$ \\
\hline & & $76-28, \mathrm{~b}$ & & 100.3 & 26.6 & & \\
\hline \multirow{3}{*}{$\begin{array}{l}34.42 \\
34.41\end{array}$} & 80.85 & $76-29$ & 5 & 102.9 & -62.8 & 1.8 & 85.6 \\
\hline & 80.85 & $76-30, a$ & --. & 303.0 & 22.0 & -.-- & $\ldots$ \\
\hline & & $76-30, \mathrm{~b}$ & $\ldots$ & 145.3 & 32.7 & & \\
\hline 34.45 & 80.86 & $76-31$ & 5 & 52.6 & 2.8 & 106.6 & 7.4 \\
\hline 34.65 & 80.50 & 676 & 9 & 7.6 & 19.9 & 40.4 & 8.2 \\
\hline 34.57 & 80.60 & $75-1$ & --.- & 311.6 & 45.1 & --- & $-\ldots$ \\
\hline \multirow[t]{2}{*}{34.60} & 80.60 & $75-2, \mathrm{a}$ & -.-- & 77.2 & 39.9 & ---- & ---- \\
\hline & & $75-2, \mathrm{~b}$ & --- & 3.0 & 30.6 & ---- & --- \\
\hline
\end{tabular}

${ }^{1}$ Not measured.

are shown in table 4. Data from specimens, cleaned at $100 \mathrm{Oe}$, from sites on the same linear magnetic anomaly (fig. 2), and therefore presumably on the same diabase dike, have then been averaged to produce a mean virtual geomagnetic-pole (VGP) position for individual dikes. Data from sites on closely spaced thin dikes in a dike swarm have been combined and used to calculate a VGP for the dikes in that swarm. The paleomagnetic direction, paleopole position, and statistical parameters for each dike, calculated from data derived from specimens cleaned at $100 \mathrm{Oe}$, are shown in table 5. No correction for structural rotation or folding of the rocks in which the dikes are emplaced has been applied to the data.

\section{RESULTS}

The VGP calculated for each dike or dike swarm (table 5) results from combining data having vari- ous reliabilities. For instance, the calculated pole for dike $\mathrm{A}$ is a combination of data from three sites on an aeromagnetic anomaly (fig. 2) that extends about $16 \mathrm{~km}$ in the volcaniclastic unit near the contact with the Liberty Hill pluton. The data from these three sites give conflicting results. One site, 76-10 (table 4 ), is an outcrop in the bed of a stream; it has ample area for core drilling and yields significant statistical results. The second site, 76-9 (table 4), is a roadcut, $0.32 \mathrm{~km}$ to the northwest, where only two cores were obtained; perhaps as a result of undetected disturbance by road builders, these two cores yield divergent results that are not significant for pole calculations. The third site, $76-13$, is $2.74 \mathrm{~km}$ northwest of the second site. Although also an artificial exposure, it yields results that are within acceptable statistical limits but have a magnetic direction that is nearly $180^{\circ}$ from that of site $76-10$ on this 
Carolina, untreated and after cleaning by subjection to alternating magnetic fields of intensities of 100, 200, and 300 oersteds $\alpha 95$, radius of cone of confidence at 95 percent probability level, in degrees; Oe, oersted]

\begin{tabular}{|c|c|c|c|c|c|c|c|c|c|c|c|}
\hline \multicolumn{12}{|c|}{ Magnetism remaining after cleaning at the indicated intensities } \\
\hline \multicolumn{4}{|c|}{$100 \mathrm{Oe}$} & \multicolumn{4}{|c|}{$200 \mathrm{Oe}$} & \multicolumn{4}{|c|}{$300 \mathrm{Oe}$} \\
\hline D & $\mathrm{I}$ & $k$ & $\alpha 95$ & D & $\mathbf{I}$ & $k$ & $\alpha 95$ & D & $\mathbf{I}$ & $k$ & $\alpha 95$ \\
\hline 6.8 & 4.6 & 81.4 & 13.8 & 359.1 & -0.9 & 101.3 & 12.3 & 353.4 & -21.8 & 5.9 & 56.1 \\
\hline 12.8 & -12.4 & --- & ---- & --- & $-\cdots$ & --- & --- & $-\cdots$ & ---- & ---- & --- \\
\hline $\begin{array}{l}15.6 \\
41.7\end{array}$ & -19.8 & --- & ---- & --- & $\cdots$ & --- & ---- & $-\cdots$ & $-\cdots$ & --- & -..- \\
\hline $\begin{array}{l}41.7 \\
43.0\end{array}$ & $\begin{array}{l}-26.4 \\
-24.9\end{array}$ & --- & 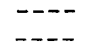 & --- & - & $\begin{array}{l}---- \\
-----\end{array}$ & 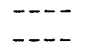 & $\ldots$ & -... & $-\cdots$ & -- \\
\hline 349.4 & 13.2 & --- & $\ldots$ & --- & --- & ---- & ---- & $-\cdots$ & $-\cdots$ & ---- & $-\cdots$ \\
\hline 0.1 & 3.0 & --- & --- & $-\ldots$ & - & --- & --- & -1 & $\cdots$ & ---- & --- \\
\hline 238.3 & 53.7 & 2.2 & 68.4 & 219.6 & 39.8 & 1.6 & $\ldots-$ & 157.0 & 57.6 & 1.4 & 0.0 \\
\hline 5.5 & $\begin{array}{l}16.3 \\
12.7\end{array}$ & --- & --- & $-\cdots$ & --- & --- & --- & --- & --- & --- & $-\cdots$ \\
\hline $\begin{array}{r}11.8 \\
175.8\end{array}$ & $\begin{array}{r}12.7 \\
-24.4\end{array}$ & $3 . \overline{6}$ & $\overline{56 . \overline{6}}$ & $\overline{174 . \overline{3}}$ & $4 . \overline{6}$ & $\overline{5.2}$ & $61 . \overline{1}$ & $\overline{184 . \overline{4}}$ & $20 . \overline{0}$ & $\overline{5.8}$ & $\overline{56.6}$ \\
\hline $\begin{array}{r}175.8 \\
16.6\end{array}$ & $\begin{array}{r}-24.4 \\
33.1\end{array}$ & --- & ---- & $-\cdots$ & --- & $\ldots$ & - - - & -- & $\ldots$ & - - - & 0.0 \\
\hline 10.1 & 27.2 & ---- & --- & $-\cdots$ & ---- & --- & ---- & ---- & ---- & --- & -- \\
\hline 4.5 & 32.4 & & & & $17 \bar{a}$ & & & & & & \\
\hline 3.5 & 20.2 & 126.8 & 8.2 & 357.6 & 17.9 & 36.8 & 20.6 & 340.8 & 13.4 & 11.7 & 37.8 \\
\hline 11.7 & 60.1 & 158.8 & 7.3 & 15.6 & 58.2 & 104.3 & 7.5 & 22.3 & 46.3 & 15.4 & 17.6 \\
\hline 9.1 & 32.4 & 39.4 & 14.8 & 2.4 & 36.2 & 17.1 & 22.9 & 336.2 & 50.8 & 5.3 & 44.2 \\
\hline 169.7 & $\begin{array}{l}44.4 \\
280\end{array}$ & --- & --- & --- & ---- & --- & ---- & --- & $-\cdots$ & ---- & ---- \\
\hline $\begin{array}{l}197.2 \\
234.3\end{array}$ & $\begin{array}{l}28.0 \\
66.0\end{array}$ & 3.2 & 60.9 & 264.5 & 64.8 & 3.6 & 77.1 & 302.8 & 59.5 & 2.4 & $0 . \overline{0}$ \\
\hline 33.0 & 63.9 & 2.5 & 54.4 & 10.4 & 68.2 & 1.9 & $\ldots$ & 343.7 & 68.0 & 2.2 & --- \\
\hline 187.3 & 13.4 & --- & --- & --- & - - & --- & - & - - - & $\ldots$ & ---- & $\ldots$ \\
\hline 179.3 & 61.0 & --- & --- & --- & --- & ---- & --- & --- & $-\cdots$ & ---- & --- \\
\hline 179.6 & 62.1 & --- & ---- & --- & --- & --- & $-\cdots$ & --- & --- & --- & ---- \\
\hline $\begin{array}{l}184.2 \\
196.4\end{array}$ & $\begin{array}{l}14.0 \\
52.0\end{array}$ & $\overline{2 . \overline{2}}$ & $\overline{82.3}$ & $19 \overline{9} . \overline{8}$ & $5 \overline{2.2}$ & $1 . \overline{4}$ & $0 . \overline{0}$ & $\overline{209 . \overline{6}}$ & $\overline{55 . \overline{6}}$ & $\overline{1.5}$ & 0.0 \\
\hline 153.0 & 47.6 & 1.4 & 0.0 & 157.4 & 48.8 & 1.4 & 0.0 & 198.9 & 65.5 & 1.5 & 0.0 \\
\hline 205.9 & 11.0 & --- & --- & --- & --- & --- & --- & --- & ---- & --- & ---- \\
\hline 183.3 & 11.3 & & $=-$ & --- & --- & 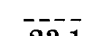 & & & & & \\
\hline 190.4 & 6.7 & 56.3 & 16.6 & 182.0 & 0.4 & 23.1 & 26.3 & 194.5 & 2.8 & 56.6 & 16.5 \\
\hline 111.7 & 21.8 & --- & $\begin{array}{l}---- \\
----\end{array}$ & 162.2 & 9.2 & $\cdots--$ & ---- & $-\cdots$ & --- & -.-- & --- \\
\hline 140.7 & 21.0 & $2 . \overline{0}$ & $\overline{75.3}$ & 167.8 & $\begin{array}{r}0.2 \\
-11.9\end{array}$ & $\overline{1.0}$ & $-\cdots$ & $-\ldots$ & --- & --- & $\cdots$ \\
\hline 179.7 & -3.5 & ---- & ---- & & & & 0.0 & $\cdots$ & $\cdots$ & --- & -- \\
\hline 358.3 & $\begin{array}{l}42.4 \\
32.3\end{array}$ & & $\ldots-$ & 175.2 & 25.2 & --- & -.- & --- & --- & --- & --- \\
\hline 182.8 & $\begin{array}{r}32.3 \\
9.7\end{array}$ & & 4.3 & 16.8 & 5.2 & & & --- & --- & -.-- & $\ldots$ \\
\hline 15.0 & $\begin{array}{r}9.7 \\
17.9\end{array}$ & 30.1 & 9.5 & 10.0 & 0.4 & 15.7 & 24.0 & $\cdots$ & --- & --- & $\ldots$ \\
\hline $\begin{array}{r}5.6 \\
22.1\end{array}$ & $\begin{array}{l}17.9 \\
36.7\end{array}$ & --- & $\begin{array}{r}0.0 \\
-\ldots-\end{array}$ & 17.8 & $\overline{36.6}$ & --- & --- & $\cdots$ & --- & --.- & --- \\
\hline $\begin{array}{l}22.1 \\
94.0\end{array}$ & $\begin{array}{l}36.7 \\
35.3\end{array}$ & $\ldots$ & -... & 101.0 & 34.5 & - & $\begin{array}{l}---- \\
----\end{array}$ & $\overline{114 . \overline{5}}$ & $\overline{29.3}$ & $\begin{array}{l}-- \\
---\end{array}$ & --- \\
\hline 10.0 & 35.4 & -- & --- & 11.4 & 35.1 & -- & --- & 1.1 & 37.4 & --- & --- \\
\hline
\end{tabular}

aeromagnetic anomaly. The reason the data are so divergent is not known, but it may be that unrecognized multiple dikes are present or that the aeromagnetic anomaly or some other factor has been misinterpreted. The consequences of combining data from these sites are reflected in a large radius of the cone of confidence for the paleomagnetic direction and a small precision parameter, $k$, for the VGP from this dike.

Dike B (fig. 2) is a 28.2-km-long segment of an aeromagnetic anomaly on which three sites were drilled. Suitable cores were obtained from only two of the sites, which were $2.09 \mathrm{~km}$ apart. The VGP obtained by combining data from all specimens from these two sites yielded a pole position having a small cone of confidence at the 95-percent level, a large precision parameter, $k$, and normal polarity. It seems likely therefore, at least for the distance between the two sites, that this aeromagnetic anomaly results from a diabase dike for which the VGP is reliable.

Data from two sites on Dike $C$ produced a reliable VGP with reverse polarity. The diabase drilled at the two sites, however, differs in lithology in both hand specimens and thin section. At one site, the rock is porphyritic and contains abundant feldspar phenocrysts, which in thin section are much clouded with opaque alteration products and calcite. The other site, in contrast, is a more typical nonporphyritic diabase. Apparently the appearance of the diabase changes along strike.

On Dike D, four sites were drilled, but only two sites provided the required cores and specimens that when combined met accepted reliability criteria. Dike 676 is the dike in Lancaster County that is more than $305 \mathrm{~m}$ thick. The data for this dike give a reliable VGP. 
TABLE 5.-Paleomagnetic directions and paleomagnetic pole positions for diabase dikes and dike swarms in the Haile-Brewer area, South Carolina

[ $\alpha 95$, radius of cone of confidence at 95 percent probability level; $k$, estimate of Fisher's (1953) precision parameter; Lat. and Long., latitude and longitude of the virtual geomagnetic pole (VGP); P, polarity; N, north-seeking (reverse) polarity; S, south-seeking (normal) polarity: Sm and $\delta \mathrm{p}$, semiaxes of the confidence oval about the VGP]

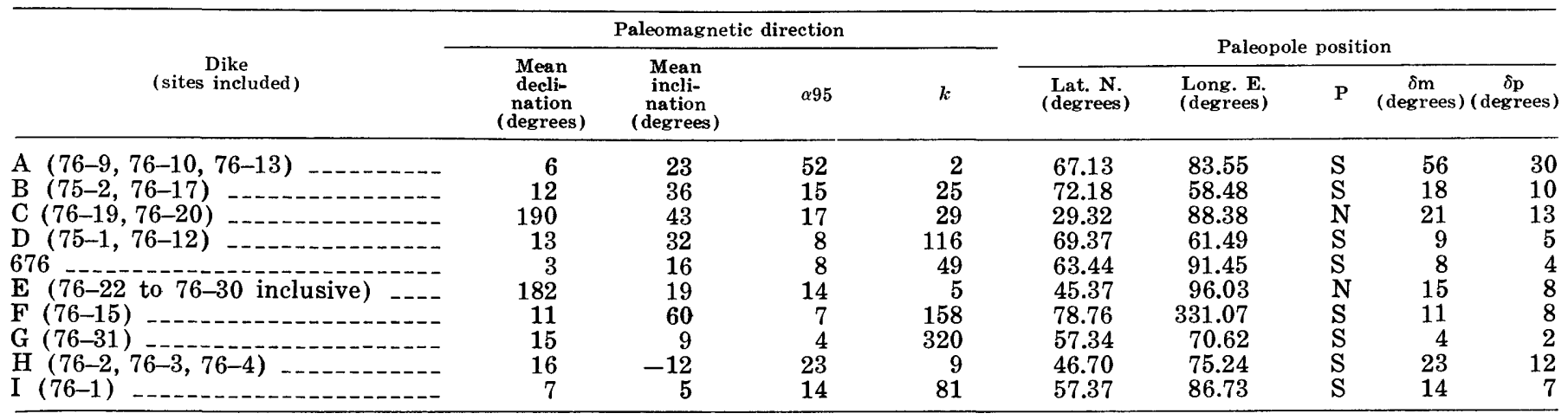

EXPLANATION

A. Dike, weathered, probably about $14 \mathrm{~m}$ thick; core stones sampled; fine to very fine grained; abundant olivine, some much altered; opaque min-

erals conspicuous; intergranular texture.
B. Dike, probably about $15 \mathrm{~m}$ thick; fine to medium fine grained; olivine bearing, partly altered; opaque minerals sparse.
C. Dike, outcrop in road gutter and stream bed; no contacts seen; in part porphyritic; in thin section, possible relict olivine; pyroxene altered; all plagioclase much clouded with opaque alteration material; some clots of calcite with very fine quartz; sparse chlorite; opaque minerals abundant.

D. Dike, outcrops as bouldery ridge and on fiood plain: about $23 \mathrm{~m}$ thick; fine grained; olivine sparse, altered; intergranular texture.

676. Dike, sampled in deep road cut; about $342 \mathrm{~m}$ thick; described by Steele (1971); contains as much as 5 percent olivine and 4 percent

opaque minerals: intergranular texture. well exposed at location site; some have abundant transverse joints; dike trends range from $\mathrm{N}$. $3^{\circ} \mathrm{W}$. to $\mathrm{N}, 27^{\circ} \mathrm{W}$.

F. Dike, weathered outcrops are crumbly; fine to medium grained; abundant large unaltered olivine; abundant opaque minerals both fine and very fine; intergranular texture.

G. Dike, weathered; core stones sampled; strikes N. $30^{\circ}$ W., dips vertically; abundant transverse joints; about $3 \mathrm{~m}$ thick.

H. Group of 3 closely spaced thin dikes, $1 \mathrm{~m}, 3 \mathrm{~m}$, and $3.4 \mathrm{~m}$ thick, respectively; crops out in road gutter; some dikes show unweathered very fine

grained chilled margins and have coarser grained weathered interiors.
I. Dike, outcrop in road cut, weathered; core stones sampled.

In table 5, $\mathrm{E}$ represents a dike swarm of as many as nine closely spaced dikes ranging in thickness from $0.6 \mathrm{~m}$ to $2.7 \mathrm{~m}$; the swarm also includes one dike about $21 \mathrm{~m}$ thick. Because these dikes are so closely spaced and because they have similar trends and similar appearances, they have been considered as if they were the result of a single intrusion of magma along closely spaced fractures. The paleomagnetic direction that results from combining data from these sites meets the standards for reliability; the data provide a cone of confidence within the 95-percent probability level at $14^{\circ}$. The dike swarm, however, has a reverse, north-seeking, polarity.

Data are used from only one site on each of the dikes F, G, and I, but the results of paleomagneticdirection and paleopole-position calculations give small cones of confidence and large precision parameters, $k$.

In table 5, $\mathrm{H}$ represents a dike swarm of as many as six dikes, ranging from about $0.2 \mathrm{~m}$ to about $3.6 \mathrm{~m}$ in thickness, emplaced in the coarse-grained Liberty Hill pluton. Only three of the dikes, however, were suitable for core drilling. Possibly one of these thin dikes may be represented by a small anomaly in each of the aeromagnetic profiles (fig. 4, southwesternmost open-dike symbol in each profile) ob- tained by means of a truck-mounted magnetometer. The VGP's calculated for the dikes designated A through I and 676 seem to fall into three groups on the basis of their positions and polarities (table 5). The average positions of the paleopoles of each of these three groups are presented in table 6, which consists of two parts, $A$ and $B$. The pole positions given in part $A$ are calculated by using all the data listed in table 5, including some from sites where fewer than three cores were obtained and which therefore yield data that do not meet the statistical standards of data used from other sites. Part $B$ shows pole positions calculated by using only data that meet the strictest statistical standards applied to these data.

The number of specimens from which data are used in the calculations for part $B$ of table 6 is less than half the number from which data are used in part $A$, but part $B$ shows the probably more reliable pole positions. The paleomagnetic pole positions shown in table 6 , part $B$, for groups 1 and 2 are very close, but the poles show opposing polarity. Group 3 consists of specimens from only one site, and although the statistical parameters indicate that confidence should be placed in the results of the calculations, the positions calculated are so far from expected Mesozoic or Paleozoic paleopole positions 
TABLE 6.-Summary of magnetic data and paleomagnetic pole positions for diabase dikes and dike swarms in the HaileBrewer area, South Carolina

[Group 1, specimens from dikes A, B, D, 676, G, and I; group 2, specimens from dike C (part A) and dike swarms E (parts A \& B) and H (part A) ; group 3, specimens from dike $F$. $x$, number of sites from which data are combined; $y$, number of specimens used; Decl., mean declination; and 'Long. E. nation: $\alpha 95$, radius of cone of confdence at 95 percent probability level; k, estimate of Fisher's (1953) precision parameter; Lat. $N$. seeking (normal) polarity; $\delta \mathrm{m}$ and $\delta \mathrm{p}$, semiaxes of the confidence oval about the VGPJ

\begin{tabular}{|c|c|c|c|c|c|c|c|c|c|c|}
\hline \multirow[b]{2}{*}{ Specinens } & \multirow[b]{2}{*}{$x / y$} & \multicolumn{4}{|c|}{ Paleomagnetic direction } & \multicolumn{5}{|c|}{ Paleopole position } \\
\hline & & $\begin{array}{c}\text { Decl. } \\
\text { (degrees) }\end{array}$ & $\begin{array}{c}\text { Incl. } \\
\text { (degrees) }\end{array}$ & $\begin{array}{c}\alpha 95 \\
\text { (degrees) }\end{array}$ & $k$ & $\begin{array}{c}\text { Lat. N. } \\
\text { (degrees) }\end{array}$ & $\begin{array}{l}\text { Long. E. } \\
\text { (degrees) }\end{array}$ & $\mathbf{P}$ & $\begin{array}{c}\delta \mathrm{m} \\
\text { (degrees) }\end{array}$ & $\begin{array}{c}\delta \mathrm{p} \\
\text { (degrees) }\end{array}$ \\
\hline \multicolumn{11}{|l|}{ Part $\mathrm{A}$-all sites: } \\
\hline $\begin{array}{l}\text { Group } 1 \text { - } 1 \text {---- } \\
\text { Group } 2 \\
\text { Group } 3 \\
3\end{array}$ & $\begin{array}{r}10 / 37 \\
14 / 37 \\
1 / 4\end{array}$ & $\begin{array}{c}9.8 \\
177.1 \\
11\end{array}$ & $\begin{array}{l}17.3 \\
43.4 \\
60\end{array}$ & $\begin{array}{c}13.6 \\
28.0 \\
7\end{array}$ & $\begin{array}{r}4 \\
2 \\
158\end{array}$ & $\begin{array}{l}63 \\
30 \\
79\end{array}$ & $\begin{array}{r}78 \\
102 \\
331\end{array}$ & $\begin{array}{l}\mathrm{S} \\
\mathrm{N} \\
\mathrm{S}\end{array}$ & $\begin{array}{l}14 \\
35 \\
11\end{array}$ & $\begin{array}{r}7 \\
22 \\
8\end{array}$ \\
\hline \multicolumn{11}{|l|}{$\begin{array}{l}\text { Part B-only sites } \\
\text { yielding signficant } \\
\text { VGP's: }\end{array}$} \\
\hline $\begin{array}{l}\text { Group } 11-\ldots- \\
\text { Group } 2 \\
\text { Group } 3 \\
3\end{array}$ & $\begin{array}{r}5 / 25 \\
1 / 3 \\
1 / 4\end{array}$ & $\begin{array}{r}7.7 \\
190.4 \\
11\end{array}$ & $\begin{array}{r}14.7 \\
6.7 \\
60\end{array}$ & $\begin{array}{r}6.3 \\
16.6 \\
7\end{array}$ & $\begin{array}{l}22 \\
56.3 \\
158\end{array}$ & $\begin{array}{l}62 \\
51 \\
79\end{array}$ & $\begin{array}{r}83 \\
82 \\
331\end{array}$ & $\begin{array}{l}\mathrm{S} \\
\mathrm{N} \\
\mathrm{S}\end{array}$ & $\begin{array}{r}6.5 \\
16.6 \\
11\end{array}$ & $\begin{array}{l}3.3 \\
8.4 \\
8\end{array}$ \\
\hline
\end{tabular}

that they are not paleomagnetically or geologically realistic and should probably be disregarded.

\section{CONCLUSIONS}

The diabase dikes in the Haile-Brewer area associated with aeromagnetic anomalies yield paleomagnetic poles that are statistically acceptable at either $62^{\circ} \mathrm{N}$., $83^{\circ}$ E., normally polarized, or $51^{\circ}$ N., $82^{\circ}$ E., reversely polarized. These poles seem to be close to the mean Late Triassic paleomagnetic pole given as $68^{\circ}$ N., $97^{\circ}$ E. by McElhinny (1973, p. 202, table 16) and as $66^{\circ}$ N., $95.5^{\circ}$ E. by Beck (1972, p. 5684) for eastern North America Upper Triassic igneous rocks. The mean pole of $68.6^{\circ} \mathrm{N}$., $100.9^{\circ}$ E., calculated by Smith $(1976$, p. 604 , table 3$)$ for his data from diabase intrusions in Connecticut, Maryland, and southern Pennsylvania is less: than $20^{\circ}$ from the pole positions calculated for the South Carolina dikes. The South Carolina paleomagnetic poles differ by a maximum of $22.5^{\circ}$ from the $62^{\circ} \mathrm{N}$., $104.5^{\circ}$ E. pole that Beck $(1972$, p. 5680 , and table 2$)$ considered to be the best estimate of the Late Triassic geomagnetic pole derived from his samples of southeast Pennsylvania diabase intrusions. The South Carolina dikes, therefore, are likely to have been emplaced during the same time interval as these other diabase intrusions in the Late Triassic. No other group of distinctively different poles was found that might be related to the various chemical and petrographic groups recognized by Smith and others (1975) and Weigand and Ragland (1970). However, not enough dikes, sites, or cores were included in the study for us to be entirely satisfied that a group of dikes yielding some other paleomagnetic pole does not exist in the Haile-Brewer area.

\section{REFERENCES CITED}

Armstrong, R. L., and Besancon, James, 1970, A Triassic time scale dilemma; K-Ar dating of Upper Triassic mafic igneous rocks, Eastern U.S.A. and Canada and post-Upper Triassic plutons, western Idaho, U.S.A.: Eclogae Geologicae Helvetiae, v. 63, no. 1, p. 15-28.

Beck, M. E., Jr., 1972, Paleomagnetism of Upper Triassic diabase of southeastern Pennsylvania; further results: Journal of Geophysical Research, v. 77, no. 29, p. 56735687.

Bell, Henry, III, and Popenoe, Peter, 1976, Gravity studies in the Carolina slate belt near the Haile and Brewer mines, north-central South Carolina: U.S. Geological Survey Journal of Research, v. 4, no. 6, p. 667-682.

Chalcraft, R. G., 1976, The petrology of Mesozoic dolerite dikes in South Carolina: South Carolina Division of Geology Geologic Notes, v. 20, no. 2, p. 52-61.

Conley, J. F., and Bain, G. L., 1965, Geology of the Carolina slate belt west of the Deep River-Wadesboro Triassic basin, North Carolina: Southeastern Geology, v. 6, no. 3, p. 117-138.

deBoer, Jelle, 1967, Paleomagnetic-tectonic study of Mesozoic dike swarms in the Appalachians: Journal of Geophysical Research, v. 72, no. 8, p. 2237-2250.

1968, Paleomagnetic differentiation and correlation of the Late Triassic volcanic rocks in the central Appalachians (with special reference to the Connecticut Valley) : Geological Society of America Bulletin, v. 79, no. 5, p. 609-626.

Doell, R. R., and Cox, Allan, 1965, Measurement of the remanent magnetization of igneous rocks: U.S. Geological Survey Bulletin 1203-A, p. A1-A32.

Fisher, R. A., 1953, Dispersion on a sphere: Royal Society [London] Proceedings, Series A, v. 217, no. 1130, p. 295305.

Fullagar, P. D., 1971, Age and origin of plutonic intrusions in the Piedmont of the southeastern Appalachians: Geological Society of America Bulletin, v. 82, no. 10, p. 2845-2862.

Kane, M. R., Harwood, D. S., and Hatch, N. L., Jr., 1971, Continuous magnetic profiles near ground level as a means of discriminating and correlating rock units: Geo- 
logical Society of America Bulletin, v. 82, no. 9, p. 24492456.

King, P. B., 1961, Systematic pattern of Triassic dikes in the Appalachian region: U.S. Geological Survey Professional Paper 424-B, p. B93-B95.

1971, Systematic pattern of Triassic dikes in the Appalachian region-second report: U.S. Geological Survey Professional Paper 750-D, p. D84-D88.

McElhinny, M. W., 1973, Paleomagnetism and plate tectonics: Liondon, Cambridge University Press, $357 \mathrm{p}$.

McSween, H. Y., Jr., 1972, An investigation of the Dutchmans Creek Gabbro, Fairfield County, South Carolina: South Carolina Division of Geology Geologic Notes, v. 16, no. 2, p. 19-42.

May, P. R., 1971, Pattern of Triassic-Jurassic diabase dikes around the North Atlantic in the context of predrift position of the continents: Geological Society of America Bulletin, v. 82, no. 5, p. 1285-1291.

Nystrom, P. G., Jr., 1972, Geology of the Catarrah NW (Jefferson) quadrangle: Columbia, S.C., University of South Carolina, unpublished M.S. dissertation, $49 \mathrm{p}$.

Overstreet, W. C., and Bell, Henry, III, 1965a, The crystalline rocks of South Carolina: U.S. Geological Survey Bulletin $1183,126 \mathrm{p}$.

1965b, Geologic map of the crystalline rocks of South Carolina: U.S. Geological Survey Miscellaneous Geologic Investigations Map I-413, scale 1:250,000.

Popenoe, Peter, and Bell, Henry III, 1975, Simple Bouguer gravity map of part of the Carolina slate belt including the Haile and Brewer mine areas, north-central South Carolina: U.S. Geological Survey Geophysical Investigations Map GP-904, scale $1: 125,000$.

Popenoe, Peter, and Zietz, Isidore, 1977, The nature of the geophysical basement beneath the Coastal Plain of South Carolina and northeastern Georgia: U.S. Geological Survey Professional Paper 1028-I, p. 118-137.

Ragland, P. C., Rogers, J. J. W., and Justus, P. S., 1968, Origin and differentiation of Triassic dolerite magmas, North Carolina, USA: Contributions to Mineralogy and Petrology, v. 20, no. 1, p. 57-80.

Randazzo, A. F., Swe, Win, and Wheeler, W. H., 1970, A study of tectonic influence on Triassic sedimentation- the Wadesboro basin, central Piedmont: Journal of Sedimentary Petrology, v. 40, no. 3, p. 998-1006.

Randazzo, A. F., and Copeland, R. E., 1976, The geology of the northern portion of the Wadesboro Triassic basin, North Carolina: Southeastern Geology, v. 17, no. 3, p. 115-138.

Rothe, G. H., and Long, L. T., 1975, Geophysical investigation of a diabase dike swarm in west-central Georgia: Southeastern Geology, v. 17, no. 2, p. 67-79.

Secor, D. T., Jr., and Wagener, H. D., 1968, Stratigraphy, structure, and petrology of the Piedmont in central South Carolina-Carolina Geological Society Field Trip, Oct. 18-20, 1968: South Carolina Division of Geology Geologic Notes, v. 12 , no. 4 , p. 67-84.

Smith, R. C., II, Rose, A. W., and Lanning, R. M., 1975, Geology and geochemistry of Triassic diabase in Pennsylvania: Geological Society of America Bulletin, v. 86, no. 7, p. 943-955.

Smith, T. E., 1976, Paleomagnetic study of lower Mesozoic diabase dikes and sills of Connecticut and Maryland: Canadian Journal of Earth Science, v. 13, no. 4, p. 597-609.

Steele, K. F., Jr., 1971, Chemical variations parallel and perpendicular to strike in two Mesozoic dolerite dikes, North Carolina and South Carolina: Chapel Hill, N.C., University of North Carolina Ph.D. dissertation, 213 p.

Stuckey, J. L., 1958, Geologic map of North Carolina: Raleigh, North Carolina Division of Mineral Resources, scale $1: 500,000$.

U.S. Geological Survey, 1970, Aeromagnetic map of the Camden-Kershaw area, north-central South Carolina: U.S. Geological Survey open-file map, scale 1:24,000.

Waskom, J. D., and Butler, J. R., 1971, Geology and gravity of the Lilesville Granite batholith, North Carolina: Geological Society of America Bulletin, v. 82, no. 10, p. 2827-2844.

Wiegand, P. W., and Ragland, P. C., 1970, Geochemistry of Mesozoic dolerite dikes from eastern North America: Contributions to Mineralogy and Petrology, v. 29, no. 3, p. 195-214.

Zablocki, C. J., 1967, Results of some geophysical investigations in the Wood Hills area of northeastern Nevada: U.S. Geological Survey Professional Paper 575-B, p. B145-B154. 


\section{Aerial Gamma-Ray Survey in Duval, McMullen, Live Oak, and Webb Counties, Texas}

By JOSEPH S. DUVAL and KAREN A. SCHULZ

SHORTER CONTRIBUTIONS TO GEOPHYSICS, 1979

GEOLOGIGAL SURVEY PROFESSIONAL PAPER 1123-D

A presentation of aerial gamma-ray data

as apparent surface concentrations of

potassium, equivalent uranium, and

equivalent thorium

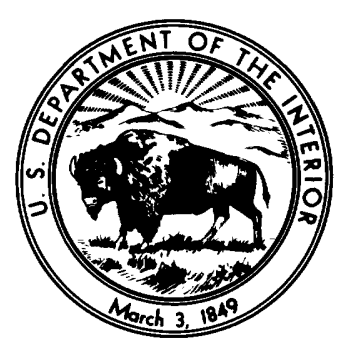





\section{CONTENTS}

Abstract
Introduction
Survey description
Geology of the surveyed area
Expected radiometric signatures
Presentation of the data
Discussion of the data
Conclusions
References cited

\section{ILLUSTRATIONS}

Figure 1. Geologic map of the area covered by the aerial survey near Freer, Tex

2. Contour maps of the apparent surface concentrations of potassium, equivalent uranium, and equivalent thorium -.....

3. Contour maps of the total count data, eU/eTh, eU/K, and $\mathrm{eTh} / \mathrm{K}$

4. Graph showing frequency distributions of the radioelement concentrations for the Oakville Sandstone ----

5. Anomaly map of $\mathrm{eU}$ and $\mathrm{eU} / \mathrm{eTh}$ anomalies where the values exceed the expected ranges

\section{TABLES}

TABLE 1. List of the energy windows used in the measurement of the radiometric data

2. Average values and indicated range of expected values of the radiometric data for the mapped geologic units 



\title{
AERIAL GAMMA-RAY SURVEY IN DUVAL, MCMULLEN, LIVE OAK, AND WEBB COUNTIES, TEXAS
}

\author{
By Joseph S. Duval and Karen A. Schulz
}

\begin{abstract}
High-sensitivity gamma-ray data have been obtained for an area of about $3300 \mathrm{~km}^{2}$ in Duval, McMullen, Live Oak, and Webb Counties, Tex. Contour maps of the aerial gammaray data show the apparent surface concentrations of the radioelements potassium, uranium, and thorium. The different geologic units within the survey area have the following average values: 1.2 percent $\mathrm{K}, 1.8 \mathrm{ppm}$ (parts per million) eU (equivalent uranium), and $5.6 \mathrm{ppm}$ eTh (equivalent thorium) for the Goliad Sand; 1.5 percent $\mathrm{K}, 1.9 \mathrm{ppm}$ $\mathrm{eU}$, and $6.5 \mathrm{ppm}$ eTh for the Oakville Sandstone; 1.5 percent $\mathrm{K}, 2.3 \mathrm{ppm} \mathrm{eU}$, and $9.7 \mathrm{ppm}$ eTh for the undivided Catahoula Tuff; 1.9 percent $\mathrm{K}, 2.9 \mathrm{ppm}$ eU, and $9.9 \mathrm{ppm}$ eTh for the Frio Clay; 1.5 percent $\mathrm{K}, 2.8 \mathrm{ppm}$ eU, and $9.7 \mathrm{ppm}$ eTh for the Jackson Group. A comparison of anomalies defined on the map of $\mathrm{eU}$ with those defined on the map of eU/eTh indicates that the ratio is the more effective function for locating areas where known mineralization occurs.
\end{abstract}

\section{INTRODUCTION}

If research is to be done to improve the interpretation and understanding of aerial gamma-ray data, high-quality data must be obtained over an area where the surface geology and mineralization occurrences are known and also where surface disturbances due to man's activities are minimal. The U.S. Geological Survey has obtained such data for an area of about $3300 \mathrm{~km}^{2}$ in south Texas.

This paper presents those data in terms of apparent surface concentrations of the radioelements potassium, uranium, and thorium, and the data are discussed relative to the known lithology. Use of the data to detect areas of known mineralization is also discussed.

\section{SURVEY DESCRIPTION}

The data presented are from a survey flown for the U.S. Geological Survey by Geodata International,

\footnotetext{
1 Any use of trade names in this publication is for descriptive purposes only and does not constitute endorsement by the U.S. Geological Survey.
}

Inc. ${ }^{1}$, in Duval, McMullen, Live Oak, and Webb Counties, Tex., near Freer, Tex. (fig. 1).

High-sensitivity aeroradiometric data were obtained continuously along flight lines spaced at $1.6-\mathrm{km}$ intervals. The flight lines were oriented northwest-southeast at an angle of about $34^{\circ}$ west of north. Fifty-two lines each $40 \mathrm{~km}$ long were flown; resulting in 2,080 line-kilometers of data. The nominal altitude of the aircraft during the survey was $120 \mathrm{~m}$ above the ground surface.

The radiometric data were measured using eight $\mathrm{NaI}(\mathrm{Tl})$ (thallium-activated sodium iodide) detectors. The detectors were right cylinders $29.2 \mathrm{~cm}$ in diameter and $10.2 \mathrm{~cm}$ thick, and the total detector volume was $54.4 \mathrm{~L}$. An additional $\mathrm{NaI}(\mathrm{TI})$ detector (with the same dimensions as the other eight detectors) was shielded from the ground radiation by about $10 \mathrm{~cm}$ of lead. This detector was used to monitor $\mathrm{Bi}^{214}$ in the atmosphere. A radar altimeter was used to measure the altitude of the aircraft above the ground surface. The aircraft location was determined from the output of a doppler radar navigation system, and a cross check was provided by a $35-\mathrm{mm}$ film with pictures of the ground below the aircraft. One picture was taken every 3 seconds, and at the nominal airspeed of $192 \mathrm{~km} / \mathrm{h}$, each picture had a 15 to 20 percent overlap of both the previous and succeeding pictures.

Various corrections were applied to the data. Background counts due to cosmic rays, aircraft contamination, and airborne $\mathrm{Bi}^{214}$ were subtracted from the observed radiometric count rates. The counts due to cosmic rays were determined by monitoring the gamma-ray spectrum from $3.0 \mathrm{MeV}$ (million electron volts) to $6.0 \mathrm{MeV}$. The aircraft contamination was measured by flying at altitudes higher than $1,000 \mathrm{~m}$, where radiation from the ground is negligible. The 

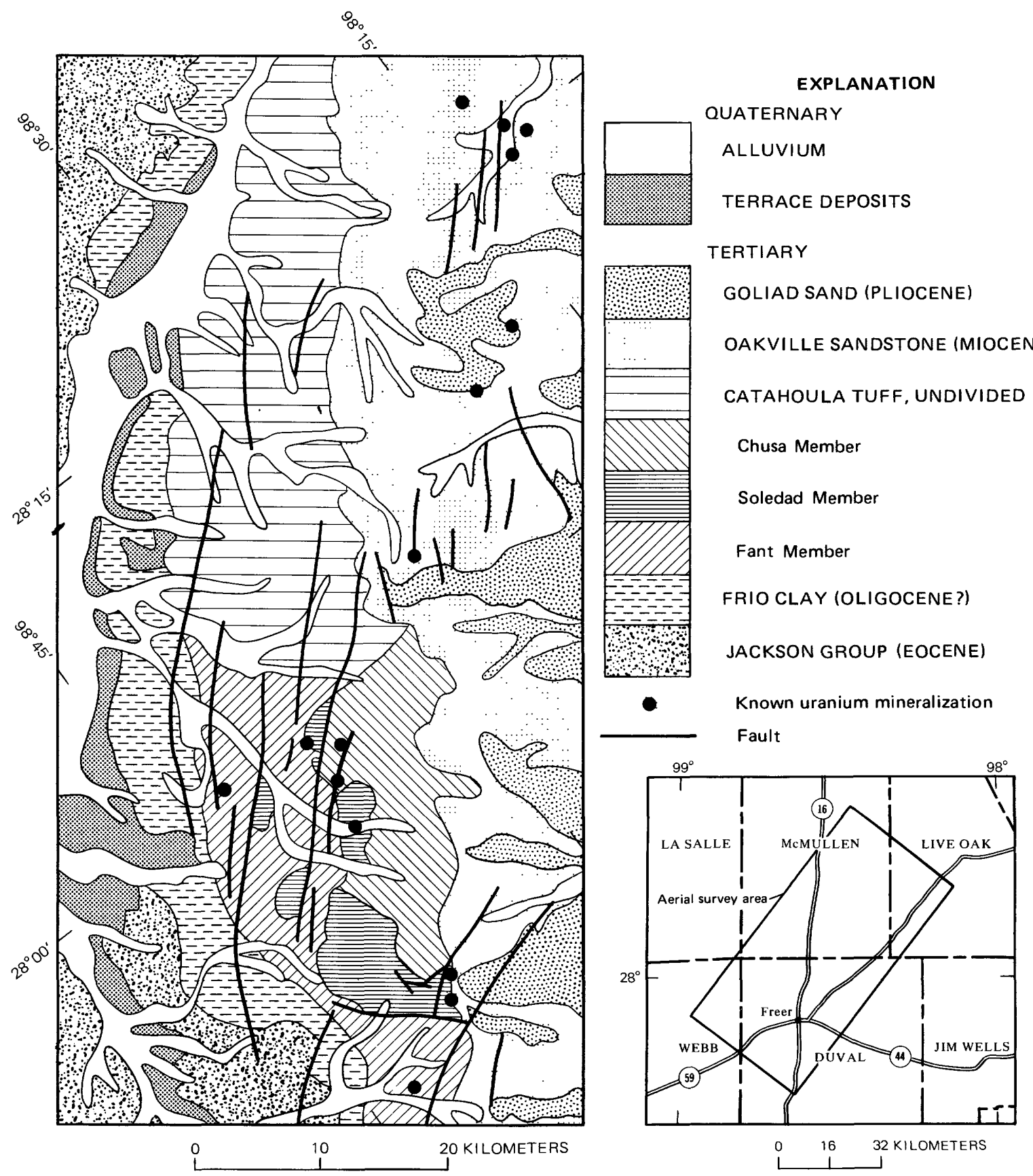

FIGURE 1.-Geologic map of the area covered by the aerial survey near Freer, Tex.

airborne $\mathrm{Bi}^{214}$ was measured by the shielded detector. The radiometric data were also adjusted to a common altitude of $122 \mathrm{~m}$ using a standard equation for the exponential attenuation of gamma rays. The corrections for Compton scattered gamma rays in the potassium and equivalent uranium (eU) energy windows were the final corrections applied to the radiometric data. Table 1 lists the radioelements (potassium, equivalent uranium, and equivalent thorium) and the energy windows that were used to obtain the count rates that are proportional to the concentrations of the elements. Two energy windows were used to measure eU. The second, lower, energy window, which includes the $1.12 \mathrm{MeV}$ gamma ray of $\mathrm{Bi}^{214}$, increases the net eU count rate by a factor approximately equal to 2.8 times the count rate obtained with the higher energy window alone. The total count window is also listed in table 1. 
TABLE 1.-List of the energy windows used in the measurement of the radiometric data

Element Energy window (MeV)
$\mathrm{K}$ - - - - - - - 1.34-1.65

$\mathrm{eU}$ - _ _ _ _ - 1.07-1.33

$\mathrm{eU}$ - _ _ _ _ - - 1.66-2.42

eTh - _ - - - - 2.44-2.81

Total count - - - - . 40-3

GEOLOGY OF THE SURVEYED AREA

The survey was flown over the surface exposures of a sequence of Texas Gulf Coast Tertiary rocks ranging from the Pliocene Goliad Sand to the Eocene Jackson Group. The stratigraphy from youngest to oldest, as given by Eargle, Dickinson, and Davis (1975), is as follows :

\section{Pliocene :}

Goliad Sand :

Sandstone, light-gray, calichified, fine- to medium-grained in upper part, medium- to coarse-grained near base; and pink, calcareous clay.

Miocene :

Fleming Formation :

Claystone and minor sandstone, gray, pink, red, and light-brown; red color increases upward in unit.

Oakville Sandstone:

Sandstone, gray to light-reddish-brown, fine- to coarse-grained; contains clay pebbles, silt, clay, and calcite cement.

Catahoula Tuff :

Chusa Member:

Claystone, pink, calcareous, tuffaceous, montmorillonitic; and a basal sandy conglomerate containing pebbles of volcanic rock, siliceous limestone, and sandstone.

Soledad Member :

Conglomerate, sandy volcanic; contains boulders of amygdaloidal rhyolite, trachyte, and trachyandesite as large as $30 \mathrm{~cm}$ in diameter.

Fant Member:

Tuff, white to light-gray, zeolitic, montmorillonitic; and interbedded sandstone.
Oligocene ( ?) :

Frio Clay :

Clay, light-gray to green, montmorillonitic, zeolitic, tuffaceous; and channel-sandstone beds.

Eocene (upper) :

Whitsett Formation (of Jackson Group) :

Fashing Clay Member:

Clay and tuff, gray, calcareous, montmorillonitic, zeolitic, fossiliferous; and some beds of lignite, coquina, and sandstone.

Callihan Sandstone Member (Ataslosa County) and its approximate equivalent the Tordilla Sandstone Member of the Whitsett in Karnes County :

Sandstone, yellowish-gray, fine-grained, arkosic, tuffaceous, fossiliferous.

Dubose Member :

Clay and siltstone, gray, montmorillonitic, tuffaceous; and minor amounts of sandstone and lignite.

Deweesville Sandstone Member:

Sandstone, gray, fine-grained, arkosic, crossbedded; contains burrows of Ophiomorpha sp. and root impressions and a few beds of fossiliferous siltstone and claystone.

Conquista Clay Member:

Mudstone, gray, tuffaceous, montmorillonitic, fossiliferous, opalitic, zeolitic, carbonaceous; and a few thin beds of fine-grained arkosic sandstone.

Dilworth Sandstone Member:

Sandstone, light-gray, very fine to mediumgrained, arkosic, crossbedded to weakly laminated; contains burrows of Ophiomorpha sp. and root impressions.

The geologic map shown on figure 1 was adapted from the Laredo and Crystal City Atlas Sheets of the Texas Bureau of Economic Geology, Austin, Tex. (1976). If the Fleming Formation is present in the survey area, it has not been recognized as a separate unit on the Atlas Sheets.

\section{EXPECTED RADIOMETRIC SIGNATURES}

Because lithologically different materials have both physical and chemical differences, prediction of the relative radioactivity levels and the expected concentrations of potassium, uranium, and thorium should be possible, given typical values for rocks having similar lithologies. Duex (1971) gives average values for the exposed Catahoula Tuff as 1.1 percent $\mathrm{K}, 3.1 \mathrm{ppm}$ (parts per million) eU, and $9.4 \mathrm{ppm}$ eTh 

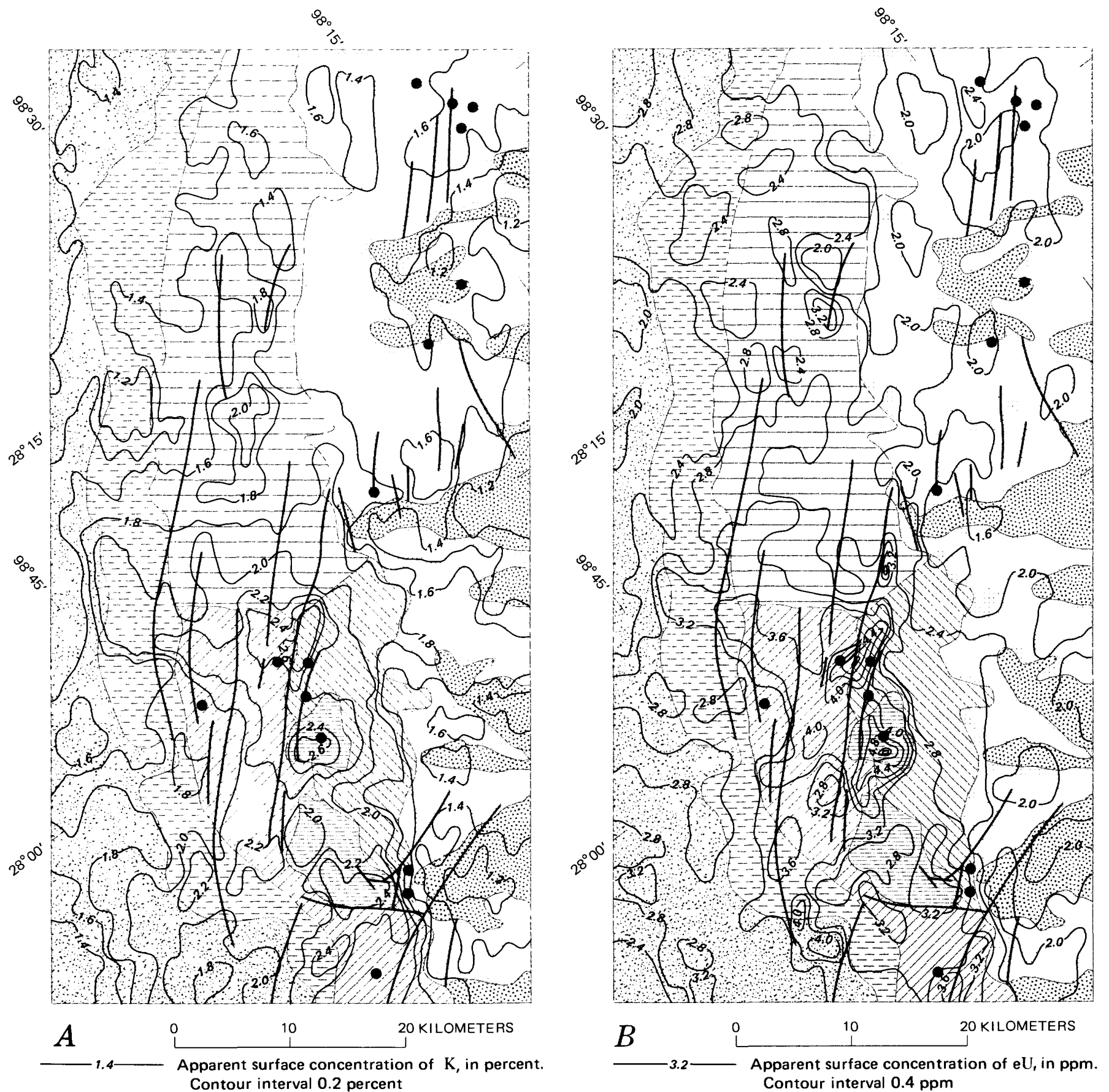

Figure 2.-Contour maps of the apparent surface concentrations of $A$, potassium; $B$, Equivalent uranium; $C$, Equivalent thorium.

(equivalent thorium). Duval and others (1972) give concentrations of 0.6 percent $\mathrm{K}, 1.1 \mathrm{ppm} \mathrm{eU}$, and $2.9 \mathrm{ppm}$ eTh for a sandstone in the area of the Llano Uplift in central Texas.

Because the Frio Clay, the Catahoula Tuff (excepting the Soledad Member), and the upper members of the Whitsett Formation are lithologically similar, in that they are of volcanic origin and are tuffaceous, they can be expected to have similar radiometric signatures. Inherent in the preceding statement are the assumptions that the original average concentrations of the radioelements in the sediments did not differ by more than a few parts per million and that all the sedimentary rocks have undergone similar weathering. In the Soledad Member, the concentrations of potassium and uranium should be higher than those in the other volcanic sedimentary rocks, because weathering processes 


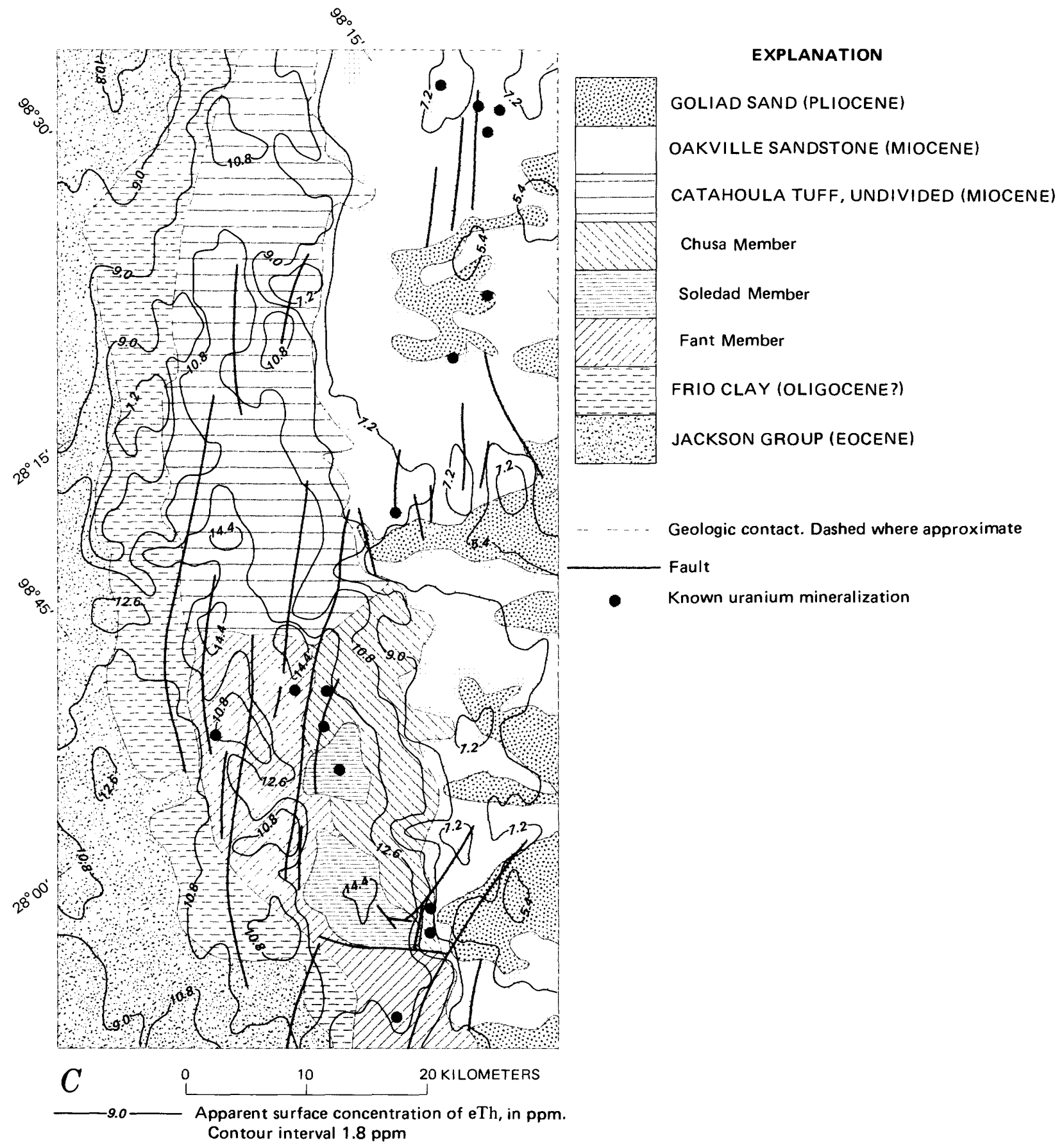

Figure 2.-(For caption, see facing page.)

should be less effective in leaching potassium and uranium from the conglomerate than from the tuffaceous sedimentary rocks.

Because the Oakville Sandstone and the Goliad Sand are sandstones of continental origin, they might be expected to have radioelement concentrations similar to those of sandstone of continental origin stuied by Duval and others (1972). If the source rocks for the sandstones are very different or if differences in weathering exist, this assumption will not hold true. The Oakville and Goliad should have similar radioelement concentrations, and they should have lower concentrations than any of the volcanic sedimentary rocks.

\section{PRESENTATION OF THE DATA}

The data from the aerial survey are presented in the form of contour maps in figures 2 and 3 . These 

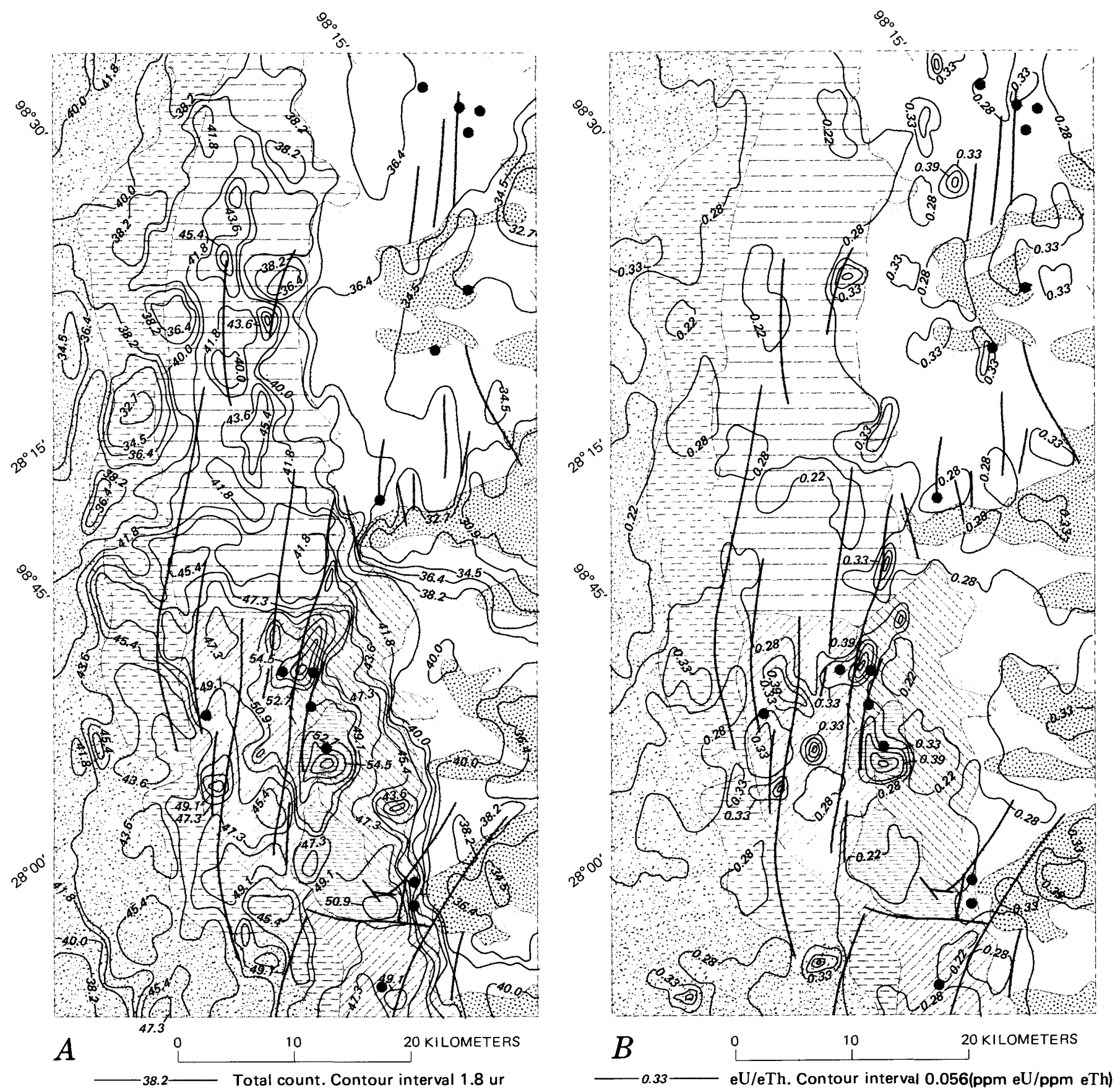

Figure 3.-Contour maps of $A$, The total count data; $B, \mathrm{eU} / \mathrm{eTh} ; C, \mathrm{eU} / \mathrm{K} ; D, \mathrm{eTh} / \mathrm{K}$.

maps were adapted from maps produced by an automatic contouring computer program. The fully corrected count-rate data were converted to represent the apparent surface concentrations of $K$, in percent, $\mathrm{eU}$, in parts per million, and $\mathrm{eTh}$, in parts per million (fig. 2), using the calibration constants given by Duval, Schultz, and Pitkin (1977). The units used for the total-count map (fig. $3 A$ ) are defined such that 1 ur (radioelement unit, International Atomic Energy Agency, 1976) is equal to the total count that would be measured by a detector being carried at an altitude of $122 \mathrm{~m}$ over a broad source of gamma rays that has an apparent surface concentration of $1 \mathrm{ppm}$ eU but lacks potassium and thorium. The value of $1 \mathrm{ur}=55 \mathrm{cps}$ (counts per second) adopted for this aerial survey was determined by using a linear regression fit to establish the relationship between the total count and the radioelement concentrations. 

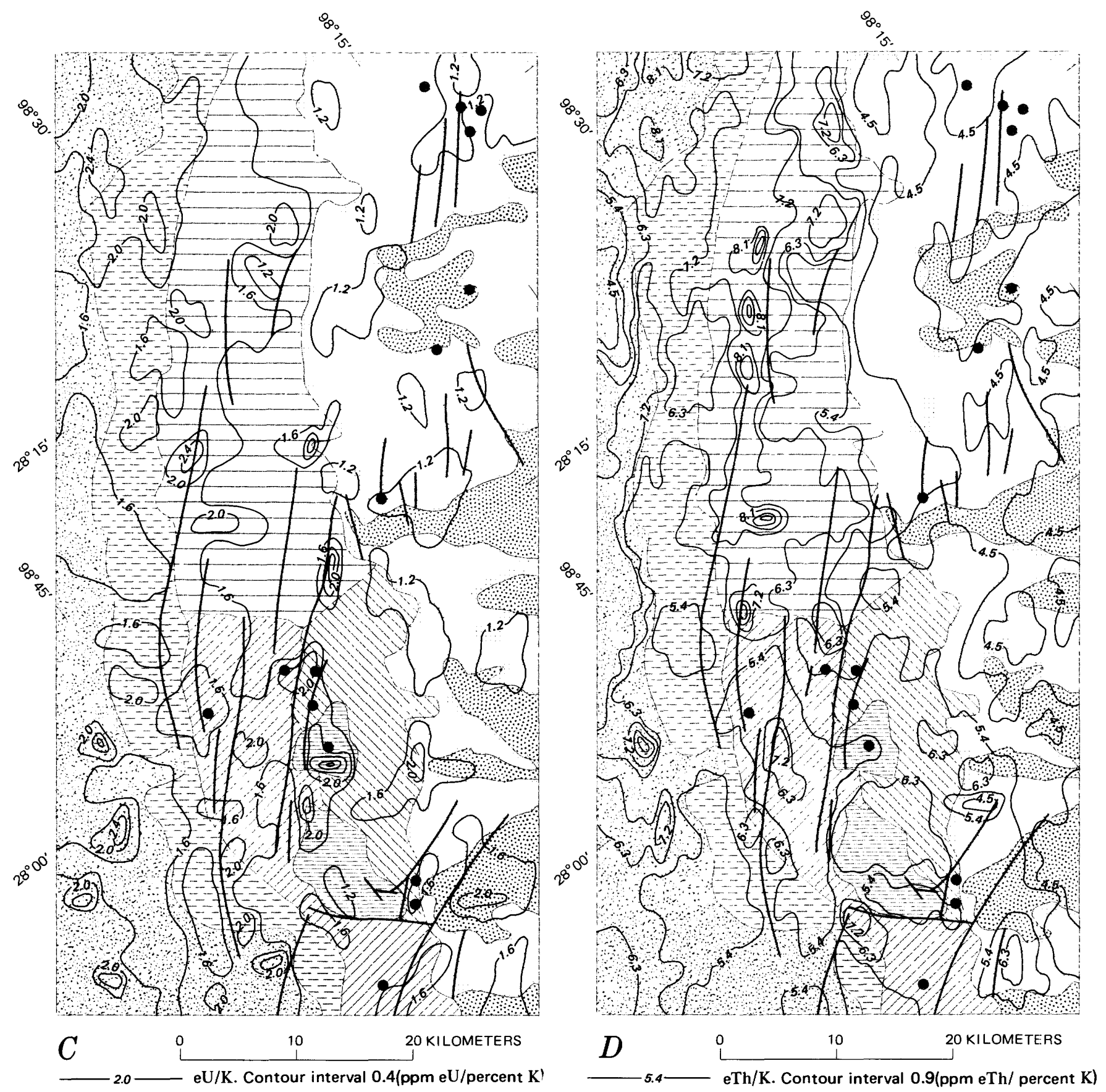

EXPLANATION

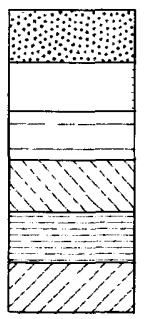

GOLIAD SAND (PLIOCENE)

OAKVILLE SANDSTONE (MIOCENE)

CATAHOULA TUFF, UNDIVIDED (MIOCENE)

Chusa Member

Soledad Member

Fant Member

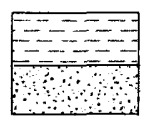

FRIO CLAY (OLIGOCENE?)

JACKSON GROUP (EOCENE)

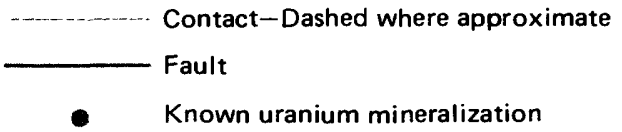

Frgure 3.-(For caption, see facing page.) 


\section{DISGUSSION OF THE DATA}

Before the data can be discussed relative to the mapped geology, the normal or expected values for each geologic unit must be determined. Because geologic formations are not necessarily uniform in radioactivity, calculations of mean values and of standard deviations can be in error. A better method to determine the average value for a unit is to plot a frequency distribution of the number of data points with a given value versus the value. Figure 4 shows the frequency distributions of the radioelement concentrations for the Oakville Sandstone.

Once the frequency distributions have been plotted, the expected values for each geologic unit can be defined either by fitting a mathematical function, such as a normal distribution, to the curves or by visual inspection. Table 2 lists the average values of the radiometric data for each geologic unit plus or minus a value representative of the normal range of values. The average values were determined by inspection of the frequency distribution curves. The plus or minus deviation from the mean value was defined as 0.75 times the full width of the curve at one-half of the peak number of data points. The values given for the Oakville Sandstone are shown in figure 4.

As expected, the radioactive characteristics (particularly eU, eTh, and eTh/K of fig. $3 D$ ) of the Goliad and the Oakville are significantly different from those of the more tuffaceous sediments; however, the concentrations given by Duval and others (1972) for the sandstone in central Texas are also significantly different. This difference suggests that care must be taken to avoid classifying geologic units on the basis of such physical parameters as grain size when the purpose of the classification is to predict expected radioelement concentrations.

The differences between the Goliad and the Oakville are subtle, and the values given in table 2 could not be used to distinguish them. However, the contour maps indicate that some of the mapped Goliad has lower values for $\mathrm{K}$, eTh, and total count. This fact could provide aid for geologic mapping.

The differences among the Catahoula, Frio, and Jackson sedimentary rocks are also subtle; the greatest differences are in $\mathrm{eTh}$, total count, and eU/eTh.
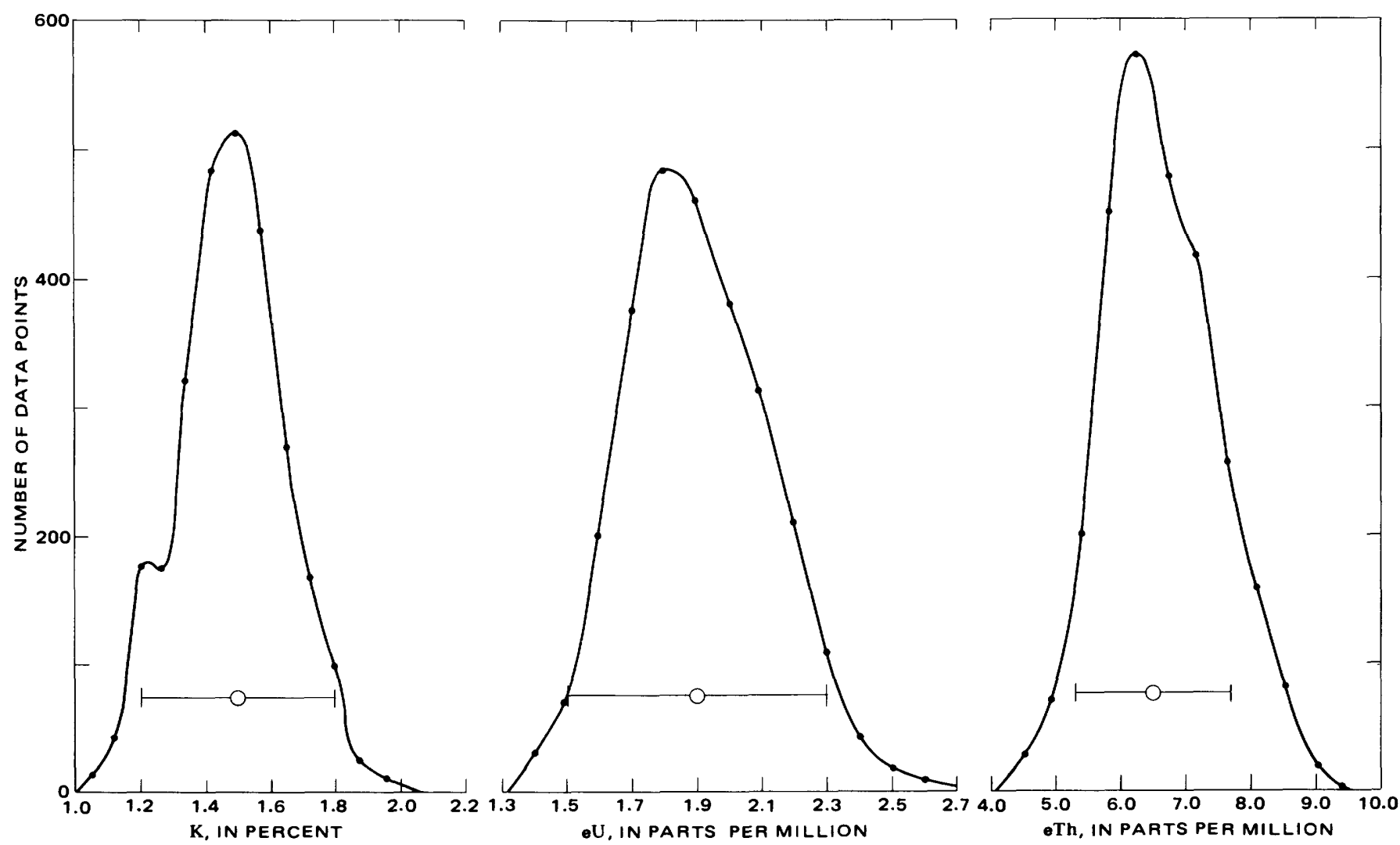

Figure 4.-Frequency distributions of the radioelement concentrations for the Oakville Sandstone. The mean value is represented by the open circle; the expected range of values, by the bar. 
AERIAL GAMMA-RAY SURVEY; DUVAL, MCMULLEN, LIVE OAK, WEBB COUNTIES, TEXAS

TABLE 2.-Average values and indicated range of expected values of the radiometric data for the mapped geologic units

\begin{tabular}{|c|c|c|c|c|c|c|c|}
\hline Geologic unit & $\begin{array}{c}\mathrm{K} \\
(\text { percent })\end{array}$ & $\begin{array}{c}\mathrm{eU} \\
(\mathrm{ppm})\end{array}$ & $\begin{array}{c}\text { eTh } \\
(\mathrm{ppm})\end{array}$ & $\begin{array}{c}\text { Total } \\
\text { count (ur) }\end{array}$ & $\mathrm{eU} / \mathrm{eTh}$ & $\mathrm{eU} / \mathrm{K}$ & $\mathrm{eTh} / \mathrm{K}$ \\
\hline $\begin{array}{l}\text { Goliad Sand } \\
\text { Oakville }\end{array}$ & $-1 \cdot 2 \pm 0.3$ & $1.8 \pm 0.4$ & $5.6 \pm 1.7$ & $32.8 \pm 6.8$ & $0.31 \pm 0.09$ & $1.4 \pm 0.5$ & $3.3 \pm 0.8$ \\
\hline $\begin{array}{l}\text { Sandstone } \\
\text { Catahoula Tuff }\end{array}$ & $-1.5 \pm 0.3$ & $1.9 \pm 0.4$ & $6.5 \pm 1.2$ & $35.4 \pm 2.7$ & $0.27 \pm 0.07$ & $1.2 \pm 0.3$ & $3.3 \pm 0.8$ \\
\hline (undivided) & $1.5+0.4$ & $2.3 \pm 0.8$ & $9.7 \pm 3.0$ & $28.2 \pm 6.8$ & $0.23 \pm 0.06$ & $1.4 \pm 0.6$ & $4 \cdot 9 \pm 1 \cdot 3$ \\
\hline Chusa $^{l}$ & $-2.0 \pm 0.3$ & $2.7 \pm 0.9$ & $11.9 \pm 2.7$ & $45.5 \pm 4.1$ & $0.22 \pm 0.07$ & $1.4 \overline{+0} .4$ & $4.6 \pm 0.8$ \\
\hline Soledad ${ }^{l}$ & $-1.2 \pm 0.5$ & $2.8 \pm 0.6$ & $12.8 \pm 1.9$ & $47.3 \pm 4.1$ & $0.22 \pm 0.09$ & $1.3 \pm 0.3$ & $4.0 \pm 1.3$ \\
\hline Fant $^{1}$ & $2.0 \pm 0.3$ & $3.3 \pm 0.6$ & $11.7 \pm 2.7$ & $38.2 \pm 6.4$ & $0.25 \pm 0.10$ & $1.5 \pm 0.5$ & $4 \cdot 1 \pm 1 \cdot 0$ \\
\hline Frio Clay & $-1.9 \pm 0.6$ & $2.9 \pm 0.7$ & $9.9 \pm 2.7$ & $35.5 \pm 7.0$ & $0.28 \pm 0.08$ & $1.4+0.6$ & $4.0 \pm 0.7$ \\
\hline Jackson Group - & $1.5 \pm 0.7$ & $2.8 \pm 0.9$ & $9.7 \pm 2.4$ & $30.0 \pm 8.9$ & $0.28 \pm 0.07$ & $1.7 \pm 0.8$ & $4.7 \pm 2.2$ \\
\hline
\end{tabular}

${ }^{1}$ Member of Catahoula Tuff.

The Catahoula in the northeastern part of the survey area, where it is undivided, has values of $\mathrm{K}, \mathrm{eU}$, eTh, and total count that are significantly lower than the values of the divided members of the Catahoula in the southwestern part of the survey area. Also, the undivided Catahoula can be more readily distinguished from the divided Catahoula than can either the Frio or the Jackson. This difference within the Catahoula suggests a facies change, and such a change would reflect a difference in the depositional environment. Galloway and others (1977) show a channel facies that correlates at least in part with the area of the divided Catahoula and a floodplain facies that correlates with the undivided Catahoula.

Another difference between the Catahoula and the other sedimentary rocks is that the eU/eTh is significantly lower in the Catahoula (fig. $3 B$ ). The lower eU/eTh could be indicative of a greater relative leaching of uranium from the Catahoula. Moxham (1964) and Duex (1971) suggest that uranium has been leached from the Catahoula sedimentary rocks, and Galloway and others (1977) have analytical data that support a hypothesis that extensive leaching of the uranium occurred soon after the sediments were deposited.

Although the differences among the radiometric characteristics are interesting and useful for geologic mapping, they do not provide any direct indicators for specific areas of uranium mineralization. The values in table 2 can, however, be used to define anomalous radiometric values. Figure 5 shows eU and $\mathrm{eU} / \mathrm{eTh}$ anomalies mapped as areas where the measured values exceed the maximum expected values, as given in table 2 . Figure 5 also shows generalized locations of known uranium mineralization. An examination of figure 5 shows that most of the known mineralized areas occur within $10 \mathrm{~km}$ of a $\mathrm{eU} / \mathrm{eTh}$ anomaly. The mineralized areas coincide reasonably well with eU anomalies within the Catahoula; however, there are no eU anomalies within the Oakville.

\section{CONGLUSIONS}

Relative radioactivity levels for a sequence of sediments can be predicted using the lithologic descriptions; however, the absolute concentration levels cannot be accurately estimated at present. More accurate estimates of the concentration levels would require knowledge of the mineral assemblage in the sediment and better information on known concentrations in similar sediments. In order to establish a table of known concentrations in similar sediments, a classification scheme will be necessary. Such a classification scheme should only use characteristics that are directly related to chemical or mineralogical properties.

Almost all sedimentary rocks, particularly those fluvial in origin, have facies changes' along strike that can have distinctive radiometric characteristics, as is true of the differences between the channel facies and the floodplain facies in the Catahoula Tuff. The possibility that similar differences may occur within other sedimentary rocks raises doubt 


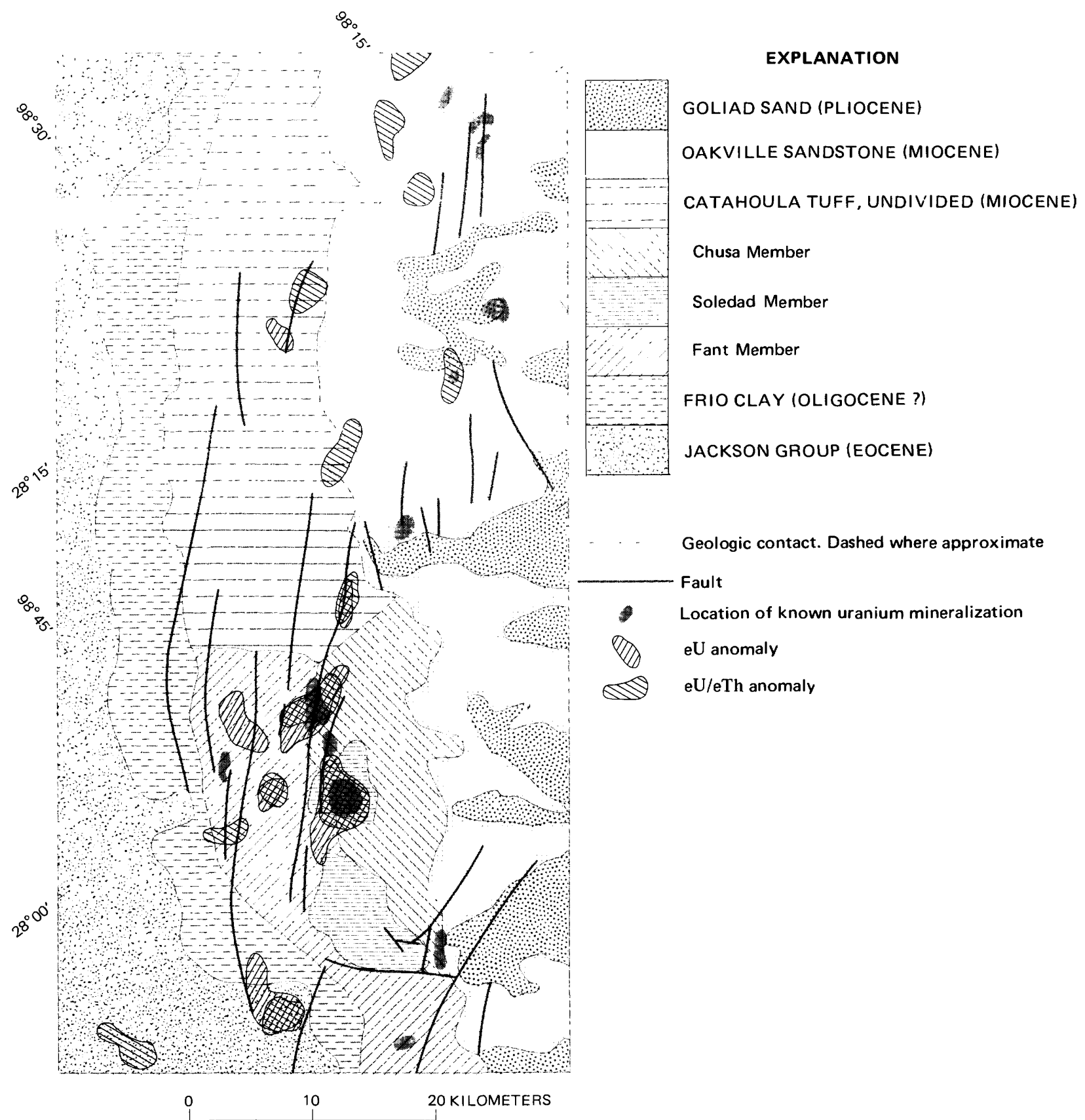

FIgURE 5.- eU and eU/eTh anomalies where the values exceed the expected ranges.

concerning the validity of expressing radiometric characteristics in terms of mapped geologic formations.

One approach that would eliminate the limitations imposed by displaying the data in terms of mapped geology is to define radiometric map units. A radiometric unit should have relatively homogeneous radioactive characteristics and be geographically continuous. Duval (1976) presents a method utilizing factor analysis that might be used to define radiometric units, and Duval, Pitkin, and Macke (1977) present a method using color images, which also might be used. However, both of the cited methods appear to require further development, and such questions as the definition of relative homogeneity must be resolved.

If the concept of radiometric anomalies is to be applied to aerial gamma-ray data, normal expected values should be defined using frequency histograms of the values measured over mapped geologic units 
or radiometric units. The application of the anomaly concept to the $\mathrm{eU}$ and $\mathrm{eU} / \mathrm{eTh}$ (fig. $3 C$ ) data presented here indicates that within the Catahoula Tuff, both $\mathrm{eU}$ and $\mathrm{eU} / \mathrm{eTh}$ are useful as indicators of uranium mineralization; however, within the Oakville Sandstone only eU/eTh provides some indication of uranium mineralization.

\section{REFERENCES CITED}

Duex, T. W., 1971, K/Ar age dates and U, K geochemistry of the Gueydan (Catahoula) formation of south Texas, Final Report: U.S. Atomic Energy Commission research contract AT (05-1) -935, p. 101-145.

Duval, J. S., 1976, Statistical interpretation of airborne gamma-ray spectrometric data using factor analysis, in International Atomic Energy Agency, Exploration for uranium ore deposits-a symposium: International Atomic Energy Agency, IAEA-SM-208, p. 71-80.

Duval, J. S., Pitkin, J. A., and Macke, D. L., 1977, Composite images of radiometric data from south Texas and Wyoming, in U.S. Geological Survey, Short papers of the U.S. Geological Survey uranium-thorium symposium: U.S. Geological Survey Circular 753, p. 21-22.

Duval, J. S., Schulz, K. A., and Pitkin, J. A., 1977, Calibration constants for the Geodata International, Inc., and Texas Instruments, Inc., high sensitivity systems used for the ERDA aerial gamma-ray surveys: U.S. Geological Survey Open-File Report 77-159, $15 \mathrm{p}$.

Duval, J. S., Worden, J. M., Clark, R. B., and Adams, J. A. S., 1972, Experimental comparison of $\mathrm{NaI}(\mathrm{Tl})$ and solid organic scintillation detectors for use in remote sensing of terrestrial gamma rays: Geophysics, v. 37, no. 5, p. 879-888.

Eargle, D. H., Dickerson, K. A., and Davis, B. O., 1975, South Texas uranium deposits: American Association of Petroleum Geologists Bulletin, v. 59, no. 5, p. 766-779.

Galloway, W. E., Murphy, T. D., Belcher, R. C., Johnson, B. D., and Sutton, S., 1977, Catahoula Formation of the Texas coastal plain; depositional systems, composition, structural development, ground-water flow history, and uranium distribution: Texas University Bureau of Economic Geology Report of Investigations 87, 63 p.

International Atomic Energy Agency, 1976, Radiometric reporting methods and calibration in uranium exploration: International Atomic Energy Agency Technical Report Series $174,57 \mathrm{p}$.

Moxham, R. M., 1964, Radioelement dispersion in a sedimentary environment and its effect on uranium exploration: Economic Geology, v. 59, no. 2, p. 309-321.

Texas University Bureau of Economic Geology, 1976, Crystal City-Eagle Pass Sheet: Geologic Atlas of Texas, scale $1: 250,000$.

1976, Laredo Sheet: Geologic Atlas of Texas, scale $1: 250,000$. 